Victor Dias Lopes

\title{
Proposta de integração entre tecnologias adaptativas e algoritmos genéticos
}

\author{
Dissertação apresentada à Escola Po- \\ litécnica da Universidade de São Paulo \\ para obtenção do Título de Mestre em \\ Engenharia.
}


Victor Dias Lopes

\title{
Proposta de integração entre tecnologias adaptativas e algoritmos genéticos
}

\author{
Dissertação apresentada à Escola Po- \\ litécnica da Universidade de São Paulo \\ para obtenção do Título de Mestre em \\ Engenharia.
}

Área de concentração:

Sistemas Digitais

Orientador:

Prof. Dr. Ricardo Luis de Azevedo da Rocha 
Este exemplar foi revisado e alterado em relação à versão original, sob responsabilidade única do autor e com a anuência de seu orientador.

São Paulo, ... de ... de 200...

Assinatura do autor

Assinatura do orientador

\section{Ficha Catalográfica}

Lopes, Victor Dias

Proposta de integração entre tecnologias adaptativas e algoritmos genéticos. São Paulo, 2009. 110 p.

Dissertação (Mestrado) — Escola Politécnica da Universidade de São Paulo. Departamento de Engenharia de Computação e Sistemas Digitais.

1. Algoritmos genéticos 2. Inteligência artificial 3. Teoria da computação 4. Teoria dos autômatos I. Universidade de São Paulo. Escola Politécnica. Departamento de Engenharia de Computação e Sistemas Digitais II. t. 


\section{Resumo}

Este trabalho é um estudo inicial sobre a integração de duas áreas da engenharia da computação, as tecnologias adaptativas e os algoritmos genéticos. Para tanto, foi realizada a aplicação de algoritmos genéticos na inferência de autômatos adaptativos. Várias técnicas foram estudas e propostas para a implementação do algoritmo, visando à obtenção de resultados cada vez mais satisfatórios.

Ambas as tecnologias, algoritmos genéticos e tecnologia adaptativa, possuem caráter fortemente adaptativo, porém com características bastante diferentes na forma que são implementadas e executadas.

As inferências, propostas neste trabalho, foram realizadas com sucesso, de maneira que as técnicas descritas podem ser empregadas em ferramentas de auxílio para projetistas desses tipos de dispositivos. Ferramentas que podem vir a ser úteis devido à complexidade envolvida no desenvolvimento de um autômato adaptativo.

Através desta aplicação dos algoritmos genéticos, observando como os autômatos evoluíram durante a execução dos ensaios realizados, acredita-se que foi obtido um entendimento melhor da estrutura e funcionamento dos autômatos adaptativos e de como essas duas tecnologias, tão importantes, podem ser combinadas. 


\section{Abstract}

This work is an initial study about the integration of two computing engineering areas, the adaptive technologies and the genetic algorithms. For that, it was performed the application of genetic algorithms for the adaptive automata inference. Several techniques were studied and proposed along the algorithm implementation, always seeking for more satisfying results.

Both technologies, genetic algorithm and adaptive technology, hold very strong adaptive features, however, with very different characteristics in the way they are implemented and executed.

The inferences, proposed in this work, were performed with success, so that the techniques described may be employed in aid tools for designers of such devices. Tools that may be useful due to the complexity involved in the development of an adaptive automaton.

Through this genetic algorithm application, observing how automata evolved during the algorithm execution, we believe that it was obtained a better understanding about the adaptive automaton structure and how those two, so important, technologies can be integrated. 


\title{
Sumário
}

\section{Lista de Figuras}

\author{
Lista de Tabelas
}

\section{Introdução}

1 Introdução 2

1.1 Apresentação . . . . . . . . . . . . . . . . . . 2

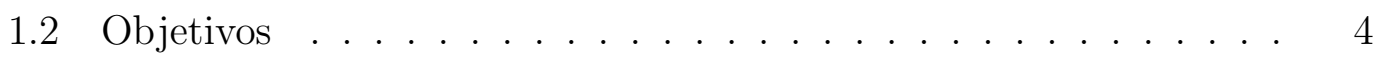

1.2.1 Algoritmos genéticos na inferência de autômatos finitos . . 4

1.2.2 Relação de dominância dinâmica em genomas diplóides . . 5

1.2.3 Algoritmos genéticos para a inferência de autômatos adaptativos ....................... 5

1.2.4 Nova camada adaptativa para autômatos adaptativos . . . 6

1.2.5 A arquitetura Darwin . . . . . . . . . . . 6

1.3 Estrutura ......................... 6

II Fundamentos teóricos 8

$\begin{array}{lll}2 & \text { Alfabetos, cadeias e linguagens } & 10\end{array}$

2.1 Representação de linguagens . . . . . . . . . . . . . . . . . . . 11

2.2 Expressões regulares . . . . . . . . . . . . . . . . . 11

2.3 Gramáticas . . . . . . . . . . . . . . . . . . . 12

2.4 Autômatos de estados finitos determinísticos . . . . . . . . . . . . 14 
3.1 Dispositivo subjacente . . . . . . . . . . . . . . 16

3.2 Camada Adaptativa . . . . . . . . . . . . . . . 17

3.2.1 Funções adaptativas . . . . . . . . . . . . . . . . 18

3.3 Autômatos adaptativos . . . . . . . . . . . . . . . . . 20

3.4 Hierarquia de linguagens . . . . . . . . . . . . . . . . 21

4 Algoritmos de busca $\quad 23$

4.1 Algoritmos de busca e otimização . . . . . . . . . . . . . . . 23

4.1 Hiperespaço . . . . . . . . . . . . . . . . . 23

4.1 .2 Adequação . . . . . . . . . . . . . . . . . . . . . 24

4.1 .3 Convergência . . . . . . . . . . . . . . . . 24

4.1 .4 Ótimos globais e locais . . . . . . . . . . . . 24

4.1.5 Critério de parada . . . . . . . . . . . . 25

4.2 Algoritmos de busca convencionais . . . . . . . . . . . . 26

4.2 .1 Hill climbing . . . . . . . . . . . . . . . . . . 26

4.2.2 Simulated Annealing . . . . . . . . . . . . . . 27

4.3 Computação Evolutiva . . . . . . . . . . . . . . . . 28

5 Algoritmos Genéticos $\quad 30$

5.1 Ambiente ............................ 31

5.2 Genoma .............................. 31

5.3 Geração . . . . . . . . . . . . . . . . . . . . . . 32

5.3 .1 Geração inicial . . . . . . . . . . . . . . . . 32

5.4 Operações Genéticas . . . . . . . . . . . . . . . . . 33

5.4.1 Crossover de ponto único . . . . . . . . . . . . . 33

5.4.2 Crossover com dois pontos . . . . . . . . . . 33

5.4.3 Crossover com múltiplos pontos . . . . . . . . . . 34

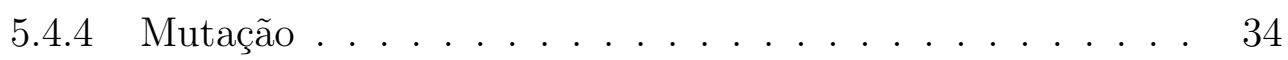


5.4 .5 Mutação Heurística . . . . . . . . . . . . . . . . . . . . 34

5.4 .6 Inversão . . . . . . . . . . . . . . . . . . 35

5.5 Incesto . . . . . . . . . . . . . . . . 35

5.6 Avaliação dos indivíduos . . . . . . . . . . . . . . . . 35

5.7 Seleção dos indivíduos . . . . . . . . . . . . . . . . . 36

5.7 .1 Roulette-wheel . . . . . . . . . . . . . 36

5.8 Teorema de Schema . . . . . . . . . . . . . . . . . . . . . . 38

5.9 Critério de parada . . . . . . . . . . . . . . . . . 39

5.10 Relação de dominância dinâmica . . . . . . . . . . . . . . . 40

5.11 Coevolução . . . . . . . . . . . . . . . . . . . . . 4 41

5.12 Calibração . . . . . . . . . . . . . . . . . . . . 4 42

\section{Implementação $\quad 44$}

$\begin{array}{lll}6 & \text { Propostas } & 46\end{array}$

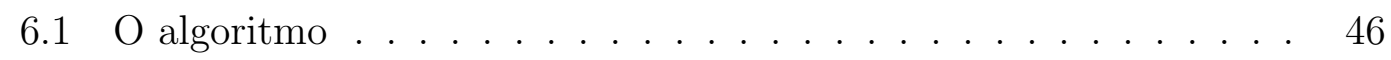

6.1.1 Representação do cromossomo para a inferência de autômatos finitos .................... . . . 47

6.1.2 Representação do cromossomo para a inferência de autômatos adaptativos . . . . . . . . . . . . . . . . 49

6.1 .3 Inicialização da população . . . . . . . . . . . . . 55

6.1.4 Geração de cadeias . . . . . . . . . . . . . . 55

6.1 .5 Coevolução . . . . . . . . . . . . . . . . 57

6.1 .6 Seleção . . . . . . . . . . . . . . . . . . 59

6.1 .7 Avaliação das soluções . . . . . . . . . . . . . . . . 61

6.1.8 Contra-exemplo ................... 64

6.1.9 Relação de dominância dinâmica . . . . . . . . . . . 67

6.1 .10 Fluxo dos operadores genéticos . . . . . . . . . 69

6.1 .11 Critério de parada . . . . . . . . . . . . . 71 
6.2 Nova camada adaptativa . . . . . . . . . . . . . . . . . 71

$\begin{array}{lll}7 & \text { A implementação } & 74\end{array}$

7.1 O processo de software . . . . . . . . . . . . . . . . 74

7.1 .1 Programação extrema . . . . . . . . . . . . . 74

7.2 Problemas encontrados . . . . . . . . . . . . 76

7.3 Implementação dos Autômatos . . . . . . . . . . . . . . . . . . 77

7.4 Arquitetura da solução - Darwin . . . . . . . . . . . . . . . . . 81

7.4.1 Implementação do indivíduo e decodificação genética . . 83

$\begin{array}{ll}\text { IV Ensaios e Conclusões } & 86\end{array}$

$\begin{array}{llr}8 & \text { Ensaios } & 88\end{array}$

8.1 Calibração do algoritmo . . . . . . . . . . . . . . . 88

8.2 Tratamento dos dados . . . . . . . . . . . . . . . . . . 88

8.3 Casos de teste . . . . . . . . . . . . . . . . . . . . . . 89

8.3.1 Linguagens utilizadas . . . . . . . . . . . . . . . . 89

8.4 Calibração do algoritmo para autômatos finitos . . . . . . . . . 89

8.4.1 Taxa de sobrevivência . . . . . . . . . . . . . . . 90

8.4.2 Taxa de normalização . . . . . . . . . . . . . . . . . . 92

8.4.3 Tamanho população . . . . . . . . . . . . . . . . 92

8.4.4 Genoma diplóide . . . . . . . . . . . . . . . . . 92

8.4.5 Coevolução . . . . . . . . . . . . . . . . . . . . 94

8.4.6 Contra-exemplo . . . . . . . . . . . . . . . . . . 95

8.4.7 Conclusões parciais . . . . . . . . . . . . . . . 96

8.5 Autômato Adaptativo . . . . . . . . . . . . . . . . . . . . 97

8.6 Coevolução . . . . . . . . . . . . . . . . . . . . 100

8.6.1 Conclusões parciais . . . . . . . . . . . . . . 101 
9 Considerações finais

9.1 Comentários críticos . . . . . . . . . . . . . . . . 102

9.2 Trabalhos futuros . . . . . . . . . . . . . . . 103

9.3 Conclusão . . . . . . . . . . . . . . . . . . . . . 105

$\begin{array}{ll}\text { Referências Bibliográficas } & 107\end{array}$ 


\section{Lista de Figuras}

4.1 Exemplo de máximo global no espaço de soluções. . . . . . . . . . 25

6.1 Funcionamento do algoritmo proposto. . . . . . . . . . . . . . 48

6.2 Formato do cromossomo para o autômato finito. . . . . . . . . . 50

6.3 Exemplo de cromossomo de um autômato finito. . . . . . . . . . . 50

6.4 Formato da região do cromossomo que codifica a camada subjacente do autômato adaptativo. . . . . . . . . . . . . . . 52

6.5 Formato da região do cromossomo que codifica a camada adaptativa do autômato adaptativo. . . . . . . . . . . . . . . 54

6.6 Formato final do cromossomo do autômato adaptativo. . . . . . . 55

6.7 Funcionamento do algoritmo proposto com coevolução. . . . . . . 58

6.8 Funcionamento do algoritmo proposto com a utilização de contra-

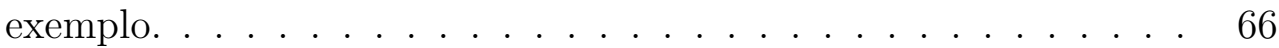

6.9 Crossover nos indivíduos diplóides. . . . . . . . . . . . . . . . 69

6.10 Fluxo dos operadores genéticos a que a população é submetida. 70

6.11 Nova camada adaptativa. . . . . . . . . . . . . . . . . 73

7.1 Arquitetura básica da implementação do autômato finito. . . . . . 78

7.2 Arquitetura básica da implementação do autômato adaptativo. . . 79

7.3 Arquitetura final da implementação do algoritmo. . . . . . . . . . 81

7.4 Arquitetura do indivíduo do tipo autômato. . . . . . . . . . . . . 84

7.5 Arquitetura do indivíduo do tipo cadeia. . . . . . . . . . . . . 85

8.1 Calibração da taxa de sobrevivência. . . . . . . . . . . . . . . . . 91

8.2 Evolução do algoritmo com diferentes taxas de sobrevivência. . . . 91

8.3 Calibração da taxa de normalização. . . . . . . . . . . . . . . . . 93

8.4 Calibração do tamanho da população. . . . . . . . . . . . . . . 93 
8.5 Autômato calculado pelo algoritmo genético com genoma diplóide. 95

8.6 Autômato calculado pelo algoritmo genético utilizando contra-exemplos. 98

8.7 Autômato fixo, com a função adaptativa calculada pelo algoritmo. 100 


\section{Lista de Tabelas}

3.1 Relação entre os tipos de linguagens com seus geradores e reconhecedores - adaptado de $($ NETO, 1987) . . . . . . . . . . . 22

6.1 Relação de valores na codificação dos tipos de ações adaptativas elementares ......................... 53

6.2 Relação de valores na codificação dos tipos de variáveis das funções adaptativas ............................. 53

6.3 Regras para a geração de cadeias de uma linguagem . . . . . . . . 56

6.4 Regras para a geração de cadeias de uma linguagem a partir do genoma de um indivíduo . . . . . . . . . . . . . . . . 59

8.1 Configuração para a calibração da taxa de sobrevivência . . . . 90

8.2 Configuração para a calibração da taxa de normalização . . . . . 92

8.3 Configuração para a calibração do tamanho da população . . . . . 94

8.4 Configuração do algoritmo com genoma diplóide . . . . . . . . . . 94

8.5 Comparação dos resultados obtidos com os genomas haplóide e

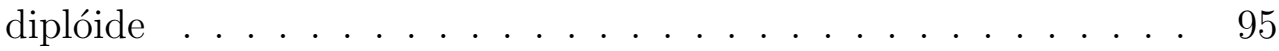

8.6 Configuração do algoritmo utilizando coevolução . . . . . . . . . . 96

8.7 Comparação dos resultados obtidos utilizando coevolução . . . . 96

8.8 Configuração do algoritmo com a utilização de contra-exemplo . 97

8.9 Comparação dos resultados obtidos com e sem a utilização de contra-exemplos . . . . . . . . . . . . . . . 97

8.10 Configuração do algoritmo na inferência de autômatos adaptativos 99

8.11 Comparação dos resultados obtidos na inferência dos autômatos adaptativos . . . . . . . . . . . . . . . . . . . 99 


\section{Parte I}

\section{Introdução}




\section{Introdução}

A capacidade de adaptação de um sistema ou dispositivo é algo muito valorizado nos dias de hoje, em que as regras de negócio estão cada vez mais sujeitas a mudanças inesperadas. Um dispositivo que apresenta a capacidade de se adequar rapidamente às mudanças do ambiente a sua volta é um dispositivo com maior valor em relação aos outros, isso porque, entre outras coisas, ele pode ser utilizado em um maior número de casos e necessita de uma quantidade menor de manutenções e alterações.

O presente trabalho é um estudo sobre as tecnologias denominadas tecnologia adaptativa e algoritmos genéticos. Essas tecnologias possuem caráter fortemente adaptativo, já que buscam a maior eficiência na execução de seus componentes, em função dos estímulos recebidos do ambiente em sua volta.

\subsection{Apresentação}

Segundo o dicionário Houaiss, o verbo adaptar significa: 1) ajustar ou acomodar (uma coisa a outra); 2) fazer com que se acomode ou se ajuste à visão; 3) modificar (obra escrita) para torná-la mais de acordo com o público a que se destina ou para transformá-la em argumento ou roteiro de cinema, televisão, teatro, rádio etc.; 4) dar nova orquestração a (músicas já conhecidas), geralmente para utilizá-las em apresentações ou espetáculos diversos; 5) tornar (-se) adequado a; acomodar (-se); harmonizar (-se); 6) tornar-se apto a; 7) demonstrar capacidade de ajustamento; acomodar-se, amoldar-se; 7.1) ajustar-se a um ambiente, a um meio; ambientarse.

Assim, pode-se entender o termo "dispositivo adaptativo", baseando-se no significado estrito da palavra, como um dispositivo que sofre modificações a fim de tornar-se apto a uma determinada atividade. Com essa definição não fica claro como a modificação no dispositivo será realizada, quando ou mesmo a causa da modificação. 
O objetivo desse trabalho é estudar as semelhanças entre as duas áreas da engenharia da computação conhecidas como tecnologia adaptativa e algoritmos genéticos. Em ambos os casos, o conceito de adaptação está fortemente presente. Porém a adaptação dos sistemas utilizando cada uma dessas tecnologias ocorre de maneiras bastante distintas.

Na área de tecnologia adaptativa a adaptação ocorre por intermédio de regras formais. Estas regras definem, de maneira específica, as condições e formas que as alterações ocorrerão no decorrer da execução do chamado dispositivo adaptativo. $\mathrm{Na}$ área de algoritmos genéticos, a adaptação ocorre de maneira estocástica, na qual um conjunto de possíveis soluções é avaliado, selecionado e recombinado a fim de gerar novas soluções mais aptas para um determinado problema.

Em ambos os casos, a adaptação é realizada pelo próprio sistema, ou seja, não depende da ação de agentes externos para a realização da adaptação. A adaptação ocorre apenas como uma resposta aos estímulos de entrada.

Colocadas as características básicas de cada área, é possível notar também diferenças muito críticas entre elas. Algoritmos genéticos não possuem regras definidas para as alterações realizadas em suas soluções, não sendo possível prever a trajetória de adaptações percorrida pelo algoritmo, dado um conjunto de estímulos de entrada.

Por outro lado, na tecnologia adaptativa, as características criativas apresentadas pelos algoritmos genéticos não são tão fortes, uma vez que, a ocorrência de uma mudança não prevista no ambiente pode fazer com que o dispositivo não se adapte de forma satisfatória. Isso ocorre porque as regras de adaptação são definidas durante a confecção do dispositivo, ficando a cargo do projetista da solução antever os possíveis cenários que o dispositivo irá encontrar.

As duas tecnologias possuem enorme potencial, como é possível comprovar através dos diversos campos em que elas são utilizadas. Portanto, é de interesse a busca por uma forma de combinar as qualidades de cada área, de forma a reduzir os efeitos de suas limitações.

Como trabalho precursor nessa área, é importante citar um artigo publicado por Hemerson Pistori (PISTORI; MARTINS; CASTRO, 2005), no qual são apresentadas algumas integrações feitas entre essas duas tecnologias. O trabalho propõe a utilização de evolução Lamarquiana, na qual as adaptações que ocorrem no indivíduo causam alterações em seu genoma. Apesar de ser uma proposta muito interessante, não faz parte do escopo desse estudo. 
Um segundo trabalho relacionado ao tema foi desenvolvido em um artigo para o Segundo Workshop de Tecnologia Adaptativa (LOPES; ROCHA, 2008). O trabalho é um estudo inicial sobre a inferência de autômatos e como tecnologias adaptativas podem contribuir para a tarefa.

Nesse artigo um autômato adaptativo implementando uma árvore de prefixo é utilizado na avaliação de autômatos inferidos por um algoritmo genético, através da comparação de seus atributos, como eficiência e tamanho. Algumas técnicas utilizadas na inferência dos autômatos foram aproveitadas, porém a utilização de árvore de prefixo não faz parte do escopo desta dissertação.

\subsection{Objetivos}

Exposta a motivação acima, o objetivo desse trabalho é estudar, além das semelhanças entre essas duas tecnologias, uma forma de uni-las, fazendo com que as diferenças encontradas sejam combinadas, contribuindo com soluções mais robustas e eficientes na resolução de problemas comuns em ambas as áreas.

Para alcançar esse objetivo, foi definida uma série de objetivos menores através dos quais espera-se chegar a contribuições relevantes. Os objetivos são formalizar e verificar o funcionamento das seguintes propostas e aplicativos:

\subsubsection{Algoritmos genéticos na inferência de autômatos fi- nitos}

Essa proposta consiste no passo inicial das pesquisas, pois com ela é possível estudar a inferência (ANGLUIN; SMITH, 1983) de objetos mais simples, cujo comportamento seja largamente conhecido. No caso, foi utilizado um autômato finito determinístico.

Outro fator importante: esse tipo de autômato possui semelhanças com o autômato adaptativo, o que contribui com reutilizações nas pesquisas referentes à inferência de autômatos adaptativos, citada mais adiante.

A inferência de autômatos, tanto adaptativos quanto finitos, é NP (Polinomial Não-Determinístico) (CORMEN; LEISERSON; RIVEST, 1990) (PAPADIMITRIOU; STEIGLITZ, 1998), isso porque a inferência, da maneira que é proposta, procura determinar um autômato a partir de exemplos da cadeias que compõem a linguagem.

Dessa forma, não é possível, a partir de um algoritmo determinístico e com 
tempo polinomial, encontrar um autômato que represente a linguagem, prevendo cadeias não utilizadas na fase de treinamento da população.

De fato, não é possível prever todas as cadeias pertencentes a uma determinada linguagem, uma vez que a linguagem é apenas um conjunto de cadeias, podendo não possuir um padrão a ser inferido pelo algoritmo.

A idéia por trás desse objetivo é chegar a um autômato que identifique exatamente o padrão de formação das cadeias utilizadas no treinamento da população, desde que haja um padrão.

\subsubsection{Relação de dominância dinâmica em genomas di- plóides}

Na busca por melhores resultados, foi observada a possibilidade de utilizar genomas diploides na codificação genética dos autômatos. Para que tal implementação seja viável é necessária a elaboração de uma relação de dominância entre os alelos para decodificar o genótipo dos indivíduos no fenótipo apresentado pelos autômatos.

Posto isso, é proposta a relação de dominância dinâmica, que é uma relação de dominância que varia de acordo com o genótipo de toda a população.

\subsubsection{Algoritmos genéticos para a inferência de autômatos adaptativos}

Essa proposta é o objetivo principal do presente trabalho. Trata-se de uma evolução da proposta da utilização de um algoritmo genético para a inferência de autômatos finitos determinísticos.

Esse objetivo tem duas grandes motivações:

1. Esse algoritmo pode vir a se tornar uma poderosa ferramenta de auxílio no projeto de autômatos adaptativos, que em muitos casos não se trata de uma tarefa trivial.

2. A análise do processo de inferência de autômatos adaptativos é uma atividade exploratória, que pode trazer conclusões interessantes sobre a essência do funcionamento desses dispositivos e sua estrutura interna. 


\subsubsection{Nova camada adaptativa para autômatos adaptati- VOS}

Com a análise dos resultados obtidos dos objetivos anteriores, espera-se tirar conclusões sobre potenciais aplicações da combinação dessas duas tecnologias. Mesmo não sendo possível realizar um estudo completo sobre o assunto, procurouse indicar possíveis caminhos para trabalhos futuros.

Dentre os trabalhos futuros de interesse, espera-se obter mais conhecimento sobre a possibilidade de inclusão de características inerentes aos algoritmos genéticos nas camadas adaptativas dos autômatos adaptativos, de forma que sejam introduzidas características criativas aos mesmos.

Ao invés de depender do projetista para suprir o dispositivo com todas as ações adaptativas, estas são criadas em tempo de execução, através da antecipação da leitura dos elementos pertencentes à cadeia de entrada, por parte da camada adaptativa, que possui internamente, em sua implementação, um algoritmo genético.

\subsubsection{A arquitetura Darwin}

Darwin é uma arquitetura de software que oferece um arcabouço com o objetivo de facilitar o estudo das várias implementações e configuração envolvendo ambas as áreas em questão. Esse arcabouço é definido através de um conjunto de classes que devem ser implementadas ou estendidas para obter as configurações de interesse.

Esse aplicativo é o ponto de partida para qualquer experimentação ou implementação referente às propostas acima. Estima-se que ele possa vir a evoluir, tornando-se uma ferramenta bastante útil para outros pesquisadores dessas áreas.

\subsection{Estrutura}

Essa dissertação é dividida em quatro partes: a segunda parte entitulada "Fundamentos" possui um resumo da teoria utilizada nas pesquisas do presente trabalho, revisando conceitos básicos sobre a teoria da computação, passando por autômatos adaptativos e terminando em algoritmos genéticos.

A parte III apresenta as principais proposta do trabalho e termina comentando a implementação de algumas dessas propostas, como as dificuldades encontradas e as decisões tomadas no processo de desenvolvimento do aplicativo. 
A parte IV explica os testes realizados e discute os resultados finais obtidos. Nela também é feita uma análise ampla sobre o status da pesquisa. E por fim, são propostas possíveis combinações do uso de ambas as tecnologias em trabalhos futuros.

Ainda na parte IV, as conclusões finais do trabalho são expostas, baseadas nos resultados obtidos dos experimentos e nas observações realizadas durante o desenvolvimento da pesquisa, procurando reforçar as propostas feitas para pesquisas futuras. 
Parte II

\section{Fundamentos teóricos}


Neste seção serão definidos alguns conceitos básicos da teoria da computação utilizados durante as pesquisas, passando por métodos de busca e algoritmos genéticos. 


\section{Alfabetos, cadeias e linguagens}

Para definir esses conceitos foi utilizado o exposto por Lewis e Papadimitriou (LEWIS; PAPADIMITRIOU, 1981), sendo assim, alfabeto é um conjunto finito de símbolos, qualquer símbolo pode estar presente na definição de um alfabeto. Contudo, o mais usual é a utilização de letras, números e símbolos como \#, \$, *, etc.

Uma seqüência finita de símbolos pertencentes a um alfabeto constitui uma cadeia. Ela é representada, simplesmente, pela seqüência de símbolos justapostos, por exemplo: abcd. Existem também cadeias vazias, o símbolo $e$ é utilizado para representá-las. O conjunto de todas as cadeias, incluindo a cadeia vazia, sobre um alfabeto $\Sigma$ é denotado por $\Sigma^{*}$. O símbolo na enésima posição da cadeia $\mathrm{w}$ pode ser representado como $\mathrm{w}(\mathrm{n})$, de forma que, para a cadeia $\mathrm{w}=$ abcd, temos $\mathrm{w}(2)=\mathrm{b}$.

As cadeias possuem como característica seu comprimento que pode ser representado pelos símbolos "|.|", assim o comprimento da cadeia abcd é $\mid$ abcd $\mid=4$ e no caso da cadeia vazia, $|e|=0$. A operação de concatenação é definida para cadeias, sendo que duas cadeias podem ser combinadas na formação de uma terceira.

A concatenação das cadeias x e y pode ser representadas apenas por xy, e a operação é definida como:

$\mathrm{w}=\mathrm{xy}$ se e somente se $|w|=|x|+|y|, \mathrm{w}(\mathrm{j})=\mathrm{x}(\mathrm{j})$ para $\mathrm{j}=1, \ldots,|x|$, e $w(|x|+j)=$ $y(j)$ para $\mathrm{j}=1, \ldots,|y|$.

Qualquer conjunto de cadeias sobre um alfabeto $\Sigma$, ou seja, qualquer subconjunto de $\Sigma^{*}$ é considerado uma linguagem. As operações aplicadas a conjuntos, como união, intersecção e diferença se aplicam também às linguagens, pois estas são conjuntos de cadeias.

Além dessas operações, estão definidas as operações de concatenação de linguagens e a de fechamento. A operação de concatenação é definida como L = 
L1L2, sendo que:

$\mathrm{L}=\left\{\mathrm{w}: \mathrm{w}=\mathrm{xy}, \mathrm{x} \in L_{1}\right.$ e $\left.\mathrm{y} \in L_{2}\right\}$

A operação de fechamento de Kleene para uma linguagem L é representada por $\mathrm{L}^{*}$ e definida como:

$$
\mathrm{L}^{*}=\left\{\mathrm{w} \in \Sigma^{*}: \mathrm{w}=w_{1} w_{2} \ldots w_{k}\right\}, \text { para } \mathrm{k} \geq 0 \text { e } w_{1}, w_{2}, \ldots, w_{k} \in \mathrm{L} .
$$

\subsection{Representação de linguagens}

A representação de uma linguagem pode ser feita de diversas formas, o caso mais trivial é o de linguagens finitas, definidas por um conjunto finito de cadeias. Sua representação pode ser feita através da enumeração simples de todas as cadeias que as compõem.

Quanto às linguagens infinitas, não é possível, a representação por enumeração de todas elas. Isso ocorre porque dado um conjunto finito de símbolos representando um determinado alfabeto, todas as possíveis cadeias geradas por esse alfabeto, $\Sigma^{*}$, é um conjunto infinitamente contável. Porém, todos os subconjuntos que podem ser feitos a partir de $\Sigma^{*}$, ou seja, o conjunto potência de $\Sigma^{*}$, não é contável, uma vez que, qualquer conjunto potência de qualquer conjunto infinitamente contável não é contável.

Assim, com uma quantidade contável de representações e uma quantidade incontável de linguagens a serem representadas, fica claro que não é possível representar todas as linguagens (LEWIS; PAPADIMITRIOU, 1981).

No entanto, apesar do constatado acima, há maneiras de representar algumas linguagens de interesse, por exemplo através de expressões regulares e gramáticas. Esses dois elementos podem ser entendidos como geradores de linguagens, de maneira que a linguagem definida por esses dispositivos é o conjunto de todas as cadeias que eles podem produzir.

\subsection{Expressões regulares}

A expressão regular sobre um alfabeto $\Sigma$ é o conjunto das cadeias sobre o alfabeto, sendo que:

1. $\emptyset$ e cada membro de $\Sigma$ é uma expressão regular;

2. se $\alpha$ e $\beta$ são expressões regulares então $(\alpha \beta)$ também é; 
3. se $\alpha$ e $\beta$ são expressões regulares então $(\alpha \cup \beta)$ também é;

4. se $\alpha$ é uma expressão regular então $\alpha^{*}$ também é, e

5. nada mais pode ser considerado uma expressão regular, a menos que, seja proveniente das regras de 1 a 4 .

Cada expressão regular representa uma linguagem, sendo que $\cup$ representa a união dos conjuntos, ${ }^{*}$ representa a estrela de Kleene e $\emptyset$ o conjunto vazio.

Seja L uma função que, dada uma expressão regular, define a linguagem representada por esta última, então a função é definida como:

1. $\mathrm{L}(\emptyset)=\emptyset \mathrm{e} \mathrm{L}(\mathrm{a})=\{a\}$, para $\mathrm{a} \in \Sigma$;

2. se $\alpha$ e $\beta$ são expressões regulares, então $\mathrm{L}((\alpha \beta))=\mathrm{L}(\alpha) \mathrm{L}(\beta)$

3. se $\alpha$ e $\beta$ são expressões regulares, então $\mathrm{L}((\alpha \cup \beta))=\mathrm{L}(\alpha) \cup \mathrm{L}(\beta)$

4. se $\alpha$ é uma expressão regular, então $\mathrm{L}\left(\alpha^{*}\right)=\mathrm{L}(\alpha)^{*}$

As declarações acima definem que cada expressão regular é associada a uma linguagem e as combinações de expressões regulares também são associadas a combinações de linguagens.

\subsection{Gramáticas}

Como dito anteriormente, assim como as expressões regulares, gramáticas são geradores de linguagens e podem ser definidas por uma quádrupla $G=(V, \Sigma, R, S)$, segundo (LEWIS; PAPADIMITRIOU, 1981), sendo que:

1. V é um alfabeto;

2. $\Sigma \subseteq \mathrm{V}$ é o conjunto de símbolos terminais e $V-\Sigma$ é chamado de conjunto dos símbolos não-terminais;

3. $S \in V-\Sigma$ é o símbolo não-terminal inicial;

4. R é um conjunto de regras de formação e um subconjunto finito de $\left(V^{*}(V-\right.$ $\left.\Sigma) V^{*}\right) \times V^{*}$. 
Cada regra de formação de $\mathrm{R}$, também conhecida como produção, tem o formato $\alpha \rightarrow \beta$, onde $\alpha$ é uma cadeia contendo pelo menos um não-terminal, ou seja, $\alpha \in V^{*}(V-\Sigma) V^{*}$ e $\beta$ é uma cadeia eventualmente vazia, contendo terminais e não-terminais.

A linguagem definida ou gerada por $G$ é representada por $L(G)$. A geração das cadeias pertencentes a $\mathrm{L}(\mathrm{G})$ ocorre sempre a partir do símbolo inicial S. Esta geração é realizada através de um sistema de substituições, no qual as produções indicam quais as substituições possíveis para os não-terminais, para formar uma cadeia constituída apenas de elementos terminais, de forma que a cadeia resultante é uma cadeia pertencente a $\mathrm{L}(\mathrm{G})$.

Há uma hierarquia de classes na qual as gramáticas estão contidas, cada gramática é classificada dentro dessa hierarquia conforme as restrições impostas ao formato das produções que as definem, conforme (LEWIS; PAPADIMITRIOU, 1981), são elas:

As gramáticas possuem uma hierarquia de classes que varia conforme as restrições impostas ao formato das produções que as definem, conforme (LEWIS; PAPADIMITRIOU, 1981), são elas:

Gramáticas irrestritas : esse tipo de gramática não possui qualquer limitação imposta.

Gramáticas sensíveis ao contexto : nenhuma substituição pode reduzir o comprimento da forma sentencial, ou seja, $\alpha \rightarrow \beta$ pertence a essa classe de gramáticas se e somente se $|\alpha| \leq|\beta|$.

Gramáticas livres de contexto : as produções são restritas à forma $A \rightarrow \alpha$, ou seja, o lado esquerdo da produção é um não-terminal isolado. Dessa forma, a substituição de A é independente do contexto no qual este símbolo está imerso.

Gramáticas lineares à direita (ou esquerda) : as produções são restritas às seguintes formas, $A \rightarrow \alpha B$ (ou $A \rightarrow B \alpha$ ) e $A \rightarrow \alpha$, com $\alpha \in \Sigma^{*}$. Gramáticas dessa classe admitem apenas regras de substituição de um nãoterminal por uma cadeia de terminais seguida (ou precedida) por um único não-terminal ou por uma cadeia formada apenas de terminais. Dessa maneira, evita-se a ocorrência de aninhamentos sintáticos.

Maiores informações sobre gramáticas podem ser obtidas nas obras de Lewis e Papadimitriou(LEWIS; PAPADIMITRIOU, 1981). 


\subsection{Autômatos de estados finitos determinísti- $\cos$}

Ainda na área de linguagens, além dos geradores há também os reconhecedores, que são dispositivos computacionais capazes de determinar se uma cadeia pertence ou não a uma linguagem.

Ainda considerando o exposto por Lewis e Papadimitriou (LEWIS; PAPADIMITRIOU, 1981), um autômato finito determinístico pode ser entendido como um dispositivo de reconhecimento de cadeias pertencentes a linguagens regulares.

Os autômatos finitos são modelos computacionais bastante restritos, comparados a outros dispositivos, como a máquina de Turing, ou uma unidade lógica aritmética de um computador. Eles podem ser definidos através de uma quíntupla $M=(K, \Sigma, \delta, s, F)$, sendo que:

1. K é um conjunto finito de estados;

2. $\Sigma$ é um alfabeto;

3. $s \in K$ é o estado inicial;

4. $F \subseteq K$ é o conjunto de estados finais ou de aceitação;

5. e $\delta$ é a função de transição e uma função de $\mathrm{K} \times \Sigma$ para $\mathrm{K}$.

Esta função $\delta$ é a responsável pela definição das regras de transição do autômato ao receber um determinado elemento da cadeia de entrada. A execução do autômato se dá através do consumo desses símbolos provenientes da cadeia.

A configuração de um autômato é definida por seu estado atual e a cadeia restante a ser consumida. O símbolo ' $\vdash$ ' representa uma relação binária entre duas configurações de um autômato. Ela se aplica se e somente se a máquina puder passar de uma configuração para outra, como resultado de apenas um passo de sua execução.

Dessa forma, para o autômato $M$, pode-se dizer que $(\mathrm{q}, \mathrm{w}) \vdash\left(\mathrm{q}^{\prime}\right.$, w') se e somente se, para as cadeias w e w', temos $w=\rho w^{\prime} \operatorname{com} \rho \in \Sigma$ e o próximo estado da máquina M recebendo $\rho$ no estado q é q'.

Assim $\vdash$ é uma relação de $K \times \Sigma^{+}$para $K \times \Sigma^{*}$, ou seja, para cada configuração, com exceção de $(\mathrm{q}, e)$, há uma única próxima configuração determinada. A configuração ( $q, e$ ) indica que o autômato consumiu toda a cadeia de entrada, terminando sua execução nesse ponto. 
O fechamento reflexivo e transitivo de $\vdash$ é denotado por $\vdash^{*}$, indicando a ocorrência de sucessivos passos na execução do autômato, ou mesmo nenhum. Uma cadeia $w \in \Sigma^{*}$ é considerada aceita por M se e somente se existir um estado $q \in F$ de forma que $(s, w) \vdash^{*}(q, e)$. A linguagem aceita por $\mathrm{M}$ é denotada por $\mathrm{L}(\mathrm{M})$. 


\section{Tecnologia adaptativa}

A tecnologia adaptativa é um campo de pesquisa voltado para o estudo e formalização dos chamados dispositivos adaptativos. Como descrito por João José Neto (NETO, 1993) (NETO, 2001), um dispositivo adaptativo é um dispositivo capaz de realizar modificações em sua própria estrutura e comportamento, em resposta direta a algum estímulo de entrada, sem a interferência de agentes externos.

Esses dispositivos são constituídos de duas partes, um dispositivo subjacente e uma camada adaptativa. O dispositivo subjacente é o responsável pela definição da estrutura e do comportamento instantâneo do dispositivo, enquanto a camada adaptativa é a responsável pelas mudanças que ocorrem nesse dispositivo, durante sua execução.

\subsection{Dispositivo subjacente}

O dispositivo ou camada subjacente é um dispositivo normalmente não adaptativo e definido por um conjunto fixo de regras, como autômatos finitos determinísticos, redes de Markov ou tabelas de decisão.

A cada estágio de sua operação, esse dispositivo assume alguma configuração, que normalmente é constituída das informações de entrada a serem processadas e seu estado interno. Independentemente de como foi alcançada, uma configuração determina o comportamento futuro do dispositivo.

O dispositivo inicia seu processamento a partir de uma configuração inicial e sua execução se dá através de sucessivas transições de uma configuração para a próxima, em resposta aos elementos consumidos do fluxo de entrada.

O fluxo de entrada varia de acordo com o tipo de dispositivo, no caso de um autômato o fluxo é uma cadeia de símbolos e apenas os elementos a serem computados importam na definição da configuração do dispositivo. No caso de uma máquina de Turing, o fluxo de entrada é representado pela fita de dados a ser processada, nesse caso os dados já processados importam para a definição 
da configuração atual do dispositivo, pois a máquina pode voltar a utilizar esses dados no futuro.

Ao final da execução, o dispositivo alcança uma configuração que pode indicar se o fluxo de entrada foi aceito ou rejeitado, de maneira que é possível dividir o conjunto das possíveis configurações do dispositivo em dois, o conjunto das configurações de aceitação e o de rejeição.

As passagens de uma configuração para outra, em um dispositivo desse tipo, são determinadas pelo conjunto de regras que o define, de forma que cada regra mapeia cada configuração do dispositivo para uma nova configuração. O dispositivo é dito determinístico se o conjunto de regras que o define permite apenas uma transição válida, a toda e qualquer configuração válida do dispositivo.

Se houver mais de uma transição definida para uma mesma configuração, então o dispositivo é dito não-determinístico.

Um dispositivo guiado por regras pode ser definido pela sêxtupla (C, NR, S, $\left.c_{0}, \mathrm{~A}, \mathrm{NA}\right)$, sendo que:

- C é o conjunto de todas as possíveis configurações que o dispositivo pode assumir;

- NR é o conjunto de regras que define o dispositivo;

- S é o conjunto de todos os elementos de entrada, incluindo $\epsilon$, a cadeia vazia;

- $c_{0}$ é a configuração inicial do dispositivo;

- $\mathrm{A} \subseteq \mathrm{C}$ é o subconjunto de configurações de aceitação e

- NA é o conjunto de todos os elementos de saída do dispositivo, como efeito colateral da execução de alguma de suas regras. Esses elementos podem ser mapeados em chamadas de função e são opcionais.

\subsection{Camada Adaptativa}

A camada adaptativa é a parte do dispositivo adaptativo responsável pela mudança em sua estrutura, em resposta ao processamento dos símbolos de entrada.

Essa modificação na estrutura desses dispositivos se dá através da alteração no conjunto das regras que os definem. Estas modificações ocorrem por meio da execução das chamadas ações adaptativas, que são descritas através de funções adaptativas. 


\subsubsection{Funções adaptativas}

As funções adaptativas são funções paramétricas, constituídas de uma lista de ações adaptativas elementares. Esta lista define quais as ações adaptativas que a camada adaptativa irá realizar no dispositivo subjacente, quando acionada em resposta a algum elemento da entrada.

Existem três tipos de ações adaptativas elementares, são elas :

- Ação de consulta : Ação responsável pela busca por padrões nas regras de formação do dispositivo subjacente e é representada por ?[padrão], as variáveis da função adaptativa são preenchidas na execução desse tipo de ação;

- Ação de inserção : Ação que determina qual regra deve ser inserida no conjunto de regras que define o dispositivo subjacente e é representada por $+[$ padrão];

- Ação de remoção : Ação que determina qual regra deve ser removida do conjunto de regras do dispositivo subjacente e é representada por -[padrão]. Essa ação possui a mesma característica da ação elementar de consulta, a característica de buscar por padrões e preencher variáveis, para que sua execução possa ocorrer.

O padrão das ações adaptativas elementares, normalmente, possui a mesma forma das regras do dispositivo subjacente. A diferença é que os padrões podem conter variáveis no lugar de alguns elementos da regra de formação. Essas variáveis são utilizadas no contexto de execução da função em questão.

Durante a execução das ações adaptativas elementares de consulta ou remoção, pode haver ocorrências em que não é possível definir algumas das variáveis que constituem a ação. Nesses casos, a ação adaptativa elementar não é executada.

Com base em (PISTORI, 2003), formalmente é possível definir uma função adaptativa como uma nônupla (F, P, V, G, C, R, I, A, B), sendo que:

- F é o nome da função adaptativa;

- P é a lista de parâmetros formais a serem passados na execução da função;

- V é a lista de identificadores das variáveis;

- G é a lista de identificadores dos geradores; 
- C é a lista de ações de consulta;

- R é a lista de ações de remoção;

- I é a lista de ações de inserção;

- A é uma ação adaptativa inicial, sendo esta opcional, e

- B é uma ação adaptativa final, sendo esta também opcional.

$\mathrm{P}$ é uma lista de parâmetros formais recebidos na invocação da função. V é uma lista de variáveis, cujos valores serão definidos durante a execução da função, através das ações elementares de consulta e remoção. G é uma lista de geradores, que são variáveis especiais, preenchidas automaticamente com valores únicos, ainda não utilizados na definição corrente do dispositivo. Uma vez definido o valor de uma variável, ele não pode mais ser alterado.

A ação adaptativa inicial A é uma função adaptativa que deve ser executada antes de qualquer ação adaptativa elementar presente na função. A função adaptativa final B é uma função adaptativa que deve ser executada depois de todas as ações adaptativas elementares da função. Ambas as funções só serão executadas se todos os argumentos passados no momento de suas execuções estiverem definidos.

A execução da função adaptativa se dá através de sua invocação, que é representada por (F', $\left.\mathrm{P}^{\prime}\right)$, sendo que $\mathrm{F}^{\prime}$ é o nome da função adaptativa e $\mathrm{P}^{\prime}$ é a lista de argumentos passada para a função.

A execução da função ocorre através dos seguintes passos:

1. Durante a invocação da função, os argumentos contidos pela lista $\mathrm{P}^{\prime}$ são passados por valor para a lista $\mathrm{P}$, definida anteriormente;

2. Todos os geradores pertencentes à lista G são definidos, atribuindo-se valores novos e únicos a cada um deles;

3. Todas as variáveis pertencentes à lista V são marcadas como indefinidas;

4. A ação adaptativa inicial A é executada desde que nenhum de seus argumentos esteja indefinido, podendo ser passado como argumento os parâmetros recebidos da lista $\mathrm{P}$ e os geradores da lista $\mathrm{G}$;

5. Executam-se as ações elementares de consulta, incluindo as consultas realizadas pelas ações de remoção, de forma que o maior número possível de variáveis seja definido; 
6. Executam-se, em qualquer ordem, todas as ações de remoção;

7. Executam-se, em qualquer ordem, todas as ações de inserção;

8. A ação adaptativa final B é executada, se existir e desde que todos os seus parâmetros estejam definidos, e

9. Finalmente, a função é finalizada, retornando a execução do dispositivo adaptativo ao seu contexto original.

\subsection{Autômatos adaptativos}

Como exemplo de um dispositivo adaptativo temos o autômato adaptativo. Ele tem como dispositivo subjacente um autômato, podendo ser um autômato de pilha ou simplesmente um autômato finito determinístico.

Usualmente, por razões históricas, o termo "autômato adaptativo" refere-se ao autômato de pilha estruturado adaptativo. No presente trabalho, o autômato adaptativo a ser estudado é o autômato finito adaptativo, que possui como dispositivo subjacente um autômato finito. Portanto, nas seguintes referências ao "autômato adaptativo", deve-se entender "autômato finito adaptativo".

Esse autômato adaptativo, no início de sua operação, apresenta um autômato inicial, que será modificado no decorrer de sua execução, como resultado da aplicação de suas ações adaptativas.

Essas modificações no autômato, no decorrer de sua execução, podem ser entendidas como o surgimento de novos autômatos, como se o autômato adaptativo percorresse um espaço de máquinas de estados ao computar uma determinada cadeia. Esse caminho é conhecido como trajetória de reconhecimento.

Assim, pode-se entender como máquinas diferentes o autômato inicial, o final e todos os autômatos intermediários. De maneira formal, é possível definir os seguintes elementos durante a trajetória de reconhecimento de um autômato adaptativo:

- w é toda a cadeia de entrada a ser reconhecida;

- $E^{0}$ é a máquina de estados inicial do autômato adaptativo;

- $E^{n}$ é a máquina de estados que o autômato adaptativo apresenta ao final de sua execução; 
- $E^{i}$ é a máquina de estados apresentada pelo autômato adaptativo após a i-ésima execução de suas transições adaptativas.

Pode-se dizer que a trajetória de reconhecimento do autômato adaptativo ao receber a cadeia w é $\left(E^{0}, \alpha^{0}\right) \rightarrow\left(E^{1}, \alpha^{1}\right) \rightarrow\left(E^{2}, \alpha^{2}\right) \rightarrow \ldots \rightarrow\left(E^{n}, \alpha^{n}\right)$. Sendo que $w=\alpha^{0} \alpha^{1} \alpha^{2} \ldots \alpha^{n}$ e $\left(E^{i}, \alpha^{i}\right)$ representa o consumo da sub-cadeia $\alpha^{i}$ pela máquina de estados $E^{i}$.

Para o caso de autômatos finitos adaptativos, a representação do autômato é feita através da mesma quíntupla que define um autômato não-adaptativo, porém em seu conjunto de transições, a representação de suas regras será diferente. Isso ocorre para que as ações adaptativas que devem ser executadas antes ou depois das transições sejam representadas.

Como exemplo de notação para uma transição de um autômato finito adaptativo, pode-se citar a seguinte, que é descrita como um caso particular em (NETO, 1993):

$(e, s): A, \rightarrow e^{\prime}, B$, sendo :

- e é o estado corrente do autômato;

- s é o elemento a ser consumido pelo autômato;

- A é uma ação adaptativa opcional a ser executada antes da transição;

- e' é o estado destino da transição e

- B é uma ação adaptativa opcional a ser executada depois da transição.

Conforme exposto por Ricardo Rocha (ROCHA; NETO, 2000), um autômato adaptativo é um dispositivo com poder computacional equivalente ao da máquina de Turing. Assim, ele pode ser utilizado no reconhecimento de linguagens mais complexas que as linguagens regulares, como as linguagens livres e sensíveis ao contexto.

\subsection{Hierarquia de linguagens}

Existe uma classificação entre as linguagens formais, sendo que para cada classe de linguagem é necessário um tipo de reconhecedor e também um tipo de gerador. Baseado em (NETO, 1987), pode-se propor a tabela 3.1, sem a pretensão de esgotar todas as possibilidades para cada tipo de linguagem: 
Tabela 3.1: Relação entre os tipos de linguagens com seus geradores e reconhecedores - adaptado de (NETO, 1987)

\begin{tabular}{|c|l|l|l|}
\hline \hline Tipo & Nome & Geradores & Reconhecedores \\
\hline 0 & $\begin{array}{l}\text { Recursivamente } \\
\text { enumeráveis }\end{array}$ & Gramáticas irrestritas & $\begin{array}{l}\text { Máquina de Turing e } \\
\text { Autômatos adaptati- } \\
\text { vos }\end{array}$ \\
\hline 1 & $\begin{array}{l}\text { Sensíveis ao con- } \\
\text { texto }\end{array}$ & $\begin{array}{l}\text { Gramáticas sensíveis } \\
\text { ao contexto }\end{array}$ & $\begin{array}{l}\text { Máquina de Turing } \\
\text { com memória limitada }\end{array}$ \\
\hline 2 & $\begin{array}{l}\text { Livres de con- } \\
\text { texto }\end{array}$ & $\begin{array}{l}\text { Gramáticas livres de } \\
\text { contexto }\end{array}$ & Autômato de pilhas \\
\hline Regulares & $\begin{array}{l}\text { Gramáticas lineares à } \\
\text { direita expressões re- } \\
\text { gulares }\end{array}$ & Autômatos Finitos \\
\hline \hline
\end{tabular}

Vale notar que essa relação entre as linguagens, seus tipos e os tipos de gramáticas correspondem à classificação de linguagens formais descrita por Noam Chomsky em 1959 (CHOMSKY, 1959).

Uma vez definida a classificação das linguagens, apenas as linguagens regulares podem ser reconhecidas por autômatos finitos. Os demais tipos de linguagens devem ser reconhecidas por autômatos adaptativos ou outros dispositivos com o mesmo poder computacional. 


\section{Algoritmos de busca}

A seguir serão listados alguns métodos de busca de soluções, para situar os algoritmos genéticos no contexto geral dos métodos de busca. Estes métodos também servirão como base para as justificativas das escolhas realizadas nos capítulos seguintes.

\subsection{Algoritmos de busca e otimização}

Algoritmos de busca consistem em processos que buscam de forma iterativa uma solução, para um determinado problema, em um espaço de soluções. Os problemas a serem resolvidos podem ser diversos, como o valor de uma variável, um polinômio que melhor descreve uma curva, etc (RUSSELL; NORVIG, 2003).

O processo de busca pode ser entendido também como um processo de otimização, no sentido de que uma solução melhor, em relação a uma já existente, está sendo procurada. Assim, o algoritmo iniciado com uma solução, ou com um conjunto de soluções, de forma aleatória ou não, procura no espaço por soluções mais adequadas (EBERHART; SHI; KENNEDY, 2001).

Seguem algumas definições importantes de conceitos comuns nessa área da computação, baseados em (EBERHART; SHI; KENNEDY, 2001). Esses conceitos serão utilizados nas implementações discutidas nos capítulos seguintes.

\subsubsection{Hiperespaço}

Hiperespaço é o nome dado ao espaço de soluções de um determinado problema que possui mais de três dimensões. Trata-se de um espaço de soluções com número de dimensões superior ao espaço euclidiano (KUCHA, 1976).

A utilização de espaços com mais de três dimensões é bastante comum , uma vez que cada dimensão pode representar uma característica que varia de forma independente entre as soluções. Não é possível a representação gráfica desse tipo 
de espaço.

\subsubsection{Adequação}

O conceito de adequação (ou fitness), muito comum em computação evolutiva, refere-se à adequação de uma solução para um determinado problema. Pode-se falar em termos de distância, esse pode ser entendido como o conceito inverso ao da adequação, indicando o quanto uma solução está longe do ideal. (RUSSELL; NORVIG, 2003) (EBERHART; SHI; KENNEDY, 2001)

O conceito de adequação normalmente é representado por uma grandeza escalar, calculada pela função de avaliação ou adequação. Essa função calcula a adequação a partir de uma grandeza vetorial, multidimensional, que constitui a posição da solução no espaço de busca.

\subsubsection{Convergência}

Convergência é a característica apresentada pelos algoritmos de alcançar, em uma determinada quantidade de tempo de processamento, uma solução satisfatória.

Essa característica depende fundamentalmente da função de avaliação e da maneira como o algoritmo percorre o hiperespaço em busca de novas soluções (LANGDON; POLI, 2002).

\subsection{4 Ótimos globais e locais}

Conforme observado anteriormente, a função de adequação retorna uma grandeza escalar, dada uma posição no espaço de soluções. O fitness landscape consiste na representação da adequação de cada possível solução, ele é obtido criando-se uma dimensão a mais para representar a adequação das soluções no hiperespaço (EBERHART; SHI; KENNEDY, 2001).

Por exemplo, um espaço de soluções com duas dimensões, x e y, ao adicionar uma nova dimensão z para representar a adequação de cada uma das soluções, obtém-se o fitness landscape do problema em questão. A figura 4.1 contém um exemplo gráfico para a função de adequação $\mathrm{f}(\mathrm{x})=x * e^{\left(-x^{2}-y^{2}\right)}$ nesse espaço.

Os pontos onde a adequação apresenta maior valor são chamados pontos de ótimo, sendo que o ponto onde a função de adequação possui o maior valor, considerando todo o espaço, é chamado ótimo global e pontos onde a função possui 
Figura 4.1: Exemplo de máximo global no espaço de soluções.

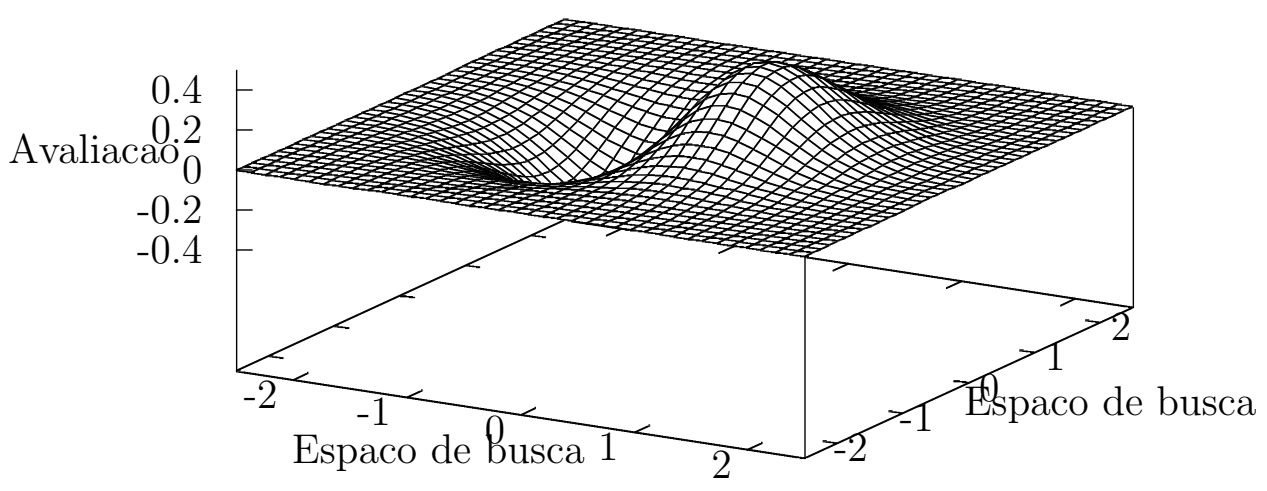

maior valor, considerando apenas os pontos próximos, sendo que há pontos com adequação maior em outras regiões do espaço, são chamados ótimos locais.

Um problema comum que ocorre durante a execução de algoritmos de busca se dá quando o algoritmo fica "preso" em um ótimo local, ou seja, ele não consegue alcançar novos pontos com avaliações superiores no espaço. Isso ocorre porque, dependendo da implementação do algoritmo, os pontos escolhidos para a próxima iteração estão próximos do último ponto avaliado. Dessa forma, se o ponto avaliado estiver em um ótimo local, todos os pontos próximos possuirão avaliações inferiores a ele, de maneira que ocorrerá uma tendência de o algoritmo permanecer nessa região e nunca convergir para uma solução mais adequada.

\subsubsection{Critério de parada}

O critério de parada é uma característica que os algoritmos de busca possuem, definindo as condições que devem ser alcançadas para que sua execução seja interrompida.

Normalmente o critério de parada é alcançado quando a solução que o algoritmo encontrou é satisfatória ou quando a adequação das soluções encontradas não mais melhora de uma iteração para outra.

A distância ou a adequação são as medidas utilizadas para verificar se a solução é satisfatória ou não. Uma solução é considerada satisfatória se sua adequação (ou distância) está contida em uma determinada faixa de valores pre- 
viamente fixados.

Nem sempre é possível determinar qual solução é satisfatória para um determinado problema. Isso ocorre quando não se tem conhecimento suficiente sobre o problema que o algoritmo está otimizando, ou seja, quando não é possível distinguir se o algoritmo se encontra em um ótimo local ou global (RUSSELL; NORVIG, 2003).

\subsection{Algoritmos de busca convencionais}

Segue a descrição de alguns dos algoritmos de busca mais comuns, que opera sem a utilização de métodos evolutivos. A descrição desses algoritmos tem como objetivo situar os algoritmos genéticos, utilizados no presente trabalho, no contexto dos algoritmos de busca e contrastar suas principais diferenças, sem a intenção de citar todas as técnicas conhecidas(FREGNI, 1997).

\subsubsection{Hill climbing}

Hill climbing, como apresentado por Moret e Shapiro (MORET; SHAPIRO, 1991), é um método que busca o ótimo a partir de um ponto aleatório do hiperespaço, sempre no sentido do gradiente da função de adequação.

Esse método tem a desvantagem de ficar facilmente preso em algum ótimo local deixando de alcançar o ótimo global do hiperespaço. O espaço de soluções é determinado de tal forma que sempre deve ser possível saber qual solução é vizinha de uma determinada solução e também deve ser possível atingir qualquer ponto do espaço a partir de qualquer outro ponto, apenas caminhando de vizinho em vizinho pelas soluções.

O método pode ser descrito pelos seguintes passos:

1. Um ponto aleatório é escolhido no espaço. Esse ponto é avaliado e ele se torna o ponto corrente.

2. Um de seus vizinhos é sorteado e avaliado.

3. Se a avaliação do vizinho for superior à avaliação do ponto corrente, o ponto vizinho passa a ser o ponto corrente.

4. O algoritmo volta para o passo 2. 
Apesar de existirem elementos aleatórios no algoritmo, não é possível garantir que ele irá alcançar a melhor solução, nem é possível evitar que ele fique preso em algum ótimo local.

O método pára quando encontrar um ponto com avaliação máxima, ou seja, um ponto que não possui vizinhos com avaliação superior à dele. Para determinar se o ponto possui vizinhos com avaliação superior é necessário verificar todos eles.

Existe uma variante desse algoritmo no qual todos os vizinhos são avaliados e o vizinho com melhor avaliação é escolhido para se tornar o próximo ponto, essa variante é conhecida como Stepest-Hill-climbing (RUSSELL; NORVIG, 2003).

\subsubsection{Simulated Annealing}

Esse método é baseado no método Hill climbing e faz analogia ao processo de têmpera do aço. O processo de têmpera provoca um desarranjo na estrutura molecular do aço, para que as subseqüentes organizações atinjam níveis melhores em relação às organizações anteriores (KIRKPATRICK; GELATT; VECCHI, 1983).

Dessa forma, foi introduzida uma variável x, que é uma analogia à temperatura no processo de têmpera. Essa variável possui um valor menor ou igual a 1 no início do processo.

O valor de $\mathrm{x}$ diminui no decorrer do processo, até alcançar o valor zero. A variável x no algoritmo indica a probabilidade de aceitar um vizinho da solução corrente, mesmo que ele tenha uma avaliação inferior à mesma. Essa estratégia é utilizada na tentativa de se evitar ótimos locais.

O algoritmo consiste dos seguintes passos:

1. Um ponto aleatório é escolhido no espaço. Esse ponto é avaliado e ele se torna o ponto corrente.

2. Um de seus vizinhos é sorteado e avaliado.

3. Se a avaliação do vizinho for superior ao do ponto corrente, ele passa a ser o ponto corrente;

4. Se a avaliação do vizinho for inferior a do ponto corrente, ele ainda tem a probabilidade $\mathrm{x}$ de se tornar o ponto corrente;

5. O valor de $\mathrm{x}$ é reduzido, de acordo com alguma política e o algoritmo volta para o passo 2. 
A maneira como o valor de x é reduzido de iteração para iteração é definido como "curva de resfriamento", ainda em analogia a têmpera do aço. Essa curva pode ser logarítmica, polinomial, ou qualquer outra, desde que chegue ao valor zero no final do processo.

O valor de $\mathrm{x}$ deve ser zero ao fim do processo, porque enquanto a variável não for zero, existe a possibilidade de o algoritmo sair do ponto de máximo local. Sendo que, ao se tornar zero, o algoritmo passa a se comportar como o algoritmo Hill climbing já descrito anteriormente.

\subsection{Computação Evolutiva}

Conforme discutido em (EBERHART; SHI; KENNEDY, 2001), a classe de algoritmos conhecida como algoritmos genéticos, que junto com a tecnologia adaptativa é o principal assunto deste trabalho, está contida no paradigma conhecido como Computação Evolutiva. Esse paradigma pode ser estudado com mais detalhes em (FOGEL, 2005) e difere dos paradigmas tradicionais de busca nos seguintes pontos:

- Utiliza uma população de pontos no processo de busca;

- Utiliza diretamente informações de adequação (fitness) no lugar de funções derivativas;

- Utiliza regras de transições probabilísticas, no lugar de determinísticas.

A combinação das transições probabilísticas junto com a utilização de uma população de pontos no espaço de soluções evita que o algoritmo fique preso em ótimos locais.

Diferentemente da maioria dos algoritmos de busca tradicionais, que sempre partem de um único ponto para outro de forma determinística, muitos pontos de máximo e mínimo são explorados simultaneamente. A direção a ser explorada, apesar de sensível à função de adequação, tem a possibilidade de variar a cada iteração.

Apesar da utilização de transições probabilísticas, a busca realizada não é totalmente aleatória. Ao invés disso, operadores estocásticos combinam e selecionam as soluções, direcionando a busca para as regiões do hiperespaço com maior probabilidade de obter melhores avaliações das funções de adequação. 
Os operadores estocásticos variam de acordo com o algoritmo utilizado. No caso dos algoritmos genéticos, os operadores mais comuns são; a mutação, crossover e o roulette wheel.

A computação evolutiva pode ser dividida de três a quatro grandes áreas, dependendo da literatura, como pode ser visto em (FILHO; ALIPPI; TRELEAVEN, 1993), (POTTER, 1997) e (EBERHART; SHI; KENNEDY, 2001). Basicamente essas áreas são evolution strategies, evolutionary programming e genetic algorithms, sendo que:

evolution strategies (SCHWEFEL, 1965): É uma técnica desenvolvida na Alemanha, na Universidade Técnica de Berlim. Essa técnica foi utilizada para otimizar a aerodinâmica dos corpos. A utilização de ajustes graduais não foi capaz de resolver o conjunto de equações para a redução da resistência do vento, então foram iniciados experimentos com mutações, que realizavam pequenas alterações aleatórias, nas melhores soluções encontradas até o momento, para assim procurar em regiões próximas do hiperespeaço por soluções melhores.

evolutionary programming (FOGEL; OWENS; WALSH, 1966): Trata-se de uma técnica de otimização estocástica similar aos algoritmos genéticos, sua principal diferença consiste em que a única operação genética permitida é a mutação, sem crossover. Essa técnica, desde sua criação tem como principais características a habilidade de evoluir continuamente parâmetros e a capacidade de auto-adaptação. Filosoficamente falando, cada indivíduo da população representa uma espécie inteira, competindo por um nicho no ambiente.

genetic algorithms (HOLLAND, 1975): Nessa técnica cada solução é representada por uma cadeia de símbolos denominada cromossomo. As soluções são recombinadas e alteradas para formar novas soluções. As mais aptas são selecionadas e permanecem nas próximas gerações, concentrando as características de interesse nas soluções geradas pelo algoritmo.

Existe também a área conhecida como genetic programming, apresentada por Friedberg (FRIEDBERG, 1958) (FRIEDBERG; DUNHAM; NORTH, 1959), hoje a literatura se divide nos que consideram essa área autônoma e nos que defendem ser ela uma subárea dos algoritmos genéticos.

Dentre as áreas citadas, a de interesse para o presente trabalho é a dos algoritmos genéticos, (genetic algorithms). 


\section{Algoritmos Genéticos}

Algoritmos genéticos pertencem a uma classe de algoritmos da computação evolutiva que se inspira, de forma primitiva, no processo de evolução natural, derivado da teoria da evolução de Charles Darwin (DARWIN, 1859). Esta técnica teve como um dos pioneiros John Holland que vinha trabalhando na área de sistemas adaptativos desde os anos 1960 e teve como uma das publicações mais importantes, sobre o assunto, o livro "Adaptation in Natural and Artificial Systems" (HOLLAND, 1975).

Segue uma descrição resumida do algoritmo, que servirá como base para as implementações do trabalho. Mais à frente cada passo será descrito em maiores detalhes.

Como dito anteriormente, os algoritmos genéticos consistem, entre outras coisas, em um conjunto de pontos no espaço, que representam soluções em potencial para um determinado problema de busca ou otimização. Cada um desses pontos é considerado um indivíduo da população e possui uma representação através de um ou mais cromossomos, no caso de representações diplóides, triplóides ou superiores. O conjunto de cromossomos que define um indivíduo, no presente trabalho, é denominado genoma.

A cada momento, o algoritmo possui um conjunto de indivíduos denominado geração. A cada um desses indivíduos é aplicada uma função de adequação que o avalia através de uma nota. A nota recebida por cada indivíduo é utilizada no processo de seleção, e será utilizada para determinar a partir de quais indivíduos será produzida a nova geração de soluções.

A produção de uma nova geração é realizada através do agrupamento dos indivíduos em pares. Estes pares, inspirados na reprodução sexuada, recombinam seus cromossomos, gerando novos indivíduos a serem avaliados, selecionados e que novamente serão recombinados, dando prosseguimento ao processo de evolução.

Esse procedimento é repetido até que algum critério de parada seja satisfeito. 


\section{$5.1 \quad$ Ambiente}

No presente trabalho, o ambiente é considerado o conjunto formado pela população das soluções, os casos de teste e a forma através da qual os indivíduos são submetidos a esses casos de teste, avaliados e selecionados para a formação de uma nova geração.

\subsection{Genoma}

A definição do conjunto de cromossomos que determina as características do indivíduo, o genoma, é considerada uma das atividade mais críticas no processo de desenvolvimento de uma solução que utiliza algoritmos genéticos.

Neste trabalho, optou-se pela utilização do termo genoma no lugar de, simplesmente, cromossomo, porque foram utilizadas codificações diplóides nos experimentos realizados. Organismos diplóides possuem mais de um cromossomo, daí a utilização do termo genoma, para se referir ao conjunto de cromossomos que define o indivíduo.

De forma empírica, é possível notar que a definição do formato do cromossomo tem forte influência no desempenho da solução, sendo um alvo muito interessante de futuros estudos.

Tradicionalmente, o formato do cromossomo é definido sobre uma cadeia de 0's e 1's, porém há conhecimento de experimentos com cadeias com mais de dois tipos de elementos (MOSTAFAVI, 2006). A cada posição específica na cadeia do cromossomo é dado o nome de alelo ou gene.

A idéia, na definição do formato do cromossomo, é identificar todas as dimensões do hiperespaço de soluções e representar essas variáveis através de um conjunto, contíguo ou não, de posições específicas na cadeia de genes do cromossomo.

Por exemplo, seja um espaço de busca de uma determinada solução, definido em apenas duas dimensões e que cada dimensão possui valores entre 0 e 255 cada uma. Para esse exemplo, pode-se definir o cromossomo como uma cadeia de dezesseis bits, sendo que os oito primeiros bits definem o espaço de busca da variável referente a uma dimensão e os oito últimos bits definem o espaço de busca da variável referente a outra dimensão.

Posta essa forma de abordar o problema da definição do formato do cromos- 
somo, fica evidente uma limitação na capacidade desse algoritmo, pois é necessário limitar o espaço de busca, para utilizar uma representação finita das possíveis soluções para o problema em questão.

Assim, no exemplo acima, se a melhor solução possível para o problema estivesse em uma região em que uma das dimensões possuísse valor superior a 255 , essa solução não seria encontrada.

Como solução para essa limitação, é bastante natural pensar em utilizar uma representação variável para o cromossomo, de forma que a representação das soluções nas cadeias de genes cresça durante a execução do algoritmo, se for necessário. De fato, há notícias de estudos com cromossomos de tamanho variável e com quantidade variável de cromossomos. O próprio John Holland em (HOLLAND, 1975) incluiu propostas para a adaptação da codificação genética das soluções, porém o presente trabalho não aborda essa possibilidade, deixando para uma etapa futura desse estudo.

\subsection{Geração}

O conceito de geração, definida pelos algoritmos genéticos, é o conjunto de indivíduos em um determinado momento da execução do algoritmo. Ao final da avaliação de todos os indivíduos de uma determinada geração, a seleção desses indivíduos é realizada e a partir dos indivíduos selecionados é produzida uma nova geração, para ser submetida ao ambiente e avaliada novamente(EBERHART; SHI; KENNEDY, 2001).

\subsubsection{Geração inicial}

A geração inicial, a primeira população do algoritmo, varia de acordo com a implementação. Normalmente a primeira geração é iniciada com seus cromossomos definidos aleatoriamente, ou seja, são gerados vários pontos no hiperespaço para dar início à busca por uma solução(EBERHART; SHI; KENNEDY, 2001).

Há casos em que a população é iniciada com características genéticas prédeterminadas, de forma a garantir que a população possuirá determinadas características.

Ao invés de iniciar a população inteira com características pré-determinadas, pode-se iniciar apenas alguns de seus membros, sendo que o restante da população é iniciado de maneira aleatória, para que o algoritmo não perca suas 
características exploratórias pelo hiperespaço.

\subsection{Operações Genéticas}

As operações genéticas são operações que ocorrem nos cromossomos dos indivíduos. Seu objetivo é combinar e modificar as soluções atuais para formar novas soluções, variando aleatoriamente as características de um determinado indivíduo ou combinando características de dois indivíduos distintos, na tentativa de criar um melhor(MITCHELL, 1996).

\subsubsection{Crossover de ponto único}

Crossover de ponto único é um operador genético que recebe dois cromossomos. Ele, de forma aleatória, determina uma posição na cadeia, o ponto de crossover, que define duas sub-cadeias nos cromossomos a serem combinados. Nessa operação, os cromossomos devem trocar suas sub-cadeias, gerando assim dois novos cromossomos(MITCHELL, 1996).

Por exemplo, sejam dois cromossomos de oito bits, o cromossomo A com o valor 00000000 e o cromossomo B com o valor 11111111. Se de forma aleatória fosse determinado que o ponto de crossover fosse a terceira posição, então os cromossomos resultantes seriam: 00011111 e 11100000 . Um com a sub-cadeia inicial de A concatenada com a sub-cadeia final de B e o outro com a sub-cadeia inicial de B concatenada com a sub-cadeia final de A.

A ocorrência de crossover é determinada por uma probabilidade, cujo valor fica entre 0,65 e 0,8, de acordo com a literatura (EBERHART; SHI; KENNEDY, 2001), sendo definida na configuração do algoritmo.

\subsubsection{Crossover com dois pontos}

Esse operador genético é bastante similar ao crossover de ponto único, porém dois pontos são determinados para realizar o crossover. Com a determinação de dois pontos para o crossover, são geradas três sub-cadeias, a parte inicial, a intermediária e a final. As sub-cadeias intermediárias dos dois cromossomos recebidos pelo operador são trocadas gerando duas novas seqüências(MITCHELL, 1996).

Vale notar que o segundo ponto de crossover pode ser definido em uma posição anterior ao primeiro, isso pode ocorrer porque ambos são definidos aleatoriamente. 
Quando isso ocorre, o comportamento é como se a cadeia que representa o cromossomo estivesse na forma de anel, com seu início ligado ao seu fim. Assim, as sub-cadeias que seriam trocadas entre os cromossomos seriam as sub-cadeias iniciais e finais, deixando a cadeia intermediária fixa.

Por exemplo, sejam dois cromossomos de oito bits, o cromossomo A com o valor 00000000 e o cromossomo B com o valor 11111111. Se os pontos de crossover definidos de forma aleatória fossem a terceira e a quinta posição, então os cromossomos resultantes seriam: 00011000 e 11100111 . Porém se os pontos de crossover fossem a quinta e a terceira posição, então os cromossomos resultantes seriam: 11100111 e 00011000.

\subsubsection{Crossover com múltiplos pontos}

Crossover com múltiplos pontos é similar ao crossover com dois pontos, porém vários pontos são sorteados, no lugar de apenas dois. As sub-cadeias obtidas pelos pontos de crossover nos cromossomos são justapostas alternadamente, gerando os novos cromossomos resultantes da operação(FREGNI, 1997).

\subsubsection{Mutação}

A mutação não visa combinar duas soluções distintas para a criação de uma nova. Este operador recebe apenas um cromossomo e, de forma aleatória, muda o valor de alguns dos genes no cromossomo. A probabilidade para mutação é a mesma para cada posição da cadeia. O valor dessa probabilidade normalmente é bastante baixo, em torno de 0,001 a 0,01, de acordo com a literatura (EBERHART; SHI; KENNEDY, 2001), sendo definido na configuração do algoritmo(MITCHELL, 1996).

É importante notar que probabilidades altas, dentro da faixa indicada acima, ajudam a evitar que os resultados fiquem presos em ótimos locais, pois sempre levam os pontos obtidos a outras regiões do hiperespaço.

Contudo, a ocorrência muito elevada de mutação pode trazer muito ruído aos resultados obtidos, pois cada resultado acabará sofrendo alguma alteração causada pela mutação. Isso pode comprometer a convergência do algoritmo para um resultado satisfatório. Portanto, é importante ter cuidado ao determinar a taxa de mutação, procurando mantê-la dentro dos valores indicados. 


\subsubsection{Mutação Heurística}

Trata-se de uma variação da técnica convencional. Consiste em propagar rapidamente as mutações positivas, ou seja, mutações que proporcionaram benefícios claros para um determinado indivíduo(FREGNI, 1997).

Assim, ao encontrar uma mutação boa, ela é aplicada a todos os indivíduos da mesma família do indivíduo que sofreu a primeira mutação. Dois indivíduos são considerados da mesma família se eles são próximos um do outro no hiperespaço. Para verificar a proximidade, deve ser utilizado algum mecanismo de medida de distância entre as soluções (COLLARD et al., 1998).

\subsubsection{Inversão}

O mecanismo de Inversão é um mecanismo que existe na natureza. Trata-se de um tipo de mutação em que um intervalo é determinado de forma aleatória e a seqüência de bits pertencentes a este intervalo é invertida.

Apesar de existir na natureza, observou-se que os resultados obtidos com essa técnica não foram positivos, tornando-a uma técnica, até o momento, pouco utilizada. Como discutido por Fregni:

"Por existir na natureza, a mutação por inversão tem sido experimentada nos algoritmos genéticos. Contudo, os resultados não têm recomendado essa forma de mutação. Ela consiste em sortear-se um intervalo e inverter-se a seqüência de bits nele existente."(FREGNI, 1997)

\subsection{Incesto}

Incesto é a ocorrência de um indivíduo cruzar com indivíduos da mesma família. Pode-se entender o conceito de família como o de indivíduos próximos no espaço de soluções, conforme discutido em 5.4.5.

A ocorrência de incestos prejudica a diversidade da população gerada pelo algoritmo. No estudo realizado por Craighurst e Martin (CRAIGHURST; MARTIN, 1995) é discutido o impacto do incesto na solução do problema do caixeiro viajante. Nesse estudo, foi determinado que a existência de regras proibindo a ocorrência de incestos melhora as soluções encontradas pelo algoritmo. 


\subsection{Avaliação dos indivíduos}

Baseado no discutido em (EBERHART; SHI; KENNEDY, 2001), a avaliação dos indivíduos é uma das partes mais críticas na implementação de um algoritmo genético. A busca é direcionada através da função de adequação. Por ela é possível determinar alguma pressão evolutiva para que as soluções geradas pelo algoritmo possuam uma determinada característica.

Por exemplo, se o que está sendo buscado pelo algoritmo é o menor autômato finito possível que aceite uma determinada linguagem regular, é necessário considerar o tamanho desse autômato ou a quantidade de transições que ele utiliza durante o cálculo de sua avaliação, de forma que, dados dois autômatos que aceitam a mesma linguagem, o que possuir menor tamanho deve obter uma avaliação superior ao de maior tamanho.

Assim o indivíduo de menor tamanho, por possuir melhor nota, tem melhores chances de permanecer na população na próxima geração e de gerar descendentes com características semelhantes às deles. Assim, as características de interesse, no caso o tamanho do autômato, se tornam mais freqüentes na população.

\subsection{Seleção dos indivíduos}

O processo de seleção visa gerar uma nova população, repetindo as características dos indivíduos da geração passada de forma proporcional à avaliação de cada um desses indivíduos. Assim quanto melhor sucedido for um indivíduo, maiores serão as chances de ele e de seus descendentes estarem presentes nas próximas gerações(MITCHELL, 1996).

\subsubsection{Roulette-wheel}

Um dos métodos mais tradicionais utilizados no processo de seleção é o " roulettewheel" (EBERHART; SHI; KENNEDY, 2001). Esse método consiste em normalizar a nota de todos os indivíduos de uma dada geração e utilizar essa nota normalizada como a probabilidade de cada indivíduo ser escolhido para produzir a próxima geração. Como são normalizadas, a soma de todas as probabilidades deve ser 1.

Pode-se pensar no processo como se fosse determinada uma fatia radial para cada indivíduo em uma roleta, com área proporcional à nota recebida. Assim o indivíduo com a maior área da roleta possuirá a maior probabilidade de ser 
escolhido.

O tamanho da população geralmente é constante e definido no início da execução do algoritmo. Assim em uma população de vinte indivíduos, a roleta seria girada vinte vezes. Como resultado dez casais são formados e através das operações genéticas descritas anteriormente, são gerados vinte descendentes. É importante notar que dessa forma, nada garante que os indivíduos da geração anterior prevalecerão na geração seguinte, assim, uma solução muito bem sucedida poderia se perder nesse processo. Esse fenômeno é conhecido como generation gap.

Para evitar esse tipo de problema, algumas implementações utilizam-se de uma técnica conhecida como elitist strategy ou estratégia elitista. Essa técnica consiste em copiar uma porcentagem da população anterior, contendo os indivíduos mais bem sucedidos, para a próxima geração.

\subsubsection{Taxa de normalização}

A Taxa de normalização é uma técnica utilizada por Fregni (FREGNI, 1997),onde os dados a serem normalizados passam por um tratamento de maneira que o maior resultado seja n \% maior que o menor resultado. Esse coeficiente n é a taxa de normalização.

Assim, é definido um valor base b, e o menor resutado obtido, depois de realizado esse tratamento, será convertido para esse valor b, enquanto o maior resultado será convertido para $(100+n) \%$ de b.

O objetivo dessa técnica é garantir que o melhor indivíduo de uma dada geração tenha uma probabilidade, de ser selecionado para gerar a próxima geração, n \% maior a que o pior indivíduo.

A função de transformação utilizada nesse trabalho para tratar os resultados obtidos, baseada no estudo realizado por Fregni (FREGNI, 1997), é:

$$
v_{n}=\frac{n \times b \times\left(v_{a}-v_{p}\right)}{v_{m}-v_{p}}+b
$$

Sendo que:

- $v_{n}$ é o novo valor, após o tratamento;

- n é a taxa de normalização, definida entre 0 e 1;

- b é o valor base; 
- $v_{a}$ é o valor anteiror, antes do tratamento;

- $v_{p}$ é o pior valor obtido da população e

- $v_{m}$ é o melhor valor obtido da população ${ }^{1}$.

Essa técnica traz a vantagem de evitar que saltos evolutivos façam com que a população toda convirja para um único ponto no espaço em poucas gerações, perdendo, dessa forma, as características exploratórias do algoritmo.

\subsection{Teorema de Schema}

O teorema de schema, ou schemata no plural, como pode ser visto em mais detalhes em (EBERHART; SHI; KENNEDY, 2001) e (HOLLAND, 1975), é uma formalização do funcionamento dos algoritmos genéticos.

Schemata são as sub-cadeias relevantes no processo de busca e otimização dos algoritmos genéticos. Cada schema define um subconjunto de cromossomos com valores comuns em determinadas posições de suas cadeias, entre os indivíduos da população. Schema é uma forma através da qual similaridades relevantes entre indivíduos de uma mesma população podem ser descritas e analisadas.

Na representação de um schema, são utilizados os mesmos símbolos utilizados na representação dos cromossomos dos indivíduos, para indicar valores comuns em uma posição específica do cromossomo. Além desses símbolos, é adicionado mais um símbolo especial indicando um valor não definido, um coringa, sendo representado normalmente através dos símbolos '\#' ou '*'.

Por exemplo, para a utilização da representação binária dos cromossomos, pode-se dizer que o alfabeto utilizado na representação dos schemata é o $0,1,{ }^{*}$. Para um cromossomo de comprimento 4, podem ser exemplificados dois schemata, um $* 111$ e o outro $0^{* *} 1$. O primeiro possui duas cadeias que combinam com ele, são elas 0111 e 1111, e o segundo possui quatro cadeias combinando: 0001, 0011, 0101, 0111. Pode-se dizer que os cromossomos que combinam com o schema pertencem ao subconjunto de cromossomos definidos pelo schema.

Holland sugere que o processo de evolução, observado durante a execução dos algoritmos genéticos, pode ser entendido como um processo de formação, disseminação e persistência de schemata. Os schemata que melhor contribuem

\footnotetext{
${ }^{1}$ No caso de $v_{m}=v_{p}$, a transformação não é realizada para a geração em questão.
} 
para uma boa avaliação dos indivíduos de uma população têm melhores chances de estarem presentes nas próximas gerações e em maior quantidade.

Os schemata possuem algumas características relevantes. São elas: o comprimento de definição e sua ordem. O comprimento de definição é a distância entre o primeiro e último elemento com valor específico, por exemplo, ${ }^{* *} 00^{* * *} 01^{* *}$ possui comprimento de definição igual a 6. A ordem de um schema é a quantidade de elementos com valores definidos, no exemplo anterior a ordem do schema é 4 .

A recombinação genética, realizada através de crossover e mutação entre os indivíduos melhor adaptados, contribuem para a descoberta de novos schemata. Apesar disso, a recombinação também acaba quebrando schemata já existentes. Se o ponto de crossover ocorrer no meio de um schema, entre o primeiro e o último valor definido, esse schema será quebrado e não será transmitido para os descendentes desse indivíduo.

Quanto mais compacto o schema, maior a chance de ele permanecer inalterado durante o processo de crossover.

A mutação também possui o papel de buscar por novos shemata, porém não tem o mesmo potencial destrutivo do crossover. Isso ocorre porque a mutação possui uma probabilidade de ocorrência bastante baixa, como discutido anteriormente.

Definido o que é um schema e suas características, foi demonstrado um teorema que prediz a quantidade de vezes que um determinado schema irá aparecer na próxima geração de um algoritmo genético. Esse teorema provê uma forma quantitativa de estimar a permanência de qualquer schema, dada basicamente a avaliação média da população, a avaliação média dos indivíduos que possuem o schema, o comprimento de definição do schema e sua ordem. Porém, os cálculos assumem certas configurações do algoritmo genético, que consiste no método de seleção roulette-whell sem nenhum tipo de estratégia elitista, com operadores genéticos crossover e mutação simples, entre outras coisas.

É importante notar que esse teorema pode ser utilizado apenas para realizar análises quantitativas de algumas características que estão sendo passadas de geração para geração, no decorrer da evolução da população, na execução do algoritmo. Esse teorema não determina a qualidade ou velocidade que o algoritmo irá resolver um determinado problema. Apesar de ser um assunto que não foi totalmente aceito na comunidade de computação evolutiva, é uma abordagem formal, quantitativa e bastante interessante para os algoritmos genéticos. 


\subsection{Critério de parada}

O procedimento descrito do algoritmo genético é repetido até que algum critério de parada seja alcançado, conforme discutido em (EBERHART; SHI; KENNEDY, 2001) e (FREGNI, 1997). Por exemplo:

- quando a nota média da população alcançar um determinado patamar;

- quando a nota de pelo menos um grupo de indivíduos alcançar esse patamar;

- quando, depois de um determinado número de gerações, não houver mais uma evolução clara nas avaliações dos indivíduos;

- quando, depois de um determinado número de gerações, não houver mais uma evolução clara nas avaliações dos $n$ melhores indivíduos;

- ou quando simplesmente for executado um determinado número de iterações do algoritmo.

Pode-se também adotar o critério de parada any time (FREGNI, 1997), que consiste em deixar o algoritmo sendo executado indefinidamente e só obter a solução do algoritmo quando ela for necessária.

\subsection{Relação de dominância dinâmica}

Como discutido anteriormente e com mais detalhes em (GOLDBERG, 1989), é possível realizar representações diplóides das soluções(MITCHELL, 1996). Ou seja, as soluções possuem dois alelos para cada característica, localizados em dois cromossomos homólogos. Isso pode ser entendido como uma maneira de a natureza manter uma memória genética, para assim introduzir maior diversidade. Com essa memória, algumas características genéticas serão protegidas contra seleções danosas, através de um mecanismo de dominância que mascara um dos genes até que ele venha a ser útil no futuro.

Ao utilizar genomas diplóides ou superiores é necessário definir a diferença entre fenótipo e genótipo. Genótipo é a composição genética total de um indivíduo enquanto fenótipo são as características que esse indivíduo de fato apresenta, normalmente em função de seu genótipo e do ambiente onde ele se encontra. O fenótipo é o que determina a avaliação do indivíduo. 
Quando se trabalha com mais de um alelo para uma determinada característica, a característica final a ser apresentada pelo indivíduo é definida pela combinação desses alelos, dentro de uma relação de dominância.

Esse mecanismo de dominância não possui uma regra clara na computação evolutiva, sendo necessária a criação de uma para tornar viável a utilização de genomas diplóides em algoritmos genéticos. Em (ETANER-UYAR, 1999) é possível encontrar uma proposta para a relação de dominância, assim como em (HILLIS, 1990), porém no presente trabalho foi proposto um mecanismo próprio, que será explicado em maiores detalhes nos capítulos referentes à implementação.

\subsection{Coevolução}

Durante os estudos na área de computação evolutiva, verificou-se a possibilidade da utilização de um recurso conhecido como coevolução. Esse método, discutido por Olsson em 1998 (OLSSON, 1998) pode ser dividido em duas classes, coevolução cooperativa (POTTER, 1997) e coevolução competitiva (ROSIN; BELEW, 1997). A classe que será abordada nesse estudo é a coevolução competitiva, mais precisamente a técnica conhecida como hospedeiro-parasita (HILLIS, 1990).

Essa técnica consiste em utilizar duas populações distintas: uma população de soluções e uma de casos de teste, que irão evoluir em paralelo competindo uma com a outra. Seu objetivo é melhorar o desempenho do algoritmo como um todo.

A coevolução pode ser utilizada nos casos em que a população de soluções é treinada por casos de testes gerados aleatoriamente. Durante a execução do algoritmo observou-se que à medida que os indivíduos se especializavam, a avaliação a que eram submetidos não acompanhava essa evolução, ou seja, os casos de testes não exploravam deficiências nas populações geradas pelo algoritmo, não repetindo os casos em que a população falhava. Dessa forma não há garantias de que esses casos serão estressados no futuro, de maneira que force uma evolução na população.

Hillis (HILLIS, 1990), ao propor o uso de algoritmos genéticos para determinar uma rede de ordenação ótima para listas com dezesseis elementos, percebeu a deficiência do método, ou seja, a falta de orientação na formação dos casos de teste. Para solucionar o caso, buscou na natureza exemplos de organismos que desenvolvem defesas contra parasitas e parasitas que desenvolvem maneiras de burlar as defesas criadas por seus hospedeiros, como em uma corrida armamentista evolutiva (DAWKINS; KREBS, 1979) com adaptações e contra-adaptações. 
Então além dos indivíduos da população representando as soluções (hospedeiros), redes de ordenação, foi proposta a criação de indivíduos que representassem os casos de testes (parasitas), listas de dezesseis elementos a serem ordenadas, de forma que essas duas populações coexistam no mesmo ambiente.

As redes de ordenação (hospedeiros) passaram a receber notas em função do número de casos de testes que conseguiram ordenar, enquanto as listas a serem ordenadas (parasitas) receberam notas em função da quantidade de casos de teste que as redes de ordenação não foram capazes de ordenar.

Assim, no lugar da geração aleatória de casos de testes, o próprio algoritmo gerava listas mais desafiadoras, buscando sempre explorar alguma fraqueza na população das redes de ordenação. Isso ocorre porque os casos de testes que receberam melhores notas eram aqueles que as redes de ordenação tiveram maior dificuldade para ordenar, fazendo com que esses casos de testes prevalecessem na população, sendo repetidos no treinamento das soluções.

Com o aperfeiçoamento da técnica, foram obtidas redes de ordenação melhores do que com as obtidas através da geração aleatória dos casos de testes.

\subsection{Calibração}

O processo de calibração consiste na definição das técnicas que serão utilizadas pelo algoritmo e na definição de seus parâmetros, a fim de se obter os melhores resultados possíveis.

O processo de calibração pode ser dividido em duas partes, a macro-calibração e a micro-calibração, de acordo com Fregni (FREGNI, 1997). O processo de macrocalibração consiste na escolha dos mecanismos a serem aplicados na execução do algoritmo. Por exemplo: Os operadores genéticos, a estrutura cromossômica das soluções, o processo de seleção, a inicialização dos indivíduos da população e a geração dos casos de testes.

A micro-calibração consiste na definição dos parâmetros dos mecanismos selecionados no processo de macro calibração, como taxa de mutação, taxa de sobrevivência dos indivíduos e tamanho da população.

A calibração em si é um processo de otimização, portanto, poderia ser realizada por algoritmos evolucionários, porém permaneceria o problema de como calibrar o algoritmo responsável pela calibração do algoritmo genético inicial.

Como alternatica ao método acima exposto, há metodos mais simples, como 
a subida de encosta ou o Simulated Annealing, que pode ser executado manualmente, contando com o bom senso do pesquisador(FREGNI, 1997). 
Parte III

\section{Implementação}


Nessa seção é explicada a arquitetura da implementação proposta, juntamente com todas as decisões de projeto tomadas. Ainda nessa parte, também é descrito o processo de desenvolvimento de software utilizado neste trabalho e as dificuldades encontradas durante o desenvolvimento. 


\section{Propostas}

Neste capítulo são apresentadas as principais propostas desse trabalho: primeiro é apresentado o algoritmo genético utilizado na inferência de autômatos finitos e adaptativos; em seguida é apresentada a proposta da nova camada adaptativa para autômatos adaptativos.

\subsection{O algoritmo}

Nesse estudo está sendo proposta a utilização de algoritmos genéticos na inferência de autômatos finitos e autômatos adaptativos. Em outras palavras, o algoritmo genético irá procurar a melhor solução, no caso um autômato, que reconheça cadeias pertencentes a uma determinada linguagem.

A inferência ocorre da seguinte maneira: O algoritmo irá manter uma população de indivíduos, cada um representando um autômato, que é uma solução em potencial para o problema.

Várias cadeias da linguagem, para a qual se deseja inferir o autômato, serão submetidas a cada um dos autômatos, ou seja, cada autômato tentará realizar o reconhecimento de diversas cadeias. O quão bem o autômato se saiu no reconhecimento, junto com algumas características, como quantidade de estados, transiçoes e funções adaptativas irão determinar a avaliação de cada solução.

A representação dos autômatos se dá através do genoma, cada um dos candidatos à solução são representados por uma ou mais cadeias de 0's e 1's. Essas cadeias determinam todas as características dos autômatos, como quantidade de estados, transições e quais elementos são aceitos.

Como se trata de um estudo integrando as duas tecnologias, algoritmos genéticos e tecnologia adaptativa, foram realizados vários experimentos, utilizandose de diversas configurações, para verificar qual delas traz melhores soluções.

O funcionamento básico do algoritmo está ilustrado na figura 6.1. Como pode 
ser visto, a partir da primeira geração, os indivíduos são submetidos aos casos de testes (as cadeias da linguagem) e a avaliação média de cada um deles é calculada.

Depois de submetidos aos casos de teste, os indivíduos passam por um processo de avaliação e seleção, que define quais indivíduos irão continuar na próxima geração e quais serão combinados com outras soluções, na tentativa de gerar novas soluções para o problema.

Após selecionados, é iniciado o processo de formação da geração seguinte, copiando os indivíduos sobreviventes para a próxima geração e gerando os novos indivíduos a partir dos antigos. Uma vez formada a nova geração de soluções o processo é repetido, resultando em mais uma geração e assim por diante.

Os mecanismos utilizados em cada passo do processo, como inicialização da geração inicial, a forma de avaliação utilizada, o método de seleção e as operações utilizadas nas combinações das soluções serão descritos em detalhes neste capítulo.

\subsubsection{Representação do cromossomo para a inferência de autômatos finitos}

O passo mais importante na elaboração do algoritmo é a definição da codificação cromossômica dos indivíduos, ou seja, como a combinação dos valores na cadeia de genes irá definir o autômato.

O formato do cromossomo foi baseado em um estudo realizado por Fábera (FÁBERA; JANES; JANESOVA, 2006), porém com algumas mudanças devido a duas principais diferenças em relação ao estudo feito por Fábera:

1. No presente estudo a massa de dados utilizada no treinamento do algoritmo é gerada aleatoriamente e

2. o estudo realizado por Fábera prevê uma cadeia de saída gerada pelo autômato, enquanto neste trabalho o foco é dado apenas na aceitação sintática das cadeias. Para tal, foram adicionados genes para indicar a característica dos estados internos do autômato serem de aceitação ou não.

Para o caso da inferência dos autômatos finitos determinísticos, foi necessário, inicialmente, determinar algumas limitações no espaço de busca, como discutido na seção 5.2, devido à limitação no tamanho da cadeia de genes e à imutabilidade de seu formato.

Portanto, foram definidas as seguintes limitações: 


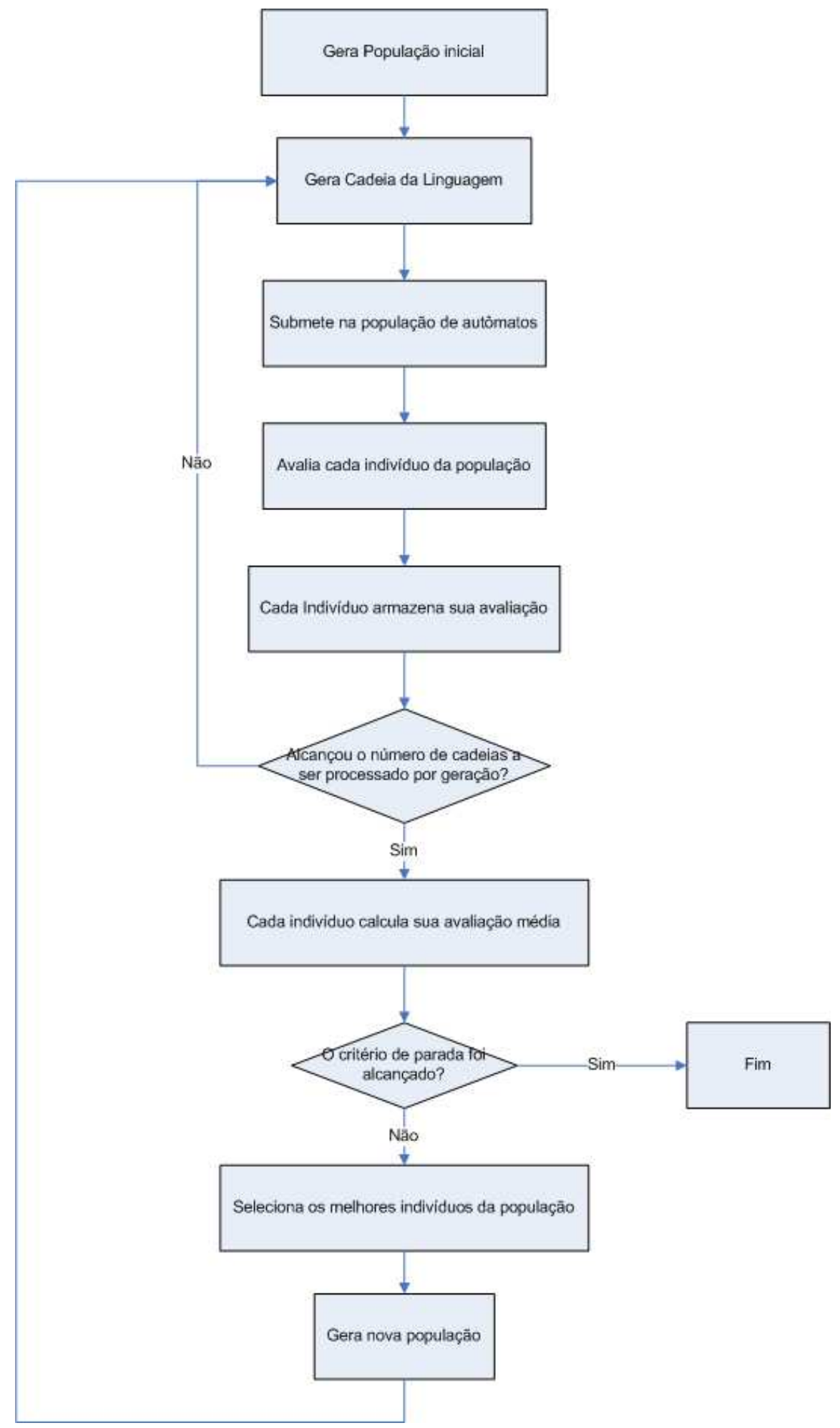

Figura 6.1: Funcionamento do algoritmo proposto. 
1. O autômato pode ter no máximo sete estados;

2. As cadeias de entrada podem ser constituídas por no máximo quatro elementos distintos e

3. por questões de simplicidade, o estado zero é sempre o estado inicial.

O formato do cromossomo é bastante simples, ele é dividido em sete partes iguais, uma para cada estado possível. Cada uma dessas partes é constituída de treze genes, o primeiro indica se o estado é de aceitação ou não, os doze genes restantes são divididos em quatro partes iguais, uma para cada elemento que o autômato pode receber.

Como cada estado é representado por doze genes (descontando o gene que indica aceitação ou não) e o tratamento de cada elemento é representado por um quarto desses genes, então ficam disponíveis três genes para endereçar os estados destinos das transições do autômato, ou sejam, os três primeiro genes identificam qual o estado destino do autômato ao receber o elemento 'a', o segundo grupo de três genes identificam o estado destino do autômato ao receber o elemento 'b' e assim por diante.

Assim, o endereçamento dos estados foi definido da seguinte maneira: em binário, de um a sete estão endereçados os estados de zero a seis, respectivamente. O endereço zero é reservado para indicar que não há transições definidas nesse estado para o elemento em questão, a ilustração na figura 6.2 reforça a explicação.

Vale notar também que, com o formato proposto acima para o cromossomo dos autômatos finitos, não existe a possibilidade de não-determinismos, pois é possível representar apenas uma transição por elemento, dado um estado. $\mathrm{Na}$ figura 6.3 há um exemplo gráfico de um cromossomo.

Com isso o cromossomo do autômato ficou com comprimento de 91 bits.

\subsubsection{Representação do cromossomo para a inferência de autômatos adaptativos}

Na inferência de autômatos adaptativos, a idéia descrita anteriormente, para os autômatos finitos, foi estendida para englobar os mecanismos presentes nos autômatos adaptativos.

Os mecanismos extras, que o autômato adaptativo apresenta, são as representações das funções adaptativas e suas invocações durante o processo de aceitação da cadeia. 


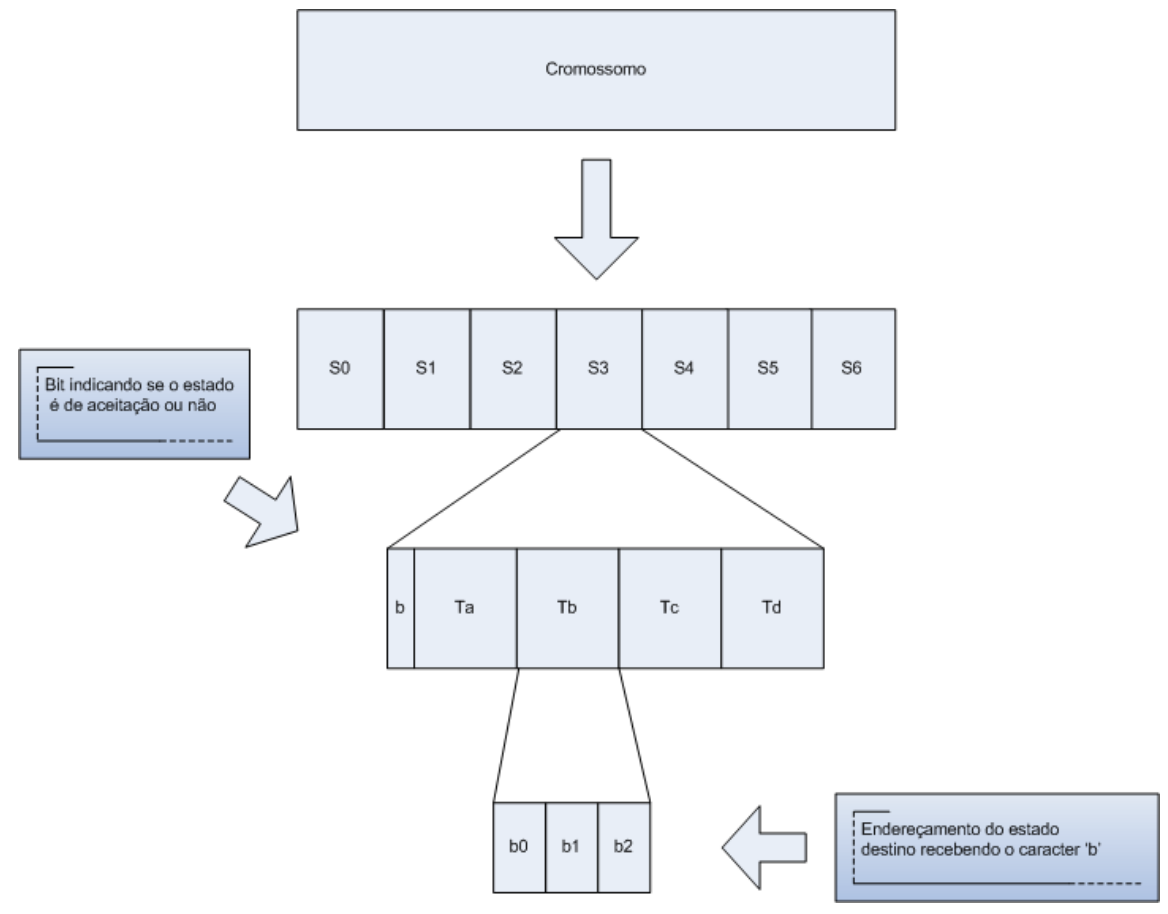

Figura 6.2: Formato do cromossomo para o autômato finito.

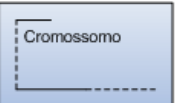

0111000100000000000000000000000000000000000111000000000000000000000000000000001000000000000
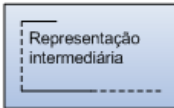

S0: 0111000100000

S1 : 0000000000000

S2: 0000000000000

S3 : 0000111000000

S4 : 0000000000000

S5 : 0000000000000

S6 : 1000000000000

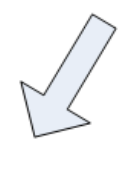


Dessa forma, o novo cromossomo foi dividido em duas partes, uma que descreve as transições do autômato, seguindo a tendência do proposto anteriormente, e a outra que descreve as funções adaptativas.

Mais de um formato foi utilizado nos experimentos. Como no caso dos autômatos finitos, foi necessário determinar limites no espaço de busca devido às limitações na representação cromossômica dos indivíduos. Dessa forma, foi estabelecido que o autômato possuirá no máximo uma função adaptativa e essa função poderá receber, no momento em que for invocada, no máximo quatro parâmetros.

Além dessas limitações, também foi imposto que será utilizada apenas a ação adaptativa pós-transição, isto é, a ação executada somente ao final da transição de estados do autômato. Como nos testes será executada somente a ação adaptativa pós-transição, ela será chamada, daqui para frente, simplesmente como ação adaptativa.

Posto isso, o estado que era representado por 13 bits, 1 indicando se ele era de aceitação e 12 indicando os estados destinos, mudou. No lugar de apenas endereçar o estado destino da transição, também será necessário informar se a ação adaptativa será usada e quais os argumentos que serão passados.

Como está disponível apenas uma função adaptativa, é utilizado apenas 1 bit indicando se a transição possui características adaptativas ou não, ou seja, se ela invoca a função adaptativa durante sua execução ou não. Em estudos futuros, quando houver mais funções adaptativas, no lugar de apenas 1 bit serão utilizados mais bits, endereçando as funções utilizadas e mantendo o valor 0 reservado, para o caso de a transição não ser adaptativa.

Além do bit indicando a invocação da função adaptativa, serão acrescentados mais 12 bits, que representam os parâmetros passados na função. Nesse estudo inicial sobre o assunto, ficou definido que os únicos valores passados por parâmetro para a função adaptativa serão os estados do autômato.

Assim, como o autômato inicialmente possui no máximo 7 estados e o número máximo de parâmetros é quatro, são necessários 12 bits para os parâmetros, quatro grupos de três bits endereçando os estados do autômato.

Conforme ficou definido na codificação dos autômatos finitos, se não houver transição alguma saindo de um estado e nenhuma transição chegando a esse estado, então esse estado não existe no autômato, ele não está ativo.

Se um estado que não estiver ativo for passado como parâmetro para uma 


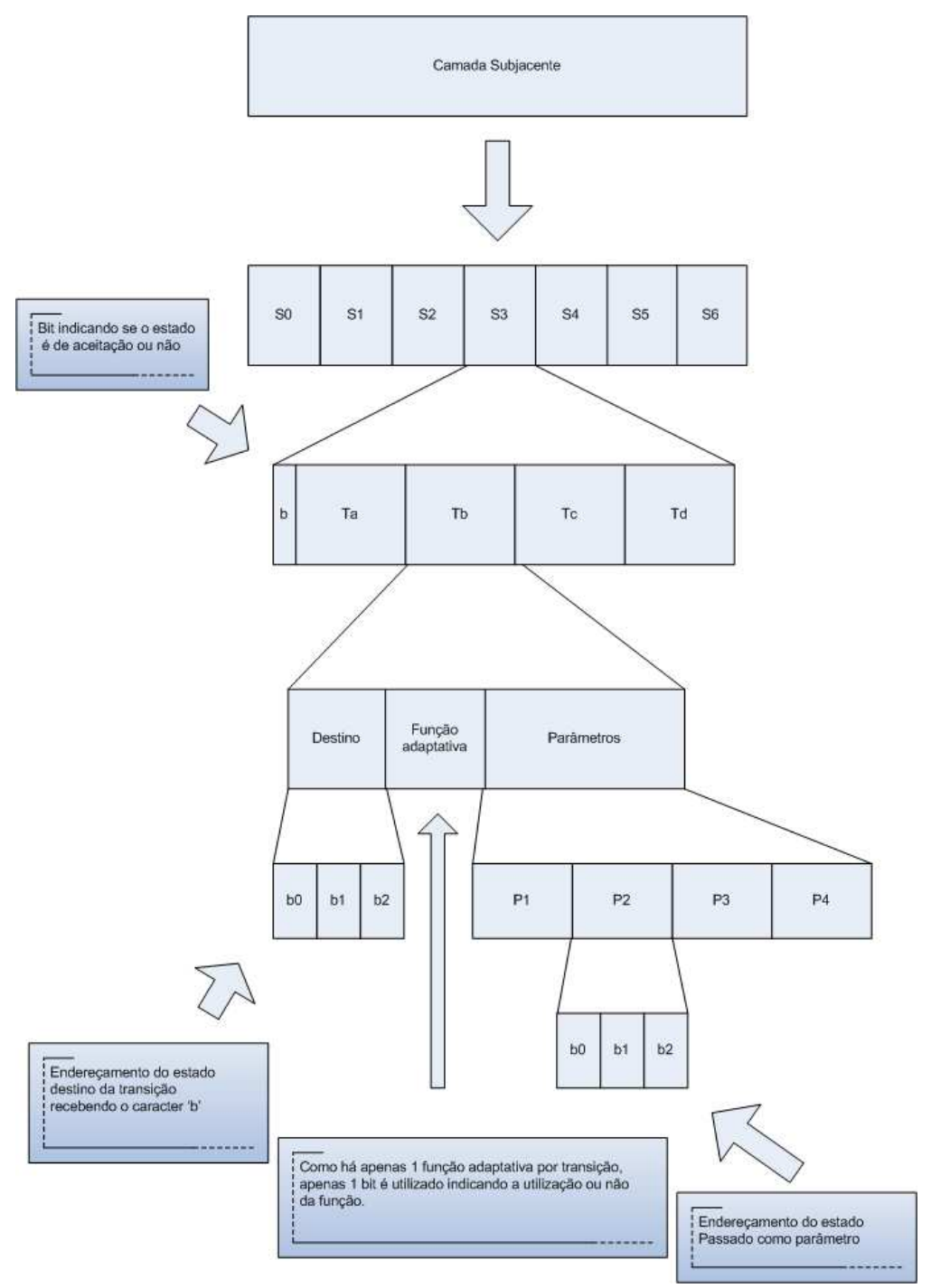

Figura 6.4: Formato da região do cromossomo que codifica a camada subjacente do autômato adaptativo.

função, esse parâmetro não é considerado, de maneira que o próximo grupo de três bits toma o lugar dele na lista de parâmetros. Assim, se, ao invocar a função, todos os estados passados para a função estiverem inativos, essa chamada não possuirá parâmetros.

A codificação do cromossomo para as transições dos autômatos adaptativos está ilustrada na figura 6.4.

Além do trecho representando o autômato em si, há o trecho que representa as ações adaptativas, um espaço apenas para descrever funções.

Dentro das limitações a serem impostas no espaço de busca para os autômatos, ficou decidido que a função, além de receber no máximo 4 parâmetros, possui no máximo 4 variáveis, 4 geradores e é formada por no máximo 8 ações adaptativas elementares. 
Conforme exposto na seção 3.3, as ações adaptativas elementares possuem o mesmo formato das regras de formação dos dispositivos subjacentes, no caso, uma transição de estados.

Assim, a representação da função é dividida em 8 blocos de comprimentos iguais, um para cada ação adaptativa elementar. Os dois primeiros bits representam o tipo de ação, conforma a tabela 6.1.

Tabela 6.1: Relação de valores na codificação dos tipos de ações adaptativas elementares

\begin{tabular}{|c|c|}
\hline \hline Tipo & Valor \\
\hline Inativo & 0 \\
\hline Consulta & 1 \\
\hline Remoção & 2 \\
\hline Inserção & 3 \\
\hline \hline
\end{tabular}

Os quatro bits seguintes determinam o estado de origem da transição. Ficou determinado que as ações elementares nunca farão referência direta aos estados pertencentes ao autômato, a referência sempre ocorrerá através dos parâmetros ou variáveis da função, assim, o estado origem da transição é representado por 4 bits, 2 indicando o tipo de variável, conforme a tabela 6.2 , e 2 bits endereçando a variável, sendo que há quatro de cada tipo.

Tabela 6.2: Relação de valores na codificação dos tipos de variáveis das funções adaptativas

\begin{tabular}{|c|c|}
\hline \hline Tipo & Valor \\
\hline Inativo & 0 \\
\hline Gerador & 1 \\
\hline Parâmetro & 2 \\
\hline Variável & 3 \\
\hline \hline
\end{tabular}

Os dois bits seguintes identificam o símbolo recebido da cadeia de entrada, como nesse caso há apenas quatro símbolos distintos, são usados apenas 2 bits. Vale notar que esses símbolos não podem ser representados por variáveis.

Os quatro bits seguintes identificam o estado destino da transição. Para esse elemento é utilizado o mesmo formato do estado de origem. Em seguida ao estado destino, há um bit que indica a utilização ou não da função adaptativa durante a transição.

Por último, há uma lista com quatro parâmetros a serem passados para a função adaptativa, também respeitando a codificação utilizada nos estados de origem e destino da transição, ou seja, os parâmetros são representados por variáveis. 


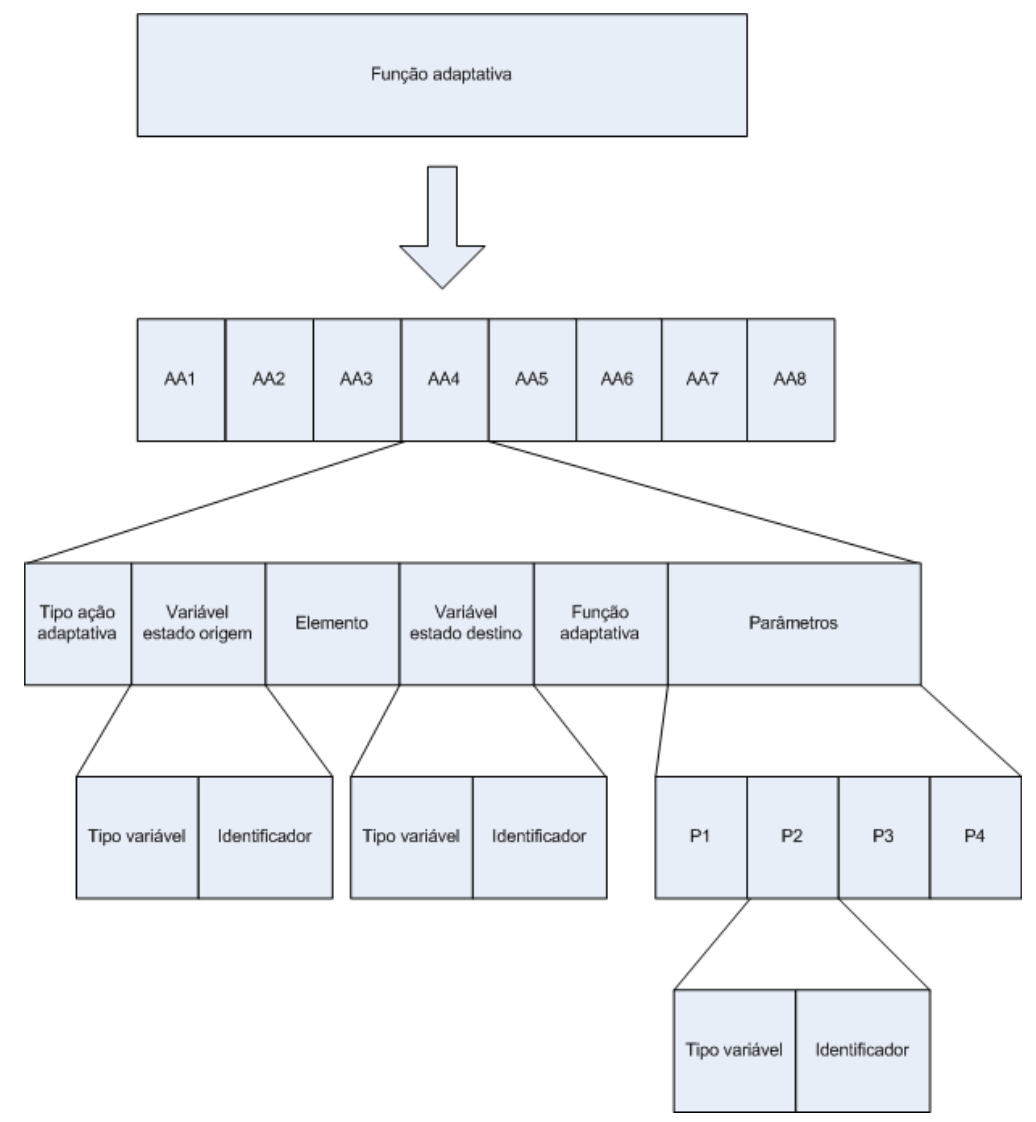

Figura 6.5: Formato da região do cromossomo que codifica a camada adaptativa do autômato adaptativo.

A figura 6.5 ilustra o formato do trecho do cromossomo que descreve as funções adaptativas.

\subsubsection{Não-determinismos no autômato adaptativo}

Com a execução das ações adaptativas, surge a questão do tratamento de nãodeterminismos no autômato, situação que não era possível na inferência dos autômatos finitos.

Seguindo rigorosamente o conceito de não-determinismo, seria necessário abrir uma ou mais threads para cada não-determinismo encontrado no autômato, durante a aceitação da cadeia.

Essa abordagem, apesar de correta, não se mostra viável, uma vez que a quantidade de não-determinismos encontrados pode ser muito grande, com isso, a quantidade de recursos de processamento e memória necessária para a execução de cada indivíduo pode fazer com que o algoritmo não encontre uma solução satisfatória em tempo hábil.

Assim, para manter o algoritmo viável, foi introduzido mais um mecanismo 


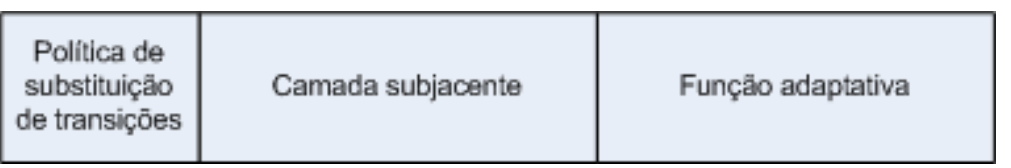

Figura 6.6: Formato final do cromossomo do autômato adaptativo.

no cromossomo dos autômatos adaptativos. Esse mecanismo define o comportamento do autômato, caso ocorra a introdução de não-determinismos no mesmo, durante o processo de adaptação.

Para os casos em que ações adaptativas tentam inserir uma transição em um estado para um elemento que já estava previsto por outra transição, foi criado um gene que indica se o autômato deve substituir a transição antiga pela nova ou ignorar a inserção da nova transição.

Esse gene ficou definido como o primeiro gene do cromossomo, conforme a figura 6.6 ilustra.

\subsubsection{Inicialização da população}

No caso da inferência de autômatos finitos, verificou-se que inicializar a população com todos os bits em zero aumenta a tendência de o algoritmo convergir para soluções mais eficientes, uma vez que, com todos os bits em zero, todos os estados e transições estão desabilitados. Assim, apenas as transições habilitadas por mutação e que contribuem para a aceitação da cadeia tendem a permanecer na população.

Porém verificou-se que a aplicação de outras técnicas, como contra-exemplos e estratégias elitistas, também contribuem para a obtenção de autômatos mais eficientes, com a vantagem de não perder as características exploratórias dos algoritmos genéticos.

Além disso, não foi identificado schema algum que, para qualquer linguagem, garantisse um bom desempenho dos indivíduos. Posto isso, foi decidido sempre iniciar a população de forma aleatória.

\subsubsection{Geração de cadeias}

A geração das cadeias foi implementada de forma que as cadeias produzidas, pertencentes às linguagens alvo, sejam aleatórias. Para a inferência de autômatos finitos, foram utilizadas apenas linguagens regulares nos testes. 
A geração aleatória das cadeias, a partir de expressões regulares, ocorre através da relação entre os símbolos comuns à expressão regular, como '*', '+' e 'l', e um conjunto de regras indicando como proceder ao processar cada símbolo, conforme descrito na tabela 6.3.

Os símbolos são processados de forma recursiva, e os resultados do processamento são concatenados em uma cadeia de saída, que é retornada no fim do processo de geração.

Para a definição das regras de geração, foi necessária a definição de uma função rand(), que retorna um número aleatório do tipo ponto flutuante, entre 0 e 1, e de uma função round(f), que retorna o inteiro mais próximo, dado um número do tipo ponto flutuante.

Tabela 6.3: Regras para a geração de cadeias de uma linguagem

\begin{tabular}{|c|l|}
\hline \hline Símbolo & Ação \\
\hline exp & $\begin{array}{l}\text { A expressão exp é adicionada na cadeia de } \\
\text { saída, sem componentes aleatórios para esse } \\
\text { caso. }\end{array}$ \\
\hline$(e x p) *$ & $\begin{array}{l}\text { Adiciona a expressão exp a quantidade de } \\
\text { vezes retornada pela expressão round(rand() } \\
* \text { n) na cadeia de saída, sendo n um inteiro } \\
\text { definido na configuração do algoritmo. }\end{array}$ \\
\hline$(\exp )+$ & $\begin{array}{l}\text { Adiciona a expressão exp a quantidade de } \\
\text { vezes retornada pela expressão round(rand() } \\
* \text { n) }+1 \text { na cadeia de saída, sendo n um } \\
\text { inteiro definido na configuração do algoritmo. }\end{array}$ \\
\hline $\exp _{1}\left|\exp _{2}\right| \ldots \mid \exp _{n}$ & $\begin{array}{l}\text { Divide-se o intervalo de 0 a 1 em n fai- } \\
\text { xas iguais, uma para cada possibilidade, e } \\
\text { adiciona-se na cadeia de saída a expressão } \\
\text { regular de acordo com a faixa que o valor } \\
\text { retornado por rand() estiver contido. Sendo } \\
\text { que, se o valor aleatório estiver na primeira } \\
\text { faixa de valores, será adicionada a expressão } \\
\exp _{1} \text {, se ele estiver na segunda, será adicio- } \\
\text { nado a exp e assim por diante. }\end{array}$ \\
\hline \hline
\end{tabular}

\subsubsection{Linguagens com aninhamentos sintáticos}

Para a inferência de autômatos adaptativos, foram utilizadas linguagens livres de contexto, que apresentam aninhamentos sintáticos. A geração de linguagens com aninhamentos sintáticos foi obtida através da introdução de variáveis na expressão regular. Essas variáveis representam a quantidade de vezes que uma determinada expressão será repetida. 
Basicamente a variável substitui o símbolo '*', pois ela representa um número aleatório. A diferença é que caso essa variável seja utilizada para indicar a repetição de outro elemento na expressão regular, esse outro elemento será repetido o mesmo número de vezes que o primeiro.

Com esse mecanismo é trivial a representação de aninhamentos, por exemplo, a expressão $a^{n} b c^{n}$, indica que as expressões 'a' e 'c' repetem um número aleatório de vezes, porém esse número é o mesmo nos dois casos, uma vez que as quantidades de repetições são representadas pela mesma variável.

\subsubsection{Coevolução}

Para aplicar esse mecanismo na inferência de autômatos, foi necessário alterar o ambiente, de forma que o conjunto de casos de testes não fosse mais criado aleatoriamente, mas que fosse determinado por uma população de cadeias a ser submetida à população de autômatos.

Assim, o ambiente passa a possuir duas populações, uma de autômatos e uma de cadeias. Cada indivíduo, na população de cadeias, realiza o papel de parasita em relação aos autômatos, de maneira que sua avaliação é dada em função da avaliação dos autômatos. Dada a nota máxima possível a ser alcançada por um autômato, a nota da cadeia será 1 menos a relação da nota média, obtida pelos autômatos no processamento dessa cadeia, pela nota máxima possível de ser alcançada.

$$
\text { nota cadeia }=1-\frac{\text { nota media automatos }}{\text { nota maxima automatos }}
$$

Com essa implementação, quanto maior a nota dos autômatos, mais baixa a nota da cadeia, e vice-versa. Assim, as populações de autômatos e cadeias evoluem de forma competitiva, sendo que a população de cadeias busca obter avaliações melhores sempre explorando deficiências nos autômatos gerados pelo algoritmo.

Utilizando a coevolução, o algoritmo passe a ter o funcionamento conforme descrito na figura 6.7 .

\subsubsection{Geração de cadeias}

A geração de cadeias, propriamente dita, é feita de forma semelhante à geração aleatória, descrita anteriormente, porém o componente aleatório representado pela função rand() é substituído pela codificação genética dos indivíduos, de ma- 


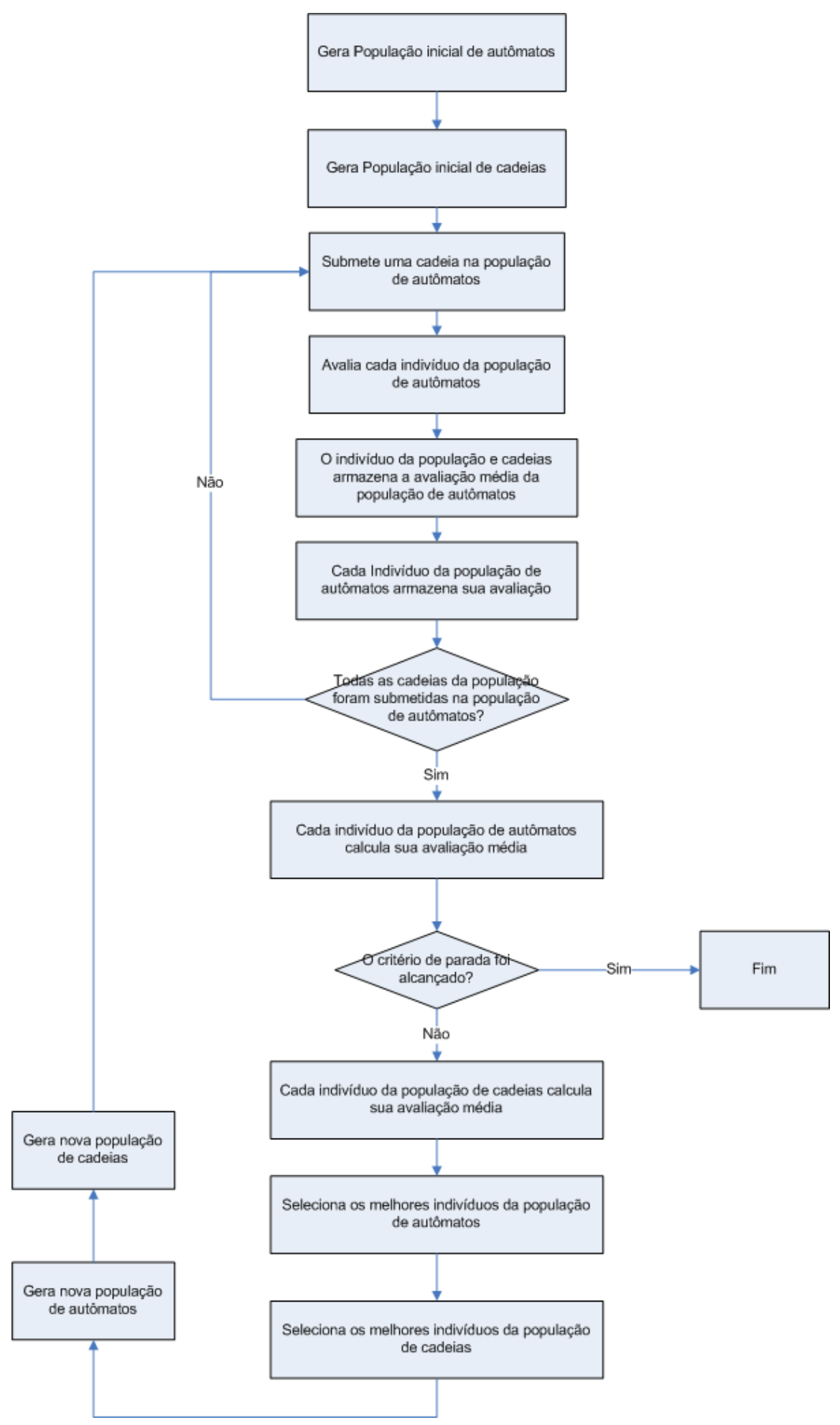

Figura 6.7: Funcionamento do algoritmo proposto com coevolução. 
neira que um genoma sempre representa apenas uma cadeia.

A decodificação genética do genoma em cadeias é feita de forma diferente para cada linguagem, ou seja, para cada linguagem a ser inferida, será utilizada uma formatação específica para o cromossomo.

Na tabela 6.4 constam as novas regras para a geração das cadeias:

Tabela 6.4: Regras para a geração de cadeias de uma linguagem a partir do genoma de um indivíduo

\begin{tabular}{|c|l|}
\hline \hline Símbolo & Ação \\
\hline exp & $\begin{array}{l}\text { A expressão exp é adicionada na cadeia de } \\
\text { saída, sem componentes aleatórios para esse } \\
\text { caso. }\end{array}$ \\
\hline$(e x p) *$ & $\begin{array}{l}\text { Adiciona n vezes a expressão exp na cadeia } \\
\text { de saída, sendo n um inteiro definido de } \\
\text { forma binária, por um conjunto fixo de ge- } \\
\text { nes pertencente ao genoma do indivíduo. }\end{array}$ \\
\hline$(\exp )+$ & $\begin{array}{l}\text { Adiciona } \mathrm{n}+1 \text { vezes a expressão exp na ca- } \\
\text { deia de saída, sendo n um inteiro definido de } \\
\text { forma binária, por um conjunto fixo de genes } \\
\text { pertencente ao genoma do indivíduo. }\end{array}$ \\
\hline$e_{1}\left|p_{2}\right| p_{2}|\ldots| e x p_{n}$ & $\begin{array}{l}\text { Adiciona uma das expressões na cadeia de } \\
\text { saída, em função de um número x que é co- } \\
\text { dificado utilizando log } n \text { genes do genoma do } \\
\text { indivíduo. Sendo que para x }=0, \text { será adici- } \\
\text { onada a expressão exp } \text {, se x }=1 \text { será adici- } \\
\text { onada a exp } p_{2} \text { e assim por diante. Procura-se } \\
\text { evitar faixa de valores inválidos, que ocorrem } \\
\text { quando não existe um número natural m de } \\
\text { forma que } n=2^{m} \text {. Na ocorrência dessas } \\
\text { faixas, são escolhidas algumas das alternati- } \\
\text { vas para serem beneficiadas, fazendo com que } \\
\text { elas possuam mais de um número correspon- } \\
\text { dente. }\end{array}$ \\
\hline \hline
\end{tabular}

\subsubsection{Seleção}

O processo de seleção é fortemente baseado no funcionamento da função de avaliação, à qual as soluções geradas no processo são constantemente submetidas.

Foi utilizado o roulette-wheel como método de seleção, porém além do problema do generation gap, discutido em 5.7.1, que ocorre quando a taxa de sobrevivência é zero, foi verificado durante o estudo outra dificuldade na utilização desse método.

Quando ocorre um salto evolutivo, ou seja, surge um indivíduo com avaliação 
muito superior ao restante da população, esse indivíduo acaba predominando quase absolutamente nas gerações seguintes.

Por exemplo, se toda a população recebeu notas entre 0 e 10 e apenas um indivíduo recebeu uma nota acima de 1000. Isso provocará uma tendência muito forte que apenas esse indivíduo seja escolhido para formar a próxima geração.

Apesar de ser bom que as características de interesse se espalhem rapidamente pela população, existe o problema do ótimo local. Quando a população se torna homogênea muito rapidamente, o algoritmo perde a sua característica de explorar diversos pontos simultaneamente. Assim todos os pontos espalhados pelo hiperespaço, em poucas iterações, passam a se concentrar apenas em uma região, deixando o algoritmo preso no possível ótimo local que causou a nota alta do primeiro indivíduo.

É possível evitar esse tipo de problema tomando-se cuidados na elaboração da função de adequação, evitando que variações muito drásticas na avaliação da população ocorram. Caso não seja possível evitar fortes variações nas avaliações dos indivíduos, é possível utilizar o conceito de "taxa de normalização" visto em 5.7.1.1.

Uma alternativa seria alterar o método de seleção dos indivíduos, não favorecendo tanto os indivíduos mais bem sucedidos.

Os métodos de seleção utilizados no algoritmo foram o roulette-wheel e um método de seleção não estocástico, proposto a seguir.

\subsubsection{Seleção não estocástica}

Como alternativa ao roulette-wheel foi proposto um método mais simples e com menos componentes aleatórios, que procura espalhar as características de interesse pela população de forma mais controlada.

O método consiste em ordenar os indivíduos da população em função de suas notas. Uma vez ordenadas, as n \% melhores soluções são copiadas para a próxima geração e as m \% melhores soluções são agrupadas de duas em duas para gerar novos indivíduos, para completar a próxima população, de maneira que $\mathrm{m} \%+$ n $\%=100 \%$.

A formação dos grupos de dois indivíduos feitos dos $\mathrm{m} \%$ melhores indivíduos é realizada de forma estocástica, sendo esse o único elemento aleatório do método.

Com este método, a geração seguinte pode conter no máximo duas cópias do 
indivíduo melhor sucedido da geração passada, uma realizada pela cópia dos n \% melhores indivíduos e a outra pela combinação dos genomas dos $\mathrm{m} \%$ melhores indivíduos, uma vez que nessa última há uma probabilidade de as operações genéticas, como crossover e mutação, não ocorrer.

\subsubsection{Avaliação das soluções}

A definição da função responsável pela avaliação das soluções não é tarefa simples. Em primeiro lugar deve-se decidir o quanto uma solução é melhor que outra. Como o aplicativo tem a função de gerar autômatos, a questão se reduz a como decidir se um autômato é melhor que outro na aceitação de uma determinada linguagem.

Através do processo de avaliação é que a busca por soluções será direcio-

nada para o local desejado no espaço de busca. É muito importante atenção ao desenvolver a função de avaliação para evitar ótimos locais.

De forma geral, foi percebido que a regra para a avaliação das soluções é bastante simples. As características desejadas devem ser recompensadas com notas mais altas em relação a características indesejadas.

Porém, observa-se que é importante ter cuidado ao se adotar essa estratégia, por exemplo, no caso dos autômatos adaptativos, é interessante que o algoritmo calcule um autômato adaptativo mais simples possível, que possa ser compreendido por outras pessoas, sem possuir ações adaptativas desnecessárias, que só dificultariam a análise do modelo.

Pensando nisso, foi adicionada, à avaliação dos autômatos, a verificação da quantidade de ações adaptativas utilizadas por suas funções adaptativas. O obtido como resultado é que os autômatos tiveram a tendência de não apresentar ações adaptativas em suas funções.

Esse resultado ocorreu porque as funções adaptativas, presentes inicialmente na população de autômatos, não proporcionavam uma vantagem evolutiva real. Isso porque as funções adaptativas foram iniciadas aleatoriamente e não conseguiram ajudar o autômato a reconhecer as cadeias da linguagem livre de contexto.

Assim, mesmo sem reconhecer a linguagem, o algoritmo erroneamente dava preferência para autômatos sem ações adaptativas, pois esses apresentavam avaliações melhores que os autômatos que as possuíam.

Então, o fato de a avaliação depender da quantidade de ações adaptativas 
nas funções adaptativas estava inibindo o desenvolvimento das características adaptativas do autômato.

Como solução para essa questão, a quantidade de ações adaptativas passou a ser considerada apenas nos casos em que o autômato já aceita a linguagem, pois dessa forma, enquanto os autômatos não estiverem aceitando a linguagem, eles poderão experimentar livremente diversas combinações de ações adaptativas.

Uma vez encontrada uma combinação de ações adaptativas que proporcione uma vantagem evolutiva para os indivíduos, a quantidade de ações adaptativas presentes nas funções passará a ser considerada, para que a função seja otimizada ao máximo.

Se, durante o processo de otimização da função adaptativa, ocorrer a remoção de alguma ação importante para a aceitação da linguagem, a função deixará de proporcionar vantagens evolutivas para o indivíduo. Isso fará com que ocorra uma redução de sua avaliação. Dessa maneira, esse indivíduo ficará em desvantagem no processo evolutivo, sendo removido da população nas gerações seguintes.

Assim, a otimização da função adaptativa ocorre sem o risco de o autômato ficar sem ações adaptativas, mesmo considerando a quantidade de ações no processo de avaliação.

\subsubsection{Avaliação dos autômatos finitos}

A avaliação dos autômatos finitos é realizada através da seguinte função de adequação:

adequação $=a+b \times(c+d+e \times(f+g))$.

sendo que:

$a=\frac{\text { quantidade de elementos computados }}{\text { quantidade de elementos na cadeia }} \times \alpha$.

$\mathrm{b}=\{\mathrm{n}: \mathrm{n}=1$ se o autômato computou toda a cadeia e $\mathrm{n}=0$ no caso contrário\}.

$$
\begin{aligned}
& c=\frac{\text { quantidade de transicoes utilizadas pelo automato }}{\text { quantidade de transicoes utilizadas no automato }} \times \beta . \\
& d=\left(1-\frac{\text { quantidade de estados do automato }}{\text { quantidade maxima possivel de estados }}\right) \times \gamma . \\
& \mathrm{e}=\{\mathrm{n}: \mathrm{n}=1 \text { se o autômato terminou o processamento em um estado de }
\end{aligned}
$$
aceitação e $n=0$ no caso contrário $\}$.

$$
f=\left(1-\frac{\text { quantidade de transicoes noautomato }}{\text { quantidade maxima de transicoes no automato }}\right) \times \delta
$$


$g=\left(1-\frac{\text { quantidade de estados de aceitacao }}{\text { quantidade de estados do automato }}\right) \times \epsilon$.

Os coeficientes $\alpha, \beta, \gamma \delta e \epsilon$ são pesos definidos na configuração do algoritmo.

Através dos pesos citados acima, tanto no caso do autômato finito quanto no caso do autômato adaptativo, exposto na seção 6.1.7.2, é possível privilegiar uma determinada característica de interesse por vez. Com isso é possível sugerir a direção que o algoritmo irá tomar, durante sua execução, configurando quais características são importantes durante o processo de busca.

\subsubsection{Avaliação dos autômatos adaptativos}

A avaliação dos autômatos adaptativo é realizada através da seguinte função de adequação:

adequação $=a+b \times(c+d+e \times(f+g+h+i))$.

sendo que:

$a=\frac{\text { quantidade de elementos computados }}{\text { quantidade de elementos na cadeia }} \times \alpha$.

$\mathrm{b}=\{\mathrm{n}: \mathrm{n}=1$ se o autômato computou toda a cadeia e $\mathrm{n}=0$ no caso contrário\}.

$c=\frac{\text { quantidade de transicoes utilizadas pelo automato }}{\text { quantidade de transicoes utilizadas no automato }} \times \beta$.
$d=\left(1-\frac{\text { quantidade de estados no automato inicialmente }}{\text { quantidade maxima de estados no automato inicialmente }}\right) \times \gamma$.

$\mathrm{e}=\{\mathrm{n}: \mathrm{n}=1$ se o autômato terminou o processamento em um estado de aceitação e $n=0$ no caso contrário\}.

$$
\begin{aligned}
& f=\left(1-\frac{\text { quantidade de transicoes inicialmente no automato }}{\text { quantidade maxima de transicoes inicialmente no automato }}\right) \times \delta \\
& g=\left(1-\frac{\text { quantidade de estados de aceitacao }}{\text { quantidade de estados do automato }}\right) \times \epsilon . \\
& h=\left(1-\frac{\text { quantidade de transicoes adaptativas no automato }}{\text { quantidade total de transicoes no automato }}\right) \times \zeta . \\
& i=\left(1-\frac{\left(\frac{\text { quantidade total de acoes adaptativas no automato }}{\text { quantidade de funcoes no automato }}\right)}{\text { quantidade maxima de acoes adaptativas por funcao }}\right) \times \eta .
\end{aligned}
$$

Os coeficientes $\alpha, \beta, \gamma, \delta, \epsilon \zeta$ e $\eta$ são pesos definidos na configuração do algoritmo.

Por exemplo, se o tamanho ou a eficiência do autômato é importante no resultado final, basta aumentar os coeficientes que multiplicam as relações que quantificam essas características. 


\subsubsection{Contra-exemplo}

Como observado anteriormente, a avaliação de soluções é uma atividade muito crítica no algoritmo. Ela é crítica porque a forma com que as soluções são avaliadas indica ao algoritmo para onde ele deve convergir.

Posto isso, foram observadas algumas ocorrências de os autômatos inferidos pelo algoritmo aceitarem não apenas a linguagem de interesse, mas um conjunto de cadeias maior que ela.

Com isso, ficou clara a necessidade da utilização de contra-exemplos no processo evolutivo dos autômatos, uma vez que, em algumas situações, não basta apenas saber o que aceitar, também é necessário saber o que não aceitar.

\subsubsection{Intercalando as formas de avaliação}

A introdução de contra-exemplos no algoritmo não foi trivial, pois foi necessária a tentativa de mais de uma abordagem para fazê-la. A abordagem inicial era a de intercalar a forma de avaliar as gerações: em uma geração os indivíduos eram avaliados com exemplos e na seguinte, seus descendentes eram avaliados com contra-exemplos. A forma de avaliar um indivíduo com contra-exemplo era oposta à forma de avaliá-lo com exemplo. Quanto mais rápido o autômato rejeitar um contra-exemplo, melhor era sua nota.

Os resultados obtidos com essa abordagem não foram bons: observou-se que o algoritmo deixava de convergir ao se aplicar essa técnica. O algoritmo não encontrava um autômato eficiente que reconhecia a linguagem de interesse e não reconhecia as cadeias apresentadas como contra-exemplo.

Acredita-se que as avaliações das gerações com contra-exemplo não forçavam a população de autômatos a convergir para o mesmo ponto que as avaliações com exemplos forçavam. Assim, algumas características de interesse que eram encontradas pelo algoritmo utilizando exemplos eram perdidas quando o algoritmo utilizava contra-exemplos, pois não havia garantias que os melhores indivíduos da população seriam mantidos na geração seguinte.

Procurando melhorar os resultados dessa abordagem, o algoritmo foi alterado para intercalar menos as formas de avaliação, de forma que passasse a realizar a avaliação com contra-exemplo na população uma vez a cada cinco, dez ou até mesmo vinte avaliações com exemplos positivos. Os resultados obtidos ainda foram os mesmos: o algoritmo não convergia. 


\subsubsection{Seleção artificial}

Para conseguir introduzir a utilização de contra-exemplos, foi necessário buscar um conceito de "seleção artificial", o mesmo praticado por fazendeiros com suas plantações e criações de animais. A idéia é remover características indesejadas da população, nesse caso, a capacidade de reconhecer cadeias que não pertencem à linguagem de interesse.

A abordagem adotada foi multiplicar a avaliação média dos indivíduos que reconheciam cadeias não pertencentes à linguagem por um fator de redução. O fator de redução possui valores entre 0 e 0,1. Assim, os indivíduos que reconhecem cadeias não pertencentes à linguagem ficam em franca desvantagem em relação aos demais indivíduos da população e tendem a ser eliminados nas seleções seguintes.

Uma vez removidos os indivíduos com características indesejadas, os indivíduos restantes ficam livres para competir entre si, buscando a melhor forma de aceitar a linguagem em questão.

Vale ressaltar que com linguagens mais simples, como as linguagens regulares, a ausência de contra-exemplos não é tão grave. A eficiência no autômato é buscada através de sua avaliação, que leva em consideração seu tamanho e a utilização de suas transições.

A necessidade do uso de contra-exemplos ficou evidente na inferência de linguagens livres de contexto. Os autômatos adaptativos, inferidos sem contraexemplos, tendiam a realizar aproximações de linguagens regulares semelhantes às linguagens livres de contexto que eles deveriam reconhecer. Por exemplo, eles tendiam a aceitar a linguagem $a^{n} b^{m}$ quando deveriam aceitar a linguagem $a^{n} b^{n}$.

Por último, é importante notar que para uma linguagem L, não é necessário utilizar todas as cadeias da linguagem $\bar{L}$, a linguagem formada por todas as cadeias não pertencentes a L, como contra-exemplo, uma vez que boa parte da otimização, realizada no autômato, é forçada pela própria função de avaliação do algoritmo.

Apenas alguns casos especiais, principalmente casos referentes à quantidade de repetições de elementos na cadeia, ficam de fora do processo de otimização e precisam ser complementados pela aplicação de contra-exemplos, como o caso da linguagem $a^{n} b^{n}$, descrita acima.

Com a utilização de contra-exemplos o funcionamento do algoritmo passou a ser como o descrito na figura 6.8. 


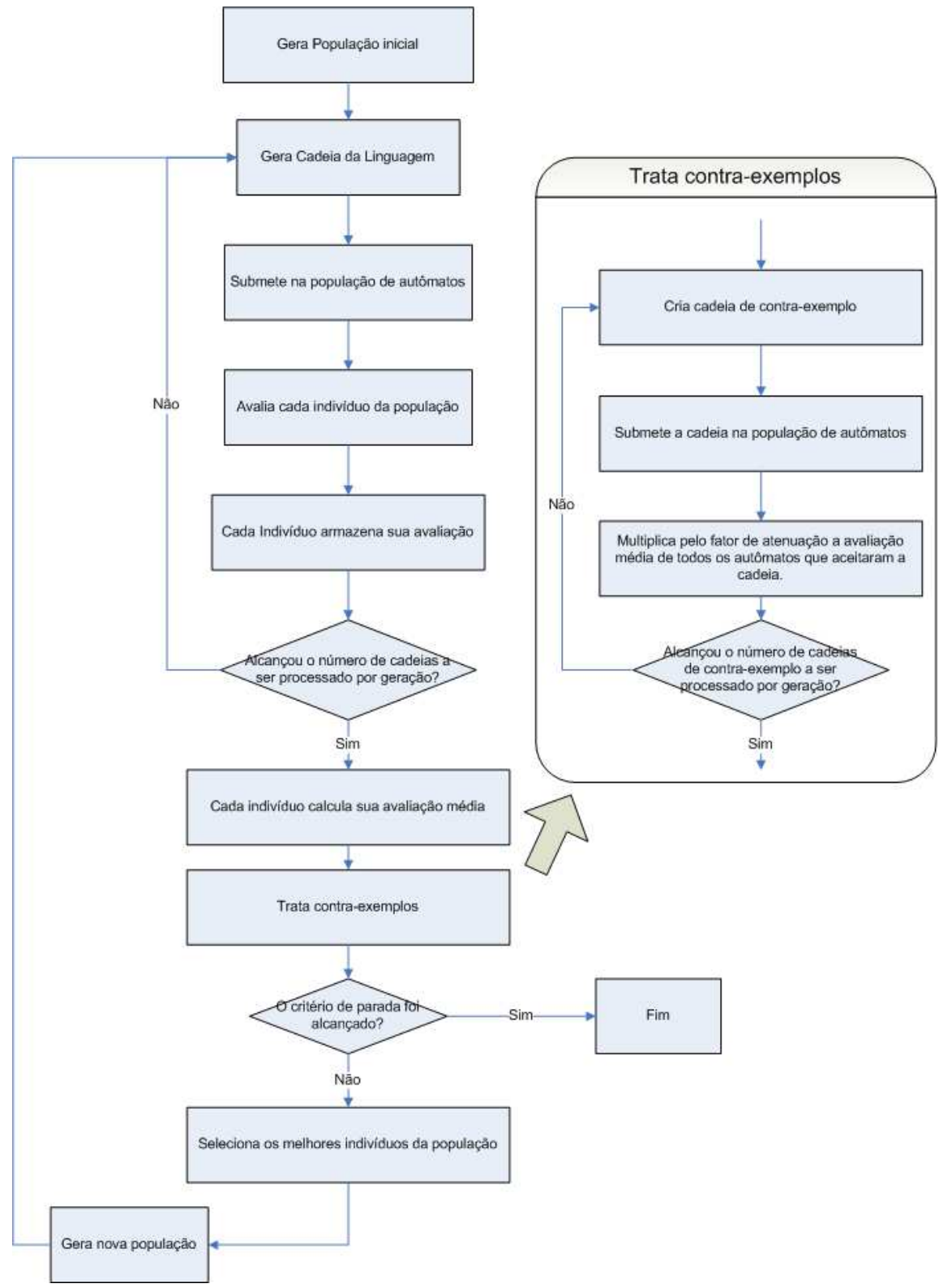

Figura 6.8: Funcionamento do algoritmo proposto com a utilização de contra-exemplo. 


\subsubsection{Relação de dominância dinâmica}

Como observado anteriormente, o objetivo da implementação de genomas diplóides é o de proteger algumas características genéticas contra seleções danosas. Há momentos em que é necessária mais de uma modificação simultânea no cromossomo de um indivíduo, para que sua avaliação seja superior às avaliações do restante da população. Assim, foi observado experimentalmente que qualquer alteração mais simples, com menos genes modificados, resulta em uma avaliação inferior.

Uma vez definidos dois genes para uma mesma posição, é necessário definir uma função R que, dados esses dois genes, retorne o valor dominante entre eles.

A definição de qual característica genética deve ser predominante não é trivial, pois não há uma regra clara de como decidir qual característica deve ser dominante. No caso desse estudo, as cadeias genéticas são codificadas sobre 0's e 1's, assim as funções de relação de dominância podem ser representadas pelos operadores lógicos AND, OR ou até mesmo XOR.

Conforme observado acima, a relação de dominância dinâmica busca uma relação de dominância entre os alelos que proteja novidades nos cromossomos. Assim, para uma determinada posição na cadeia de genes, o valor mais comum é o dominante, enquanto que a novidade introduzida por mutação, o valor menos comum, fica inativo até que ele seja combinado com outro gene de mesmo valor.

A relação de dominância é implementada da seguinte forma, para um cromossomo de comprimento n, ou seja, possuindo n genes em sua cadeia, é definido um vetor de funções de relação de dominância com n posições. Esse vetor é iniciado com funções implementadas pelo operador OR, ou seja, o valor 1 é dominante em relação ao 0 , em todas as posições do cromossomo.

A cada geração é realizado um censo, no qual é feito um levantamento para cada posição do cromossomo, entre todos os indivíduos da população. Se a quantidade de um dos valores, 0 ou 1, em uma determinada posição da cadeia, passar de p \% da quantidade total de indivíduos da população, a função de relação de dominância nessa posição é atualizada.

Se o valor predominante na população for 0 , em uma determinada posição da cadeia, então 0 será o valor dominante e a função de relação de dominância passará a ser implementada pelo operador AND, se o valor predominante for 1 , a função de relação de dominância será implementada pelo operador OR. 
Essa atualização no vetor de funções só ocorrerá se a quantidade de ocorrências de um dos valores, em uma determinada posição do cromossomo, passar de p \% da quantidade total de indivíduos da população, sendo que p é definido na configuração do algoritmo e o valor utilizado nos experimentos foi de $90 \%$.

Assim, espera-se que características que não predominam na população sejam recessivas, de forma que só serão visíveis no fenótipo dos indivíduos quando combinadas com genes do mesmo valor.

Conforme observado anteriormente, há momentos que uma mudança simples no fenótipo de um indivíduo é prejudicial para o mesmo, sendo necessário que ocorram outras mudanças simultâneas, para garantir que seu desempenho melhore em relação aos demais indivíduos da população.

É importante notar que o mecanismo diplóide não garante que as mudanças nos fenótipos ocorram sempre em conjunto, de forma benéfica para o indivíduo. Contudo, mesmo que dois genes recessivos se combinem e causem uma mudança simples no fenótipo do indivíduo, prejudicando sua avaliação, isso não fará com que esse gene seja eliminado da população, pois ele ainda pode existir de forma inativa em outros indivíduos.

Isso é verdadeiro porque, se dois genes recessivos foram combinados em um indivíduo, então há uma probabilidade muito alta de que pelo menos um deles tenha sido herdado, enquanto o outro pode ter surgido por mutação.

Dessa forma, ainda há chances de a característica definida pelo gene se combinar com outras características, em gerações futuras, e trazer vantagens de fato para os indivíduos.

Quando um conjunto desses genes recessivos passar a formar características vantajosas para os indivíduos, ocorrerá uma tendência de que esses genes se espalhem pela população, até que, em algum momento, eles se tornem dominantes.

\subsubsection{Operadores genéticos para soluções diplóides}

É importante notar que as operações genéticas, descritas em 5.4, são independentes da utilização de genomas haplóides ou diplóides. O operador genético, como o crossover ou a mutação, recebe um ou mais cromossomos e realiza a operação nesses cromossomos, independente do tipo de representação.

Por exemplo, na utilização de genomas haplóides, a recombinação genética de dois indivíduos A e B é feita através do crossover, recebendo diretamente o 


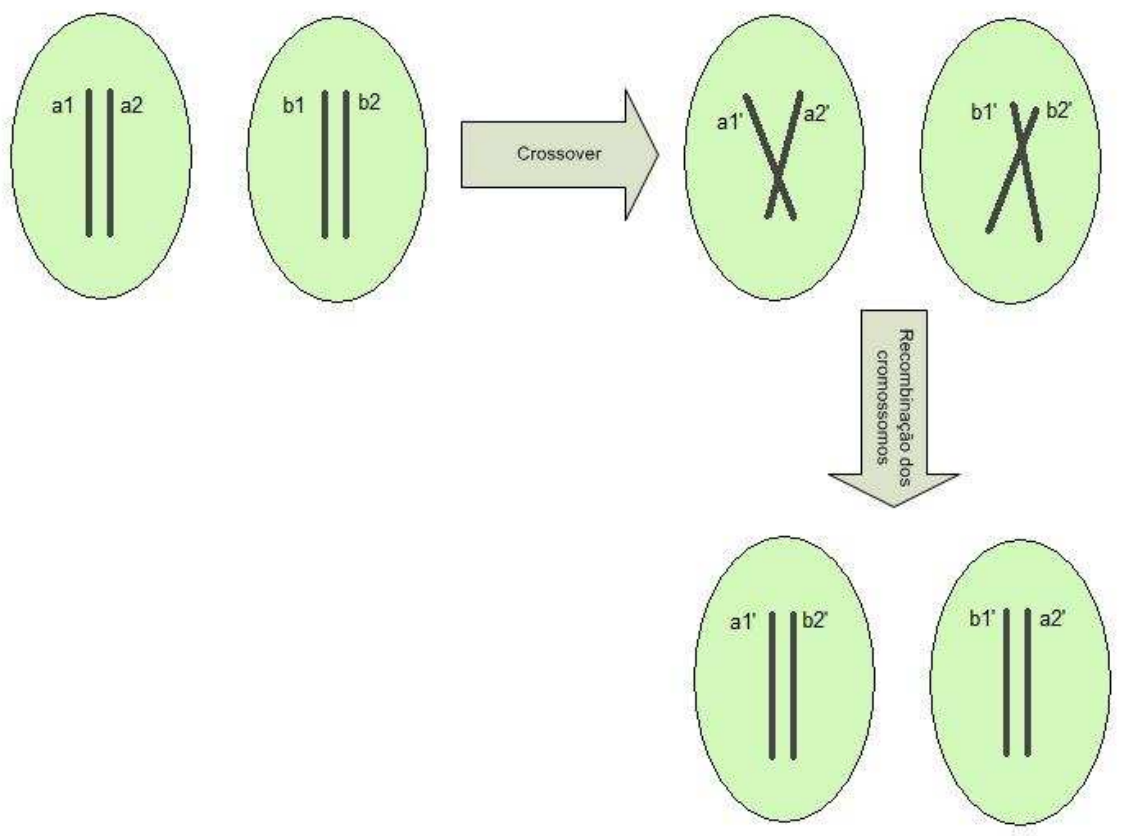

Figura 6.9: Crossover nos indivíduos diplóides.

cromossomo do indivíduo A e o cromossomo do indivíduo B, imitando de forma simplificada a recombinação biológica que ocorre entre dois indivíduos haplóides.

Baseado em (MITCHELL, 1996), a implementação realizada no presente trabalho, para a representação de genomas diplóides, o crossover ocorre antes da recombinação dos cromossomos dos diferentes indivíduos. Por exemplo, supondo que A e B sejam indivíduos diplóides, A com os cromossomos $a_{1}$ e $a_{2}$ e B com os cromossomos $b_{1}$ e $b_{2}$, antes de realizar a recombinação genética desses dois indivíduos, ocorrerá o crossover dos cromossomos $a_{1}$ com $a_{2}$ e $b_{1}$ com $b_{2}$, gerando os cromossomos $a_{1}$ ' e $a_{2}$ ' para o indivíduo A e os cromossomos $b_{1}$ ' e $b_{2}$ ' para o indivíduo B.

Só depois disso, que esses cromossomos serão rearranjados em pares,de forma aleatória, para gerar dois novos indivíduos, ambos com um cromossomo de A e um de B. Esse processo está representado na figura 6.9.

A mutação também ocorre da mesma forma, independente do tipo de genoma utilizado pelo algoritmo. Tanto no caso de representação diplóide quanto de haplóide cada cromossomo de cada indivíduo é submetido à operação de mutação, como descrita anteriormente. 


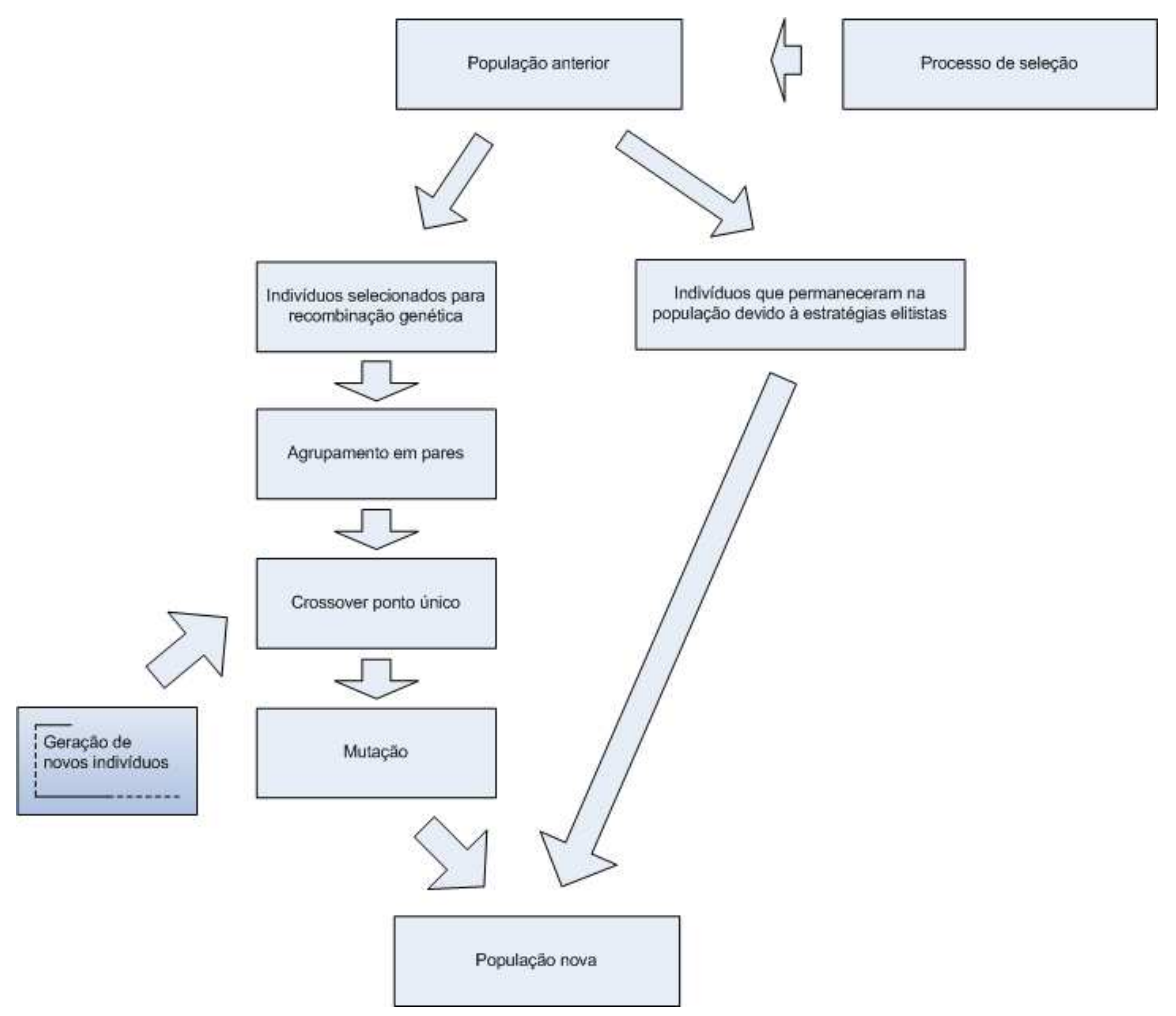

Figura 6.10: Fluxo dos operadores genéticos a que a população é submetida.

\subsubsection{Fluxo dos operadores genéticos}

As operações genéticas ocorrem no algoritmo da seguinte forma. Depois de avaliados, os indivíduos que permanecerão na população, devido a alguma estratégia elitista, serão copiados diretamente para a nova população.

Os indivíduos selecionados para recombinação genética, visando a formação de novos indivíduos, serão agrupados de dois em dois e nesses pares será aplicada a operação de crossover de ponto único.

Nesse processo serão criados dois novos indivíduos. Antes deles serem copiados para a nova população, cada um deles será submetido ao operador de mutação.

Depois disso, esses indivíduos são copiados, completando a nova geração de indivíduos. O fluxo de operações genéticas é ilustrado na figura 6.10.

Vale notar que essa seqüência de operadores independe do tipo de indivíduo. Por exemplo, no caso de coevolução, ambas as populações passam pela mesma seqüência.

Tratamentos extras, como a aplicação de contra-exemplos na seleção dos indivíduos, não trazem alterações nesse fluxo tampouco. Isso porque a aplicação de contra-exemplos ocorre durante o processo de avaliação. Esse processo se 
encontra em um passo anterior ao da geração de novas populações.

\subsubsection{Critério de parada}

Inicialmente, devido ao caráter exploratório dos experimentos realizados, foi decidido executar o algoritmo por tempo indeterminado, até que não houvesse mais uma evolução clara da população. A verificação da evolução da população se deu através da diferença entre a avaliação média dos n melhores indivíduos da população atual e a da população anterior.

A diferença entre as avaliações das populações deve ficar abaixo de um valor v por m gerações, para então ficar caracterizada uma estagnação na evolução.

Os valores de n, v e m fazem parte da configuração do algoritmo. Dependendo dos valores adotados, esse critério de parada pode nunca ser alcançado. Assim foi adotado também o critério any time, explicado em 5.9, para haver a opção de parar o algoritmo manualmente e obter a melhor solução calculada até o momento.

Contudo, durante os testes, foi verificado que, devido à geração aleatória das cadeias, as avaliações médias das populações variavam de geração para geração, mesmo sem haver mudanças nos indivíduos da população, de uma geração para outra. Assim, foi estabelecido um limite no número de gerações, para garantir que o algoritmo termine sua execução em tempo hábil. O limite foi definido em 500.000 gerações.

\subsection{Nova camada adaptativa}

A nova camada adaptativa consiste em um algoritmo genético que gera ações adaptativas para serem aplicadas no autômato da camada subjacente. A execução das ações adaptativas geradas visa a adequação do autômato para que o mesmo aceite a cadeia de entrada.

O funcionamento da camada adaptativa ocorre da seguinte maneira: quando acionada, ela submete uma população de autômatos finitos a um algoritmo genético que utiliza os caracteres recebidos da cadeia de entrada até o momento na avaliação de seus indivíduos.

O treinamento da população de autômatos ocorre da mesma maneira que foi proposta na inferência de autômatos finitos por algoritmos genéticos na seção anterior, com a principal diferença que não é possível o uso de algumas técnicas, como contra-exemplo e as cadeias de treinamento não são geradas aleatoriamente. 
A população de autômatos possui tamanho variável, a ser definido na configuração do algoritmo. Ela é iniciada com clones do autômato corrente da camada subjacente e seus indivíduos são submetidos ao algoritmo até que algum critério de parada seja alcançado.

O melhor indivíduo resultante da execução do algoritmo genético é selecionado e comparado com o autômato da camada subjacente. Os genomas de ambos os autômatos são submetidos a um processo que analisa as diferenças entre eles e, a partir dessas diferenças, extrai as ações adaptativas que são submetidas ao autômato da camada subjacente.

A execução das ações adaptativas resultante do processo de comparação entre o autômato calculado pelo algoritmo genético e o autômato corrente faz com que o autômato corrente se transforme em um autômato idêntico ao autômato calculado pela camada adaptativa.

Assim, do mesmo modo que a camada adaptativa tradicional cria uma nova máquina de estados a cada passo de sua execução, essa camada adaptativa, a partir de uma população de autômatos que evolui em função dos elementos de entrada recebidos até momento, substitui o autômato corrente pelo melhor autômato calculado, através de ações adaptativas geradas a partir das diferenças do autômato calculado e do autômato corrente da camada subjacente.

A cadeia utilizada no tratamento dos autômatos da camada adaptativa é constituída dos elementos recebidos até o momento da cadeia de entrada. Opcionalmente é possível implementar um lookahead, de maneira que a camada adaptativa sempre tenha computado n caracteres a mais que o autômato da camada subjacente. Assim, a camada adaptativa sempre consegue prever as alterações no autômato, antes que o mesmo rejeite a cadeia em questão.

Há algumas opções para o acionamento da camada adaptativa:

1. Ela pode ser acionada em todo passo de execução do autômato da camada subjacente;

2. Ela pode ser acionada sempre que o autômato da camada subjacente for rejeitar algum elemento da cadeia de entrada, ou

3. Ela pode ser acionada em p porcento de n passos de execução, sendo que n é o tamanho do buffer utilizado no lookahead, citado anteriormente, e p é uma porcentagem. Assim, para um lookahead de dez elementos, com p igual a cinqüenta, a camada adaptativa seria acionada de cinco em cinco 


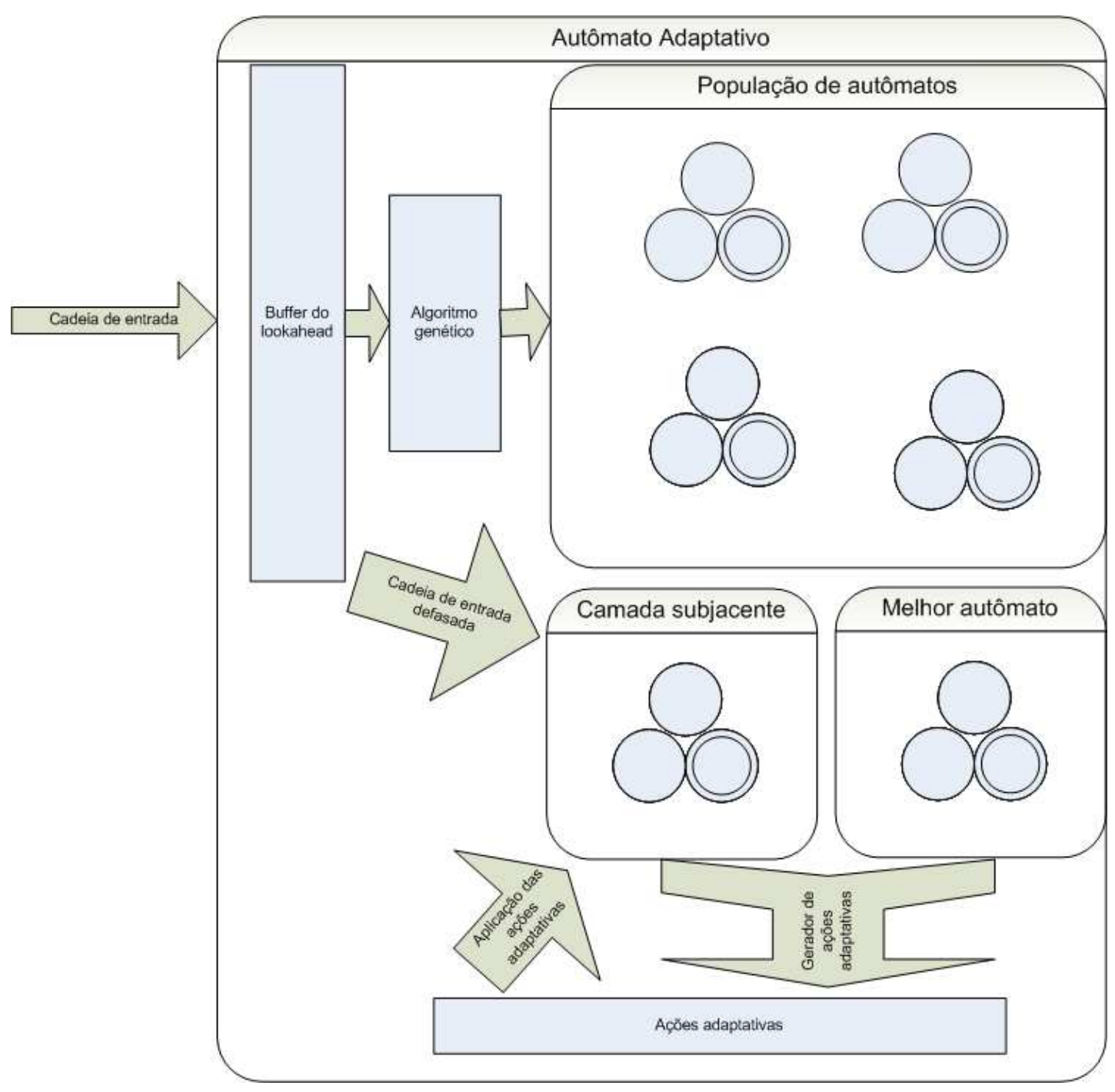

Figura 6.11: Nova camada adaptativa.

passos.

A figura figura 6.11 apresenta um esquema da proposta. 


\section{A implementação}

Uma vez definidas todas as características do algoritmo, esse capítulo descreve o processo utilizado na geração do software e as arquiteturas resultantes desse processo.

\subsection{O processo de software}

A implementação da solução foi feita em Java 6, utilizando-se do Eclipse Ganymede como ambiente de desenvolvimento. É possível obter mais informações sobre essas tecnologias nos endereços: http://java.sun.com e http://www.eclipse.org.

O desenho inicial da solução foi realizado através da técnica conhecida como cartões CRC ou Class-Responsibility-Collaboration cards, que é um método introduzido por Kent Beck em 1989 (BECK; CUNNINGHAM, 1989), através do qual é realizada a prospecção de módulos e a interação entre eles, dados os requisitos iniciais do sistema.

O requisito inicial do sistema é a implementação do algoritmo genético para realizar a inferência de autômatos finitos determinísticos e adaptativos. O funcionamento do algoritmo deve ocorrer da maneira descrita na seção 6.1, com todas as configurações previstas.

O processo empregado no desenvolvimento do software é o extreme programming, também conhecido como programação extrema ou simplesmente XP (BECK; ANDRES, 2004).

\subsubsection{Programação extrema}

Programação extrema se enquadra na classe de metodologias ágeis, para o desenvolvimento de software, como descrito em detalhes por Kent Beck em (BECK; ANDRES, 2004), ela é baseada em valores como comunicação, simplicidade, feedback, coragem, respeito, etc. 
Apesar de um dos pontos mais fortes dessa metodologia ser a comunicação entre os desenvolvedores e a transparência do processo para os clientes do projeto, este projeto foi desenvolvido, grande parte do tempo, de forma solitária, com poucas interações com outros personagens.

Por outro lado, essa metodologia possui alguns princípios extremamente úteis para a realização de um desenvolvimento com características fortemente exploratórias, como o projeto desenvolvido no presente trabalho, pois muitas das técnicas, como coevolução e genoma diplóide, não foram previstas nas primeiras versões do sistema. Os princípios mais utilizados foram:

Teste a princípio: Testes a princípio é uma técnica que permite a realização de testes em módulos básicos do sistema de forma automática, de maneira que cada alteração no software só está completa se todos os testes escritos anteriormente tiverem resultados positivos. Maiores informações sobre essa técnica podem ser obtidas em (BECK, 2002).

Durante a implementação dos algoritmos genéticos, vários módulos básicos foram testados por esse método, o que ajudou a diminuir muito o tempo de integração entre eles. Foram feitos testes sobre os operadores genéticos, a decodificação dos cromossomos e os métodos de seleção dos indivíduos, entre outros.

Devido à forte característica estocástica da implementação, foi necessária a criação de um módulo gerador de números aleatórios para encapsular a geração desses números e poder substituir sua implementação durante a execução dos testes, para que os resultados ocorram de forma controlada, facilitando a verificação do funcionamento unitário dos módulos.

Os testes automáticos dos módulos básicos facilitaram muito o desenvolvimento, pois, devido à grande complexidade do sistema, testar os módulos juntos com todo o restante do sistema dificultaria o processo de encontrar e corrigir erros.

Utilizar um módulo, sem garantir que ele funcione adequadamente, pode comprometer a utilização de uma técnica, pois como foram realizados experimentos com diversas técnicas diferentes, um erro na implementação de um módulo pode fazer com que o algoritmo não convirja para uma solução adequada e a técnica sendo testada seja injustamente descartada. 
Refatoração: consiste no processo de modificação de um software sem a alteração do seu funcionamento externo, sendo que essa alteração é realizada com o intuito de melhorar a estrutura interna do programa, tornando o código mais fácil de entender e facilitando futuras alterações no mesmo.

Para a utilização dessa técnica, é fundamental a utilização de testes a princípio, para garantir que a alteração no código não causou nenhum efeito colateral. Maiores informações sobre essa técnica pode ser consultada em (FOWLER, 1999).

Devido à característica exploratória do desenvolvimento do aplicativo, como mencionado anteriormente, o código fonte passou por várias alterações, para permitir que o sistema suportasse novas funcionalidades estudadas durante as pesquisas, realizadas em paralelo ao seu desenvolvimento.

Essas alterações acabam por prejudicar a qualidade do código como um todo. Assim, após cada mudança crítica no código, algumas sessões de refatoração eram realizadas, para trazer o código de volta a uma qualidade aceitável.

Mesmo antes de realizar uma alteração no sistema, por vezes eram necessárias algumas refatorações no código, para permitir que a alteração fosse realizada de forma mais elegante. Isso ocorre devido a algum erro ou descuido no desenho inicial que deveria ser corrigido antes de dar prosseguimento às alterações de interesse.

\subsection{Problemas encontrados}

Durante as iterações no desenvolvimento do sistema, foram encontradas algumas dificuldades, sendo as mais importantes:

"Contaminação" da lógica de autômatos nos módulos referentes ao algoritmo genético: Como observado anteriormente, a implementação do aplicativo foi realizada com caráter fortemente exploratório, sendo que a versão inicial previa apenas a inferência de um autômato finito determinístico, com uma representação haplóide, com método de seleção "roulettewheel" e com geração aleatória de cadeias. Ao implementar as características de coevolução, adicionando os indivíduos que representam as cadeias a serem processadas, observou-se que vários módulos, como ambiente, população, indivíduos, etc. estavam fortemente dependentes dos elementos envolvidos na representação dos autômatos. Esse acoplamento de lógica, do 
autômato com o algoritmo genético, ocorreu de forma inconsciente durante o desenvolvimento do sistema. O desacoplamento exigiu uma quantidade considerável de horas refatorando o código, para viabilizar o prosseguimento das pesquisas.

"Contaminação" da lógica haplóide nos módulos referentes ao algoritmo genético: A mesma dificuldade relatada anteriormente ocorreu com a representação genética dos indivíduos. A implementação de vários módulos estava baseada no fato do genoma ser haplóide, foram necessárias várias refatorações nos módulos responsáveis pela criação e recombinação de genes para realizar a implementação de genomas diplóides.

Teste a princípio: Os próprios módulos que realizavam testes unitários automatizados estavam baseados em alguns princípios, como o fato de todos os indivíduos serem autômatos finitos e os genomas serem haplóides, ou seja, apesar de trazerem mais segurança na integração dos diversos módulos desenvolvidos, os testes a princípio geram códigos maiores para sofrer manutenção com o passar do tempo. Além disso, testes relativamente simples possuíam módulos de testes bastante complexos, gerando a necessidade de vários objetos de apoio, como os objetos mock. Esses objetos apenas imitam objetos reais para facilitar a implementação dos testes.

\subsection{Implementação dos Autômatos}

A implementação dos autômatos adaptativos teve como base o que foi apresentado em (NETO, 1993) e (NETO, 2001). Ela foi realizada levando em consideração o requisito dos autômatos poderem ser definidos dinamicamente, ou seja, que eles fossem definidos durante a execução do sistema.

Essa condição se deve ao fato dos autômatos serem gerados a partir das seqüências genéticas obtidas durante a execução do algoritmo genético. Assim, não é possível prever em código todas as configurações.

A implementação do autômato finito determinístico se deu através da arquitetura representada na figura figura 7.1.

O autômato é representado pelo objeto Automato. Ele mantém o controle do estado atual, do estado inicial e de quais estados são de aceitação. Ao receber um elemento, ele despacha para o estado atual, representado pelo módulo Estado, para verificar se há uma transição disponível para aquele elemento. Em caso 


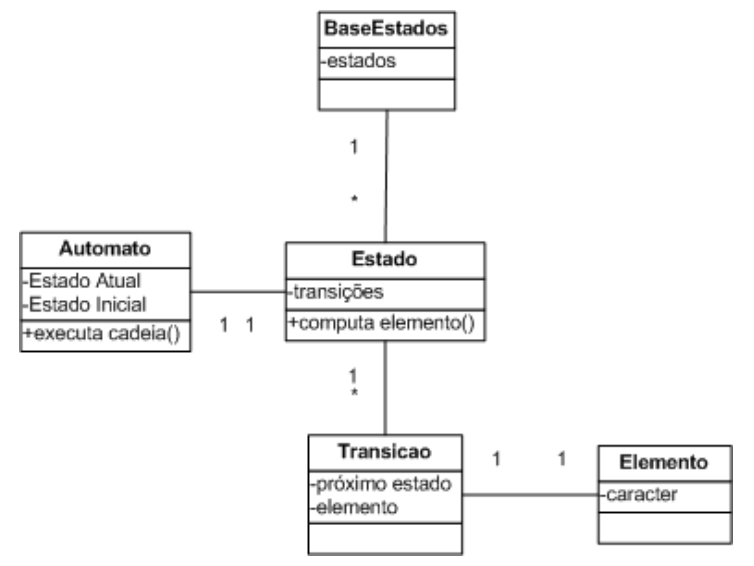

Figura 7.1: Arquitetura básica da implementação do autômato finito.

afirmativo, é retornado um novo estado atual para o autômato, como resultado do processamento do elemento.

O módulo BaseEstados é uma tabela de símbolos que auxilia na montagem do autômato, ele mantém a referência de todos os objetos Estado, evitando que haja duas instâncias dessa classe representando o mesmo estado.

No caso do autômato adaptativo, é introduzida a camada adaptativa ao modelo descrito. Para isso, a camada adaptativa foi simplificada e implementada através da introdução de duas chamadas opcionais a funções adaptativas, sendo uma a função adaptativa pré-transição, executada antes da realização da transição e a outra a função adaptativa pós-transição, executada depois da realização da transição.

A função adaptativa é composta por uma lista de parâmetros, uma lista de geradores, uma lista de variáveis e uma lista de ações adaptativas elementares, que são as ações de inserção, remoção e consulta. Como restrição a função adaptativa, foi decidido que não seria possível fazer referência direta a um estado do autômato, ou seja, para que um estado seja referenciado, ele deve ser passado como parâmetro ou ser atribuído através das ações de consulta ou remoção.

A fim de simplificar a implementação, também ficou decidido que os únicos valores que podem ser representados por variáveis, nas funções adaptativas, são os estados, ou seja, elementos e funções devem ser referenciados diretamente. Apesar de não poderem ser referenciados através de variáveis, os valores dos elementos e das funções são considerados durante a pesquisa por transições, na execução das ações de consulta e remoção. A arquitetura básica da implementação do autômato adaptativo é apresentada na figura 7.2.

A implementação do autômato adaptativo é praticamente a mesma utilizada 


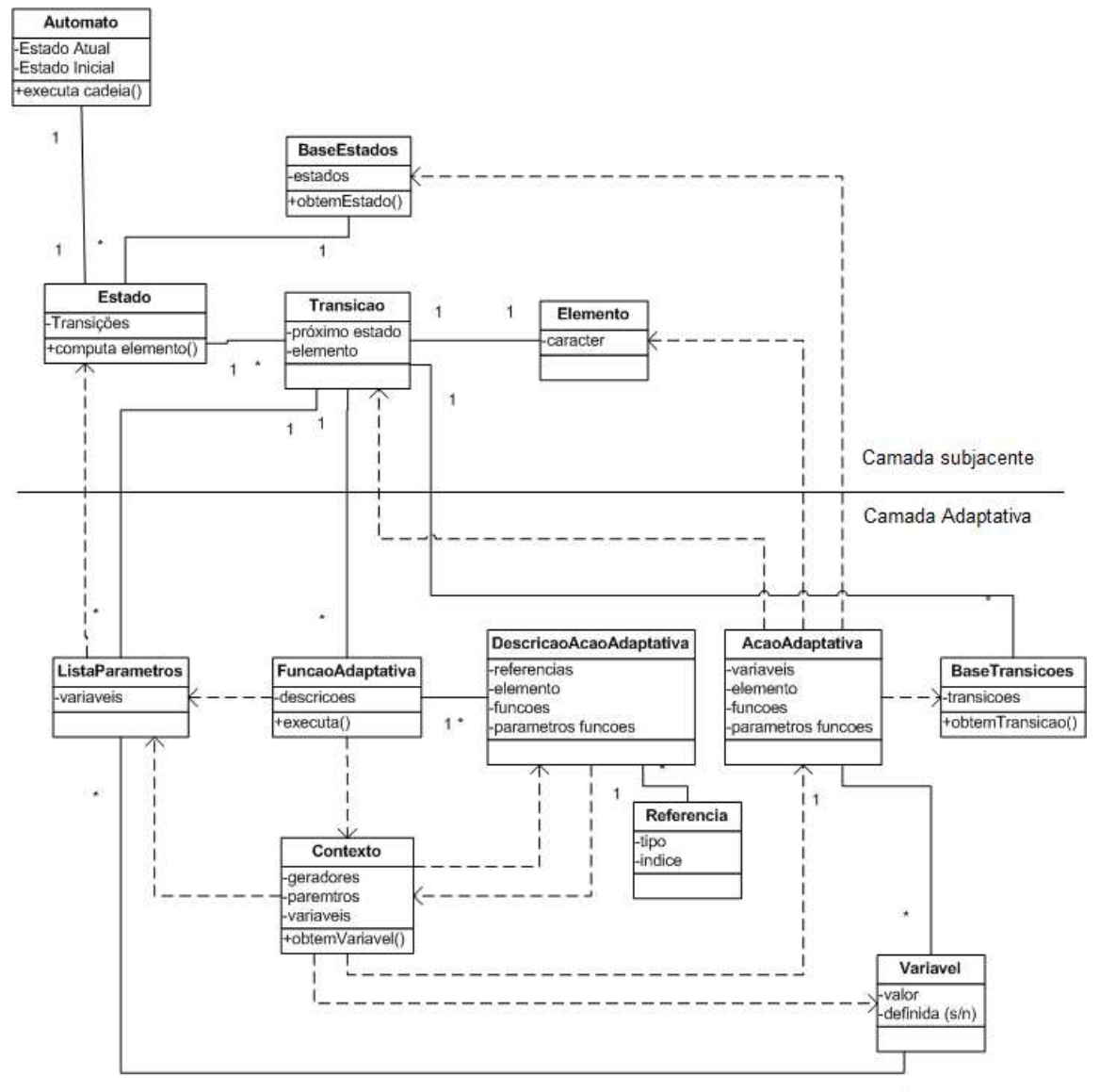

Figura 7.2: Arquitetura básica da implementação do autômato adaptativo. 
na implementação do autômato finito. Foram adicionados módulos que implementam a camada adaptativa do autômato. O principal elemento adicionado ao autômato foi a FuncaoAdaptativa. Esse elemento é opcionalmente associado a todas as transições, de forma que durante a execução, no momento em que uma determinada transição for acionada, ela irá executar as funções adaptativas associadas a ela.

Diferentemente do que se imagina, a função adaptativa não é composta por uma lista de ações adaptativas, mas sim por uma lista de descritores de ações adaptativas. Isso ocorre porque a ação adaptativa só pode ser totalmente definida durante a execução da função, pois as variáveis só podem ser definidas a partir do contexto de execução da função. O descritor de uma ação adaptativa não possui variáveis, mas sim referências, que são compostas por um tipo e um índice. O tipo indica a classe da variável que está sendo referenciada na ação, ou seja, se é uma variável simples, um parâmetro ou um gerador. O índice identifica a variável dentro de sua classe.

Ao iniciar a execução de uma função adaptativa, é passada uma lista de parâmetros, representado pelo módulo ListaParametros, para a função e a partir desse objeto é criado um contexto de execução, representado pelo módulo Contexto. Nesse contexto os geradores são criados e iniciados com valores únicos, as variáveis são criadas e todos, juntamente com os parâmetros recebidos, são armazenados para serem referenciados durante a execução da função.

Durante a execução, as ações adaptativas que compõem a função são criadas a partir de seus descritores e da lista de variáveis que compõem o contexto de execução.

Da mesma forma que foi criado o módulo BaseEstados para facilitar a busca de estados pelo autômato, foi criado o módulo BaseTransicoes, que indexa todas as transições que compõem o autômato, a fim de tornar a busca por transições durante a execução das ações de consulta e remoção mais simples.

O objeto FuncaoAdaptativa possui um comando denominado "compila". Esse comando deve ser executado antes da execução da função adaptativa, ele tem o papel de organizar os descritores das ações adaptativas, de maneira a garantir que a execução das ações respeite a ordem que dá prioridade para as ações de consulta, depois às de remoção e por último às de inserção.

Por último, ao implementar a função adaptativa inicial, foi prevista a possibilidade de uma transição ser removida durante a execução de sua própria 


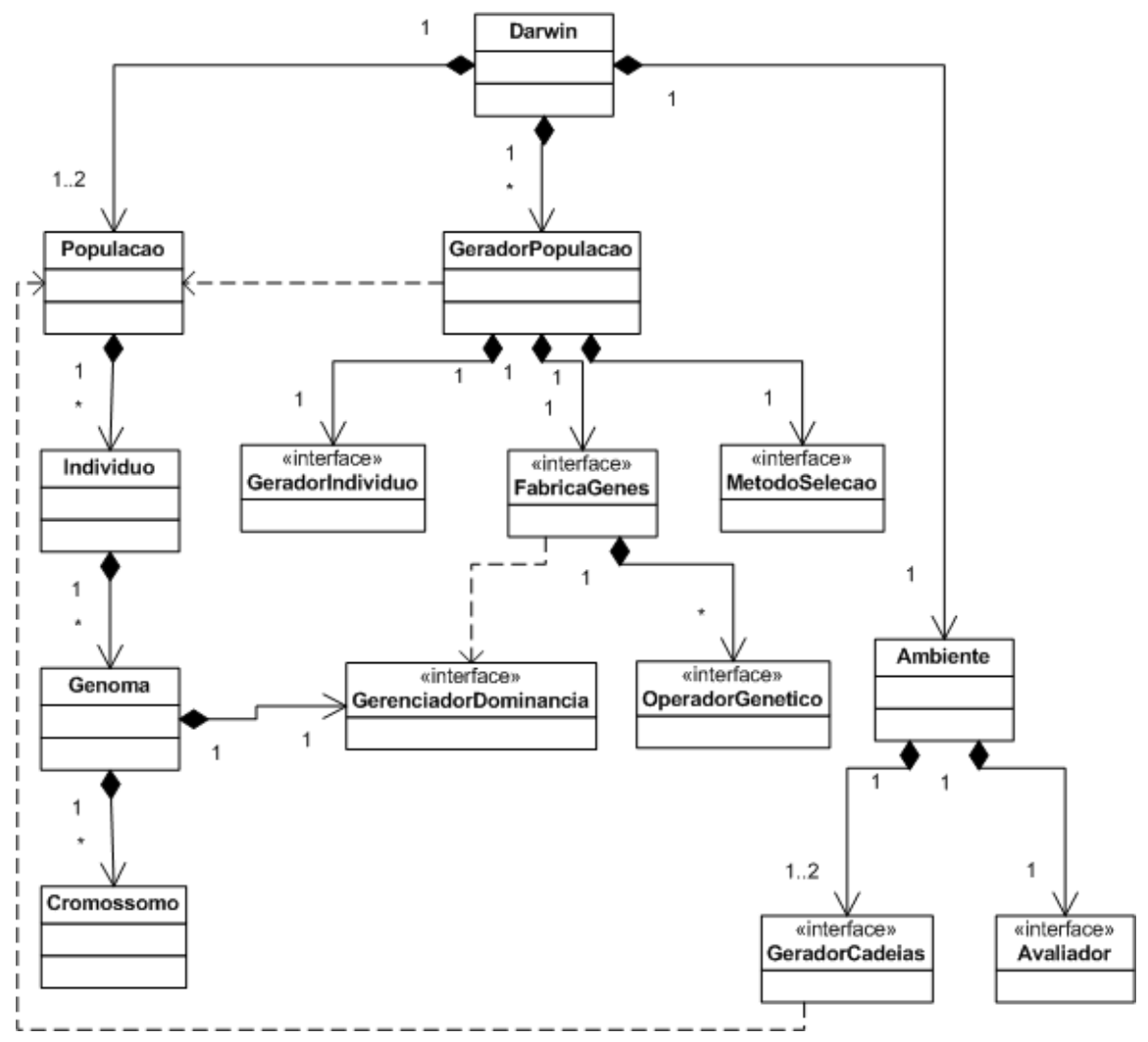

Figura 7.3: Arquitetura final da implementação do algoritmo.

função adaptativa inicial. Essa questão foi resolvida adicionando-se um atributo às transições, que indica se ela foi removida ou não. Assim, ao final da execução da função adaptativa inicial, esse atributo é verificado e se a transição tiver sido removida, o autômato não a realiza, computando novamente o elemento recebido, conforme proposto em (NETO, 1993).

\subsection{Arquitetura da solução - Darwin}

A arquitetura final da solução, denominada Darwin, consiste nos módulos representados no diagrama da figura 7.3.

O módulo principal do sistema é o Darwin. Nesse módulo são definidas algumas configurações básicas do algoritmo, como o tipo de representação genética dos indivíduos e os tipos de avaliação e seleção realizadas.

Esse módulo consiste em três outros módulos, o Ambiente, o GeradorPopulacao e o Populacao.

O Ambiente é responsável por realizar a avaliação da população. Nesse módulo a população de autômatos é submetida a cadeias, que são geradas pelo módulo GeradorCadeias, e o desempenho de cada autômato é medido através 
do módulo Avaliador. Os módulos GeradorCadeias e Avaliador são representados como interfaces, pois as classes que os implementam são definidas em tempo de execução, de acordo com a configuração do ambiente e com a linguagem a ser inferida.

A geração das cadeias pertencentes à linguagem é feita de forma aleatória ou por uma população de indivíduos, através de expressões regulares ou mesmo gramáticas, dependendo da implementação do módulo GeradorCadeias.

No caso de ambiente com coevolução, o módulo GeradorCadeias possui uma dependência do módulo Populacao, pois as cadeias são geradas através da população de cadeias, que possue o papel de parasita no algoritmo.

Com a utilização de contra-exemplos, o ambiente pode ter dois geradores de cadeias, um para exemplos positivos e outro para negativos.

O módulo GeradorPopulacao é o responsável pela criação e reprodução dos indivíduos da população em estudo. Ele possui três sub-módulos, que são: GeradorIndividuo, FabricaGenes e MetodoSelecao.

O GeradorIndividuos é responsável por criar instâncias de novos indivíduos na população, dado um genoma que o defina.

O módulo FabricaGenes é responsável pela criação e recombinação dos genomas da população. Dado um ou mais genomas. Esse módulo aplica operações genéticas como crossover e mutação para recombiná-los para a geração de novos indivíduos na população. Vale notar que esse módulo também possui uma dependência do módulo GerenciadorDominancia, essa dependência será explicada mais adiante.

O módulo MetodoSelecao é responsável por selecionar indivíduos a partir dos quais a nova geração será criada, esses indivíduos seriam os antepassados diretos de alguns dos novos indivíduos presentes na próxima geração. Esse módulo também seleciona alguns indivíduos para simplesmente permanecer na próxima geração, realizando a implementação da estratégia elitista.

Por último, o módulo Populacao é uma composição de todos os indivíduos, ou seja, qualquer operação realizada sobre a população será realizada sobre cada indivíduo através desse módulo. Cada indivíduo é representado através do módulo Individuo.

No algoritmo proposto há basicamente dois tipos de indivíduo, o autômato e a cadeia. Como observado anteriormente, esse segundo tipo de indivíduo é 
utilizado no caso da configuração com coevolução. A implementação de cada indivíduo será discutida mais adiante, na seção 7.4.1.

Cada indivíduo possui um genoma, representado pelo módulo Genoma, que é o módulo responsável por gerenciar suas características genéticas, seu genótipo, constituído de um ou mais cromossomos. O cromossomo é representado pelo módulo Cromossomo, e sua multiplicidade varia de 1 para n, com o módulo Genoma, dependendo se o indivíduo for diplóide ou haplóide.

O fenótipo do indivíduo é decodificado a partir de seu genoma. No caso de representação haplóide, a decodificação é realizada de forma direta. Para indivíduos diplóides, a decodificação ocorre com o auxílio do módulo GerenciadorDominancia, módulo responsável por definir a relação de dominância entres os alelos correspondentes.

Na implementação do módulo GerenciadorDominancia, o algoritmo precisa realizar um censo na população, antes de definir a relação de dominância entres os alelos. Para isso, existe a dependência desse módulo com o módulo FabricaGenes, mencionado anteriormente. Assim, no momento que os genes dos novos indivíduos estão sendo criados, através das operações genéticas, é realizado o censo contabilizando a predominância de cada alelo na população.

\subsubsection{Implementação do indivíduo e decodificação genética}

O processo de decodificação genética realizado pelo algoritmo foi implementado através da arquitetura representada na figura 7.4 para o indivíduo do tipo autômato.

O módulo Individuo é uma classe abstrata, sendo deixados alguns detalhes a serem definidos, dependendo do tipo de indivíduo que ele representa, se ele representa um autômato ou uma cadeia, por exemplo.

O módulo IndividuoAutomato é uma extensão do módulo Individuo, ele possui um módulo MontadorAutomato que, dado um GenomaAutomato (que também é uma extensão do módulo Genoma), monta o autômato representado pelo indivíduo.

O módulo GenomaAutomato também implementa a interface DescritorAutomato, que define alguns métodos para facilitar a obtenção do fenótipo do indivíduo pelo MontadorAutomato.

Essa mesma arquitetura se aplica a indivíduos representando uma cadeia 


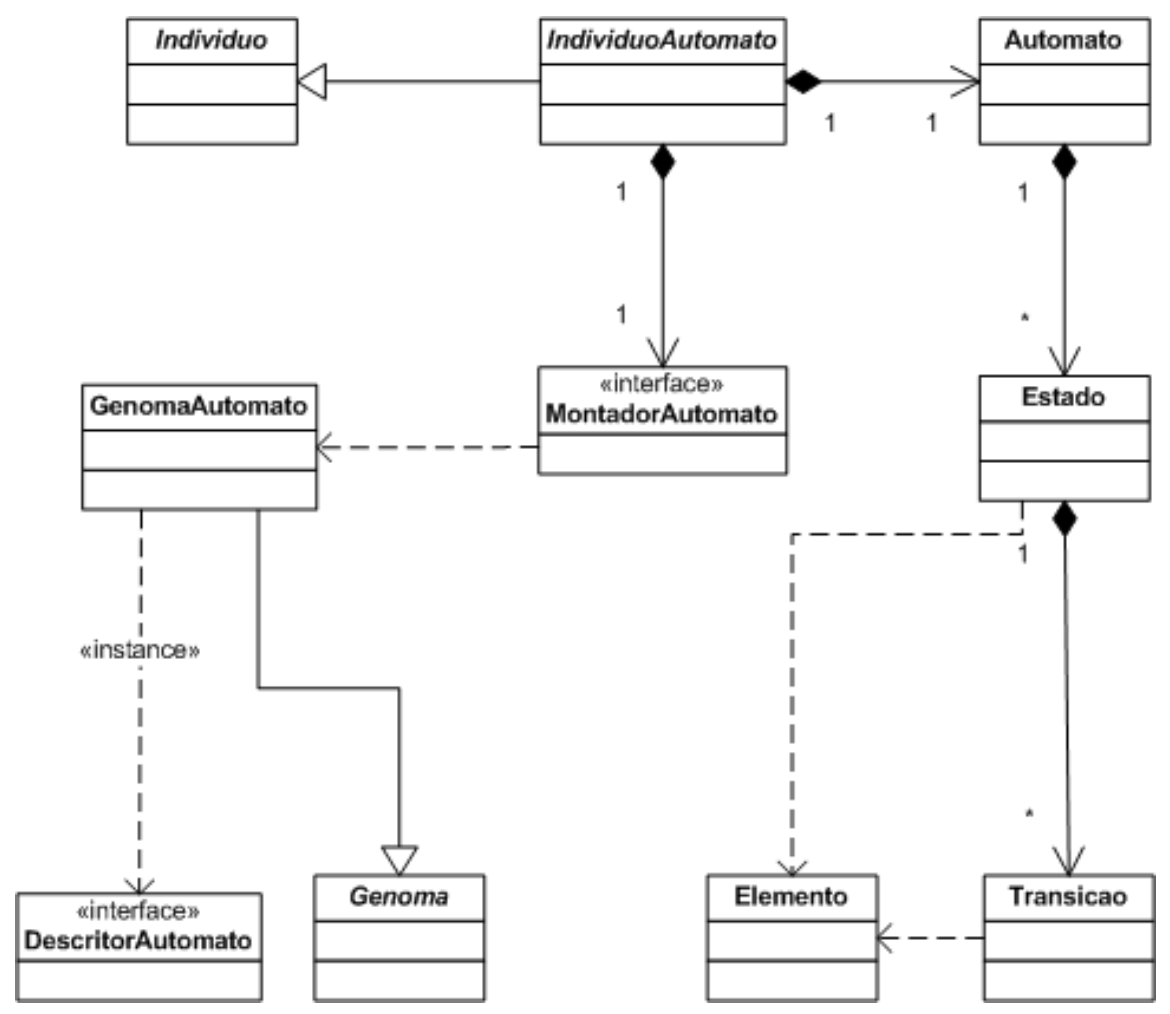

Figura 7.4: Arquitetura do indivíduo do tipo autômato.

de uma linguagem, como pode ser visto na figura 7.5, sendo que as principais diferenças ocorrem nas classes que estendem os módulos Individuo e Genoma.

No caso da utilização de coevolução, o ambiente é alterado para tratar duas populações, uma de autômatos e a outra de cadeias. Nesse caso, a implementação do módulo GeradorCadeias passará a depender da população de cadeias. 


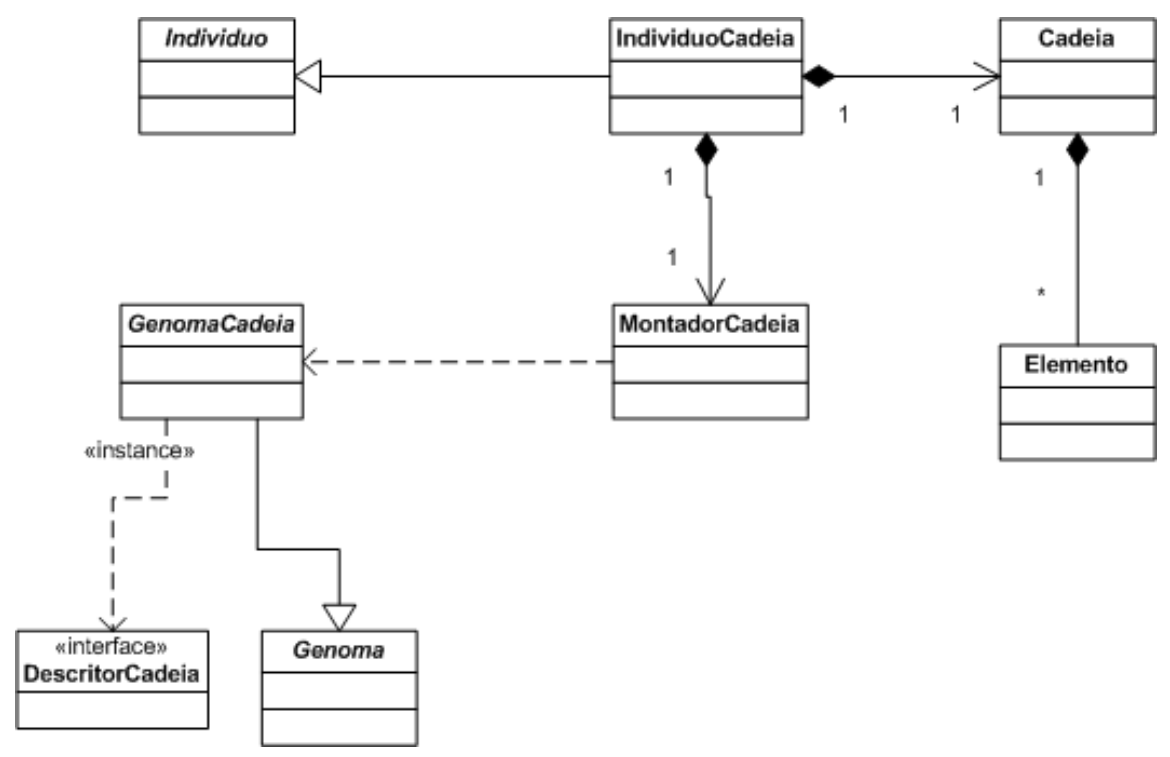

Figura 7.5: Arquitetura do indivíduo do tipo cadeia. 
Parte IV

\section{Ensaios e Conclusões}


Nessa parte são apresentados alguns resultados práticos, alcançados através da execução do aplicativo implementado durante as pesquisas realizadas nesse trabalho. Os testes realizados não visam esgotar todas as possíveis configurações do aplicativo, apenas apresentar a qualidade de alguns dos resultados obtidos e como algumas das técnicas utilizadas influenciaram na qualidade desses resultados. 


\section{Ensaios}

Os testes apresentados neste capítulo têm o intuito de calibrar o algoritmo genético proposto nos capítulos anteriores desse trabalho e expor os resultados obtidos com a aplicação das técnicas propostas.

\subsection{Calibração do algoritmo}

A calibração do algoritmo foi realizada primeiramente para o autômato finito, pois se trata de um dispositivo mais simples que o autômato adaptativo.

A idéia é usar a calibração do autômato finito, como configuração inicial para os testes de inferência do autômato adaptativo.

Inicialmente foi realizada a micro-calibração do algoritmo. Para isso, foi utilizada uma configuração básica, que consiste em indivíduos haplóides, com o método de seleção roulette wheel e uma população de autômatos finitos.

Em alguns gráficos e tabelas, foram exibidos os valores da função de avaliação como uma forma de comparar os indivíduos encontrados pelo algoritmo. Esses valores não possuem, isoladamente, um valor prático. Porém, utilizando-os como meio de comparação, é possível observar qual das soluções encontradas foi a mais apta, tendo como base os conceitos considerados pela função de avaliação.

\subsection{Tratamento dos dados}

Os resultados apresentados nesse capítulo foram obtidos da seguinte forma: cada medida foi realizada 5 vezes, dos resultados obtidos, o melhor e o pior são descartados e a média dos 3 resultados restantes é apresentada. 


\subsection{Casos de teste}

Baseado na literatura (FREGNI, 1997), há basicamente dois caminhos: realizar ensaios sobre conjuntos de linguagens geradas aleatoriamente ou eleger um conjunto específico de linguagens que sirva como base para a análise. Nesse trabalho, foi eleito um grupo específico de linguagens.

\subsubsection{Linguagens utilizadas}

Durante os testes, foram utilizadas as seguintes linguagens:

$\boldsymbol{a} \boldsymbol{b}^{*}$ - Uma linguagem regular bastante simples. A idéia de realizar testes com essa linguagem consiste em verificar o funcionamento do algoritmo para uma tarefa trivial.

$\boldsymbol{a}^{*} \boldsymbol{b} \boldsymbol{c}^{*} \boldsymbol{d}$ - Trata-se de uma linguagem um pouco mais complexa que a anterior. O objetivo dessa linguagem é verificar o funcionamento do algoritmo com linguagens formadas por um vocabulário com mais elementos.

$a b^{n}$, com n sendo um inteiro múltiplo de $\mathbf{5}$ - Trata-se de uma linguagem simples, porém com a característica de apresentar um número de caracteres 'b' múltiplo de 5. Com essa linguagem, foi testada a utilização de contraexemplos na inferência de autômatos finitos.

$\boldsymbol{a}^{n} \boldsymbol{b}^{n}, \operatorname{com} \boldsymbol{n} \geq \mathbf{1}$ - Essa linguagem é livre de contexto. Ela foi utilizada nos testes da inferência do autômato adaptativo.

\subsection{Calibração do algoritmo para autômatos fi- nitos}

Inicialmente foi realizada a calibração dos parâmetros do algoritmo, utilizando a inferência de autômatos finitos.

Nesse primeiro momento dos testes, os índices $\alpha, \beta, \gamma \delta e \epsilon$ foram todos iniciados com o valor 1.0 para que nenhuma característica prevaleça sobre as demais. Para as taxas de mutação e crossover, foram adotados os valores considerados comuns pela literatura (EBERHART; SHI; KENNEDY, 2001). 


\subsubsection{Taxa de sobrevivência}

O primeiro parâmetro a ser calibrado é a taxa de sobrevivência, para isso será utilizada a configuração exposta na tabela 8.1. Os valores experimentados da taxa de sobrevivência foram $0 \%, 10 \%, 30 \%$ e $50 \%$.

Tabela 8.1: Configuração para a calibração da taxa de sobrevivência

\begin{tabular}{|c|c|}
\hline \hline Configuração & Valor \\
\hline População & 80 \\
\hline Método de seleção & roulette wheel \\
\hline$\alpha, \beta, \gamma \delta e \epsilon$ & $1.0,1.0,1.0,1.0$ e 1.0 \\
\hline Taxa de normalização & não utilizado \\
\hline Quantidade de cadeias por geração & 5 \\
\hline Tipo genoma & haplóide \\
\hline Coevolução & não utilizado \\
\hline Taxa crossover & $90 \%$ \\
\hline Taxa mutação & $1 \%$ \\
\hline Contra-exemplo & não utilizado \\
\hline Linguagem utilizada & ab* \\
\hline Quantidade máxima de gerações & 250.000 \\
\hline \hline
\end{tabular}

Os resultados obtidos estão apresentados na figura 8.1, como é possível observar, utilizar o roulette wheel sem estratégia elitista não traz bons resultados.

O motivo disso pode ser observado no gráfico da figura 8.2. Nesse gráfico é apresentada a avaliação do melhor indivíduo encontrado até o momento e o melhor indivíduo da geração atual, para as taxas de sobrevivência $0 \%$ e $10 \%$.

Assim, sem estratégia elitista o melhor indivíduo da população atual é sempre inferior ao melhor indivíduo encontrado até o momento. Isso ocorre porque sem a estratégia elitista o algoritmo não possui a memória dos melhores resultados encontrados até o momento, pois a chance de qualquer indivíduo permanecer nas gerações seguintes é bastante baixa, pois seu genoma será recombinado com algum outro indivíduo.

Por outro lado, com a taxa de sobrevivência de $10 \%$, é possível observar no gráfico que as curvas do melhor indivíduo da geração atual e do melhor indivíduo encontrado até o momento são praticamente as mesmas, mostrando que o melhor indivíduo encontrado até o momento sempre está presente nas gerações futuras. 


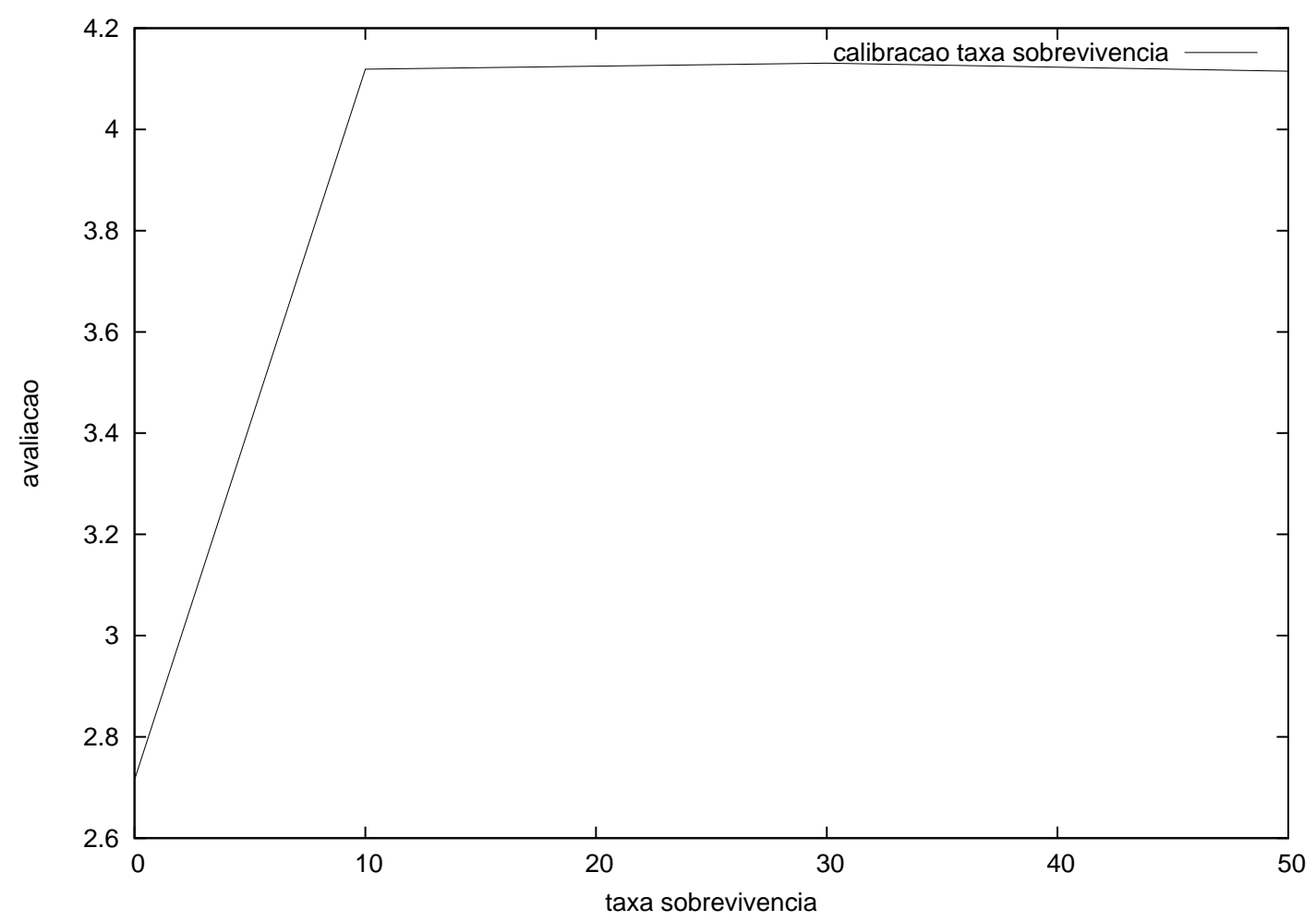

Figura 8.1: Calibração da taxa de sobrevivência.

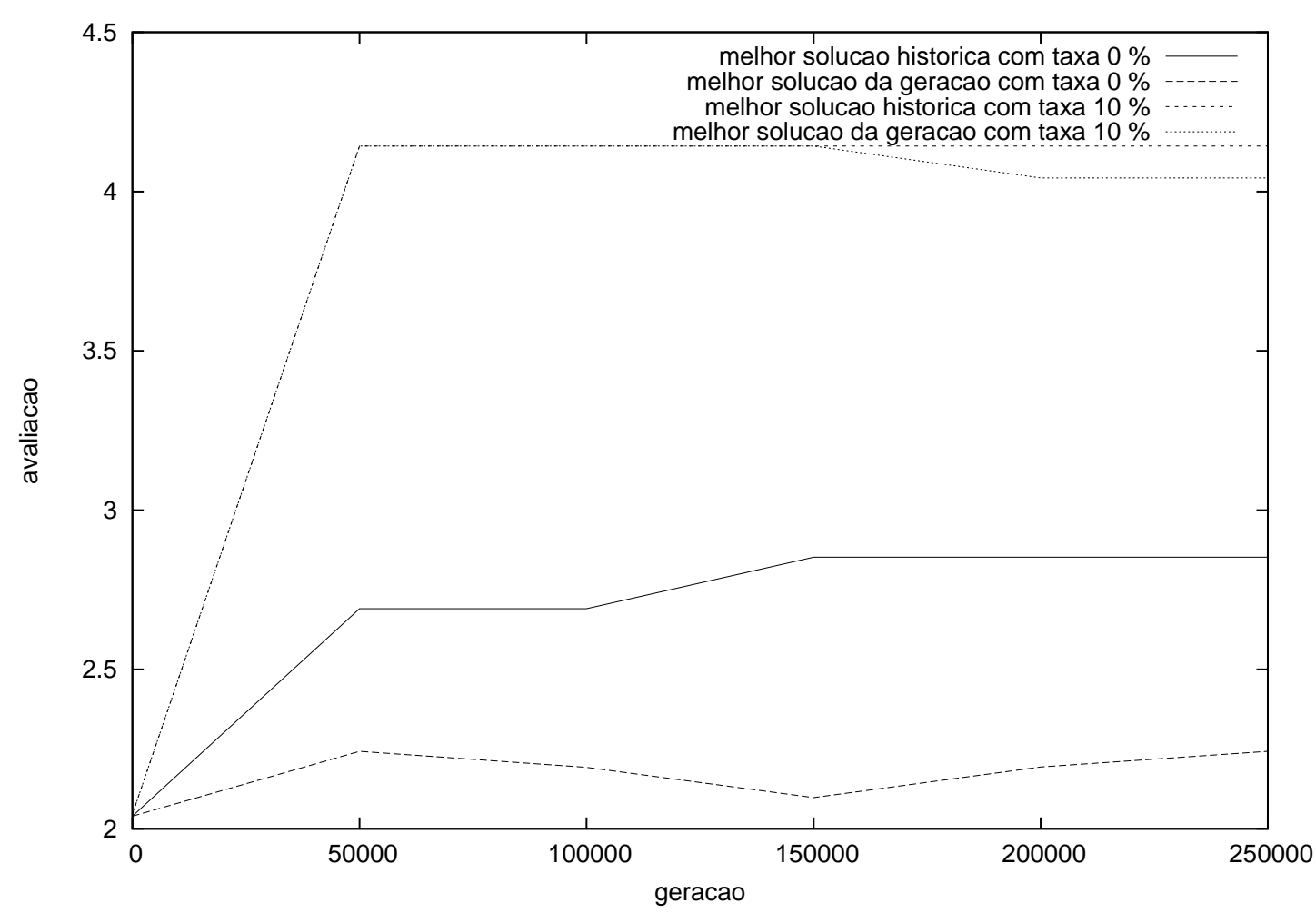

Figura 8.2: Evolução do algoritmo com diferentes taxas de sobrevivência. 


\subsubsection{Taxa de normalização}

Conforme discutido na seção 5.7.1.1, a taxa de normalização é uma variação do método roulette wheel. Os valores experimentados foram $0 \%, 10 \%, 30 \%, 50 \%$, $70 \%$ e $90 \%$. A configuração do teste está na tabela 8.2.

Tabela 8.2: Configuração para a calibração da taxa de normalização

\begin{tabular}{|c|c|}
\hline \hline Configuração & Valor \\
\hline População & 80 \\
\hline Método de seleção & roulette wheel \\
\hline$\alpha, \beta, \gamma \delta$ e $\epsilon$ & $1.0,1.0,1.0,1.0$ e 1.0 \\
\hline Taxa de sobrevivência & $0 \%$ e $10 \%$ \\
\hline Quantidade de cadeias por geração & 5 \\
\hline Tipo genoma & haplóide \\
\hline Coevolução & não utilizado \\
\hline Taxa crossover & $90 \%$ \\
\hline Taxa mutação & $1 \%$ \\
\hline Contra-exemplo & não utilizado \\
\hline linguagem utilizada & a*bc ${ }^{*} \mathrm{~d}$ \\
\hline \hline Quantidade máxima de gerações & 250.000 \\
\hline \hline
\end{tabular}

Como pode ser observado na figura 8.3, a taxa de normalização exerce influência maior em algoritmos sem elitismo. Com $10 \%$ de taxa de sobrevivência, não é possível verificar mudanças claras na qualidade das soluções obtidas.

\subsubsection{Tamanho população}

A calibração do tamanho da população foi realizada através da configuração descrita na tabela 8.3. Os valores experimentados foram 20, 40, 60, 80, 100, 120 e 140 indivíduos. Os resultados podem ser observados no gráfico apresentado na figura 8.4. Nota-se que o melhor resultado obtido foi com a população de 100 indivíduos. Contudo, os valores obtidos com a população de 100, 120 e 140 indivíduos são muito próximos, dentro do intervalo do desvio padrão. Portanto, pode-se dizer que populações maiores que 100 não trazem vantagens claras para o algoritmo, nessa configuração.

\subsubsection{Genoma diplóide}

O teste realizado com o genoma diplóide se enquadra no conceito de macrocalibração, com isso, a avaliação do autômato obtido foi comparada com o autômato obtido com a mesma configuração, exceto pela codificação genética. A configuração do teste está descrita na tabela 8.4. 


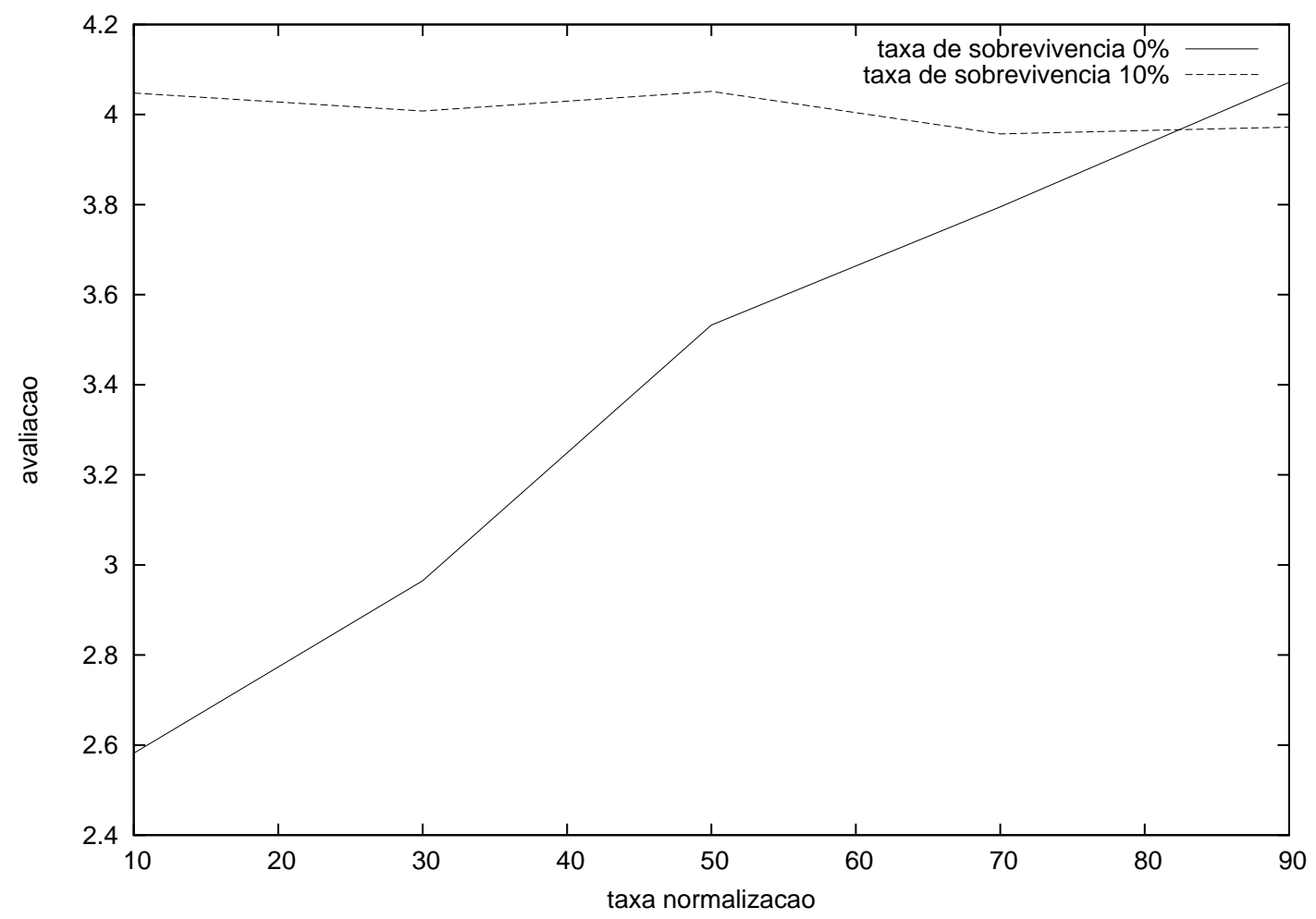

Figura 8.3: Calibração da taxa de normalização.

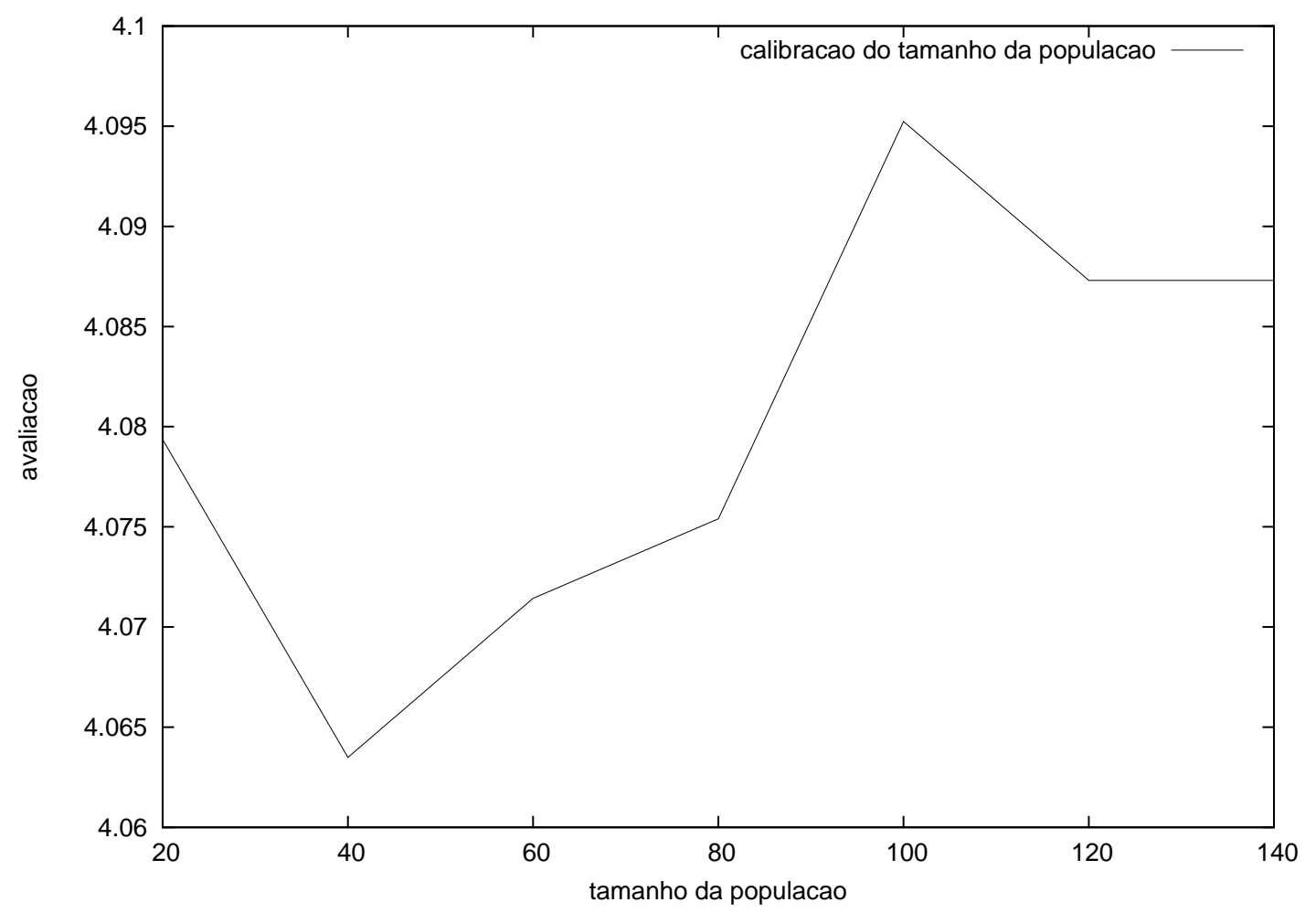

Figura 8.4: Calibração do tamanho da população. 
Tabela 8.3: Configuração para a calibração do tamanho da população

\begin{tabular}{|c|c|}
\hline \hline Configuração & Valor \\
\hline Método de seleção & roulette wheel \\
\hline$\alpha, \beta, \gamma \delta e \epsilon$ & $1.0,1.0,1.0,1.0$ e 1.0 \\
\hline Taxa de sobrevivência & $10 \%$ \\
\hline Quantidade de cadeias por geração & 5 \\
\hline Tipo genoma & haplóide \\
\hline Coevolução & $90 \%$ \\
\hline Taxa crossover & $1 \%$ \\
\hline Taxa mutação & não utilizado \\
\hline Taxa de normalização & não utilizado \\
\hline Contra-exemplo & $a^{*}$ bc*d \\
\hline linguagem utilizada & 250.000 \\
\hline \hline
\end{tabular}

Tabela 8.4: Configuração do algoritmo com genoma diplóide

\begin{tabular}{|c|c|}
\hline \hline Configuração & Valor \\
\hline População & 80 \\
\hline Método de seleção & roulette wheel \\
\hline$\alpha, \beta, \gamma \delta e \epsilon$ & $1.0,1.0,1.0,1.0$ e 1.0 \\
\hline Taxa de sobrevivência & $10 \%$ \\
\hline Quantidade de cadeias por geração & 5 \\
\hline Tipo genoma & haplóide e diplóide \\
\hline Coevolução & não utilizado \\
\hline Taxa crossover & $90 \%$ \\
\hline Taxa mutação & $1 \%$ \\
\hline Taxa de normalização & não utilizado \\
\hline Contra-exemplo & não utilizado \\
\hline linguagem utilizada & ab* \\
\hline Quantidade máxima de gerações & 250.000 \\
\hline \hline
\end{tabular}

Como é possível observar na tabela 8.5, foram obtidos resultados superiores com a codificação diplóide. O desvio do resultado da configuração diplóide foi 0.0 porque as cinco medidas realizadas obtiveram o mesmo valor. Esse valor corresponde ao autômato apresentado na figura 8.5. Esse autômato é o mais eficiente para a linguagem.

\subsubsection{Coevolução}

O algoritmo, com o ambiente apresentando coevolução, foi executado com a configuração apresentada na tabela 8.6. Os resultados obtidos foram comparados com o ambiente executado sem a utilização de coevolução.

O resultado obtido, apresentado na tabela 8.7, foi o mesmo resultado obtido 
Tabela 8.5: Comparação dos resultados obtidos com os genomas haplóide e diplóide

\begin{tabular}{|c|c|c|}
\hline \hline Genoma & Avaliação & Desvio \\
\hline Haplóide & 4.12 & \pm 0.02 \\
\hline Diplóide & 4.14 & \pm 0.0 \\
\hline \hline
\end{tabular}

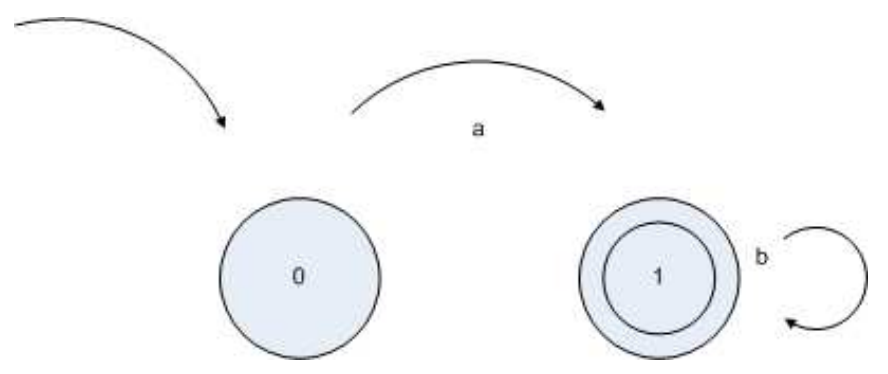

Figura 8.5: Autômato calculado pelo algoritmo genético com genoma diplóide.

com o genoma diplóide. Isso ocorreu porque as duas técnicas foram implementadas com o objetivo de otimizar os resultados obtidos com o algoritmo genético tradicional. Assim, o autômato alcançado para a linguagem em questão era o mais eficiente possível e foi o mesmo encontrado pelo algoritmo com a codificação genética diplóide, representado na figura 8.5.

\subsubsection{Contra-exemplo}

O teste realizado com a utilização de contra-exemplos, para a inferência de autômatos finitos, da mesma forma como ocorreu nas seções anteriores, se enquadra na macro-calibração. Portanto, o resultado obtido será comparado com o resultado obtido da inferência da mesma linguagem, sem a utilização de contraexemplos.

A configuração utilizada para realizar o teste está descrita na tabela 8.8.

Conforme ocorreu nos testes anteriores, os resultados obtidos sem estratégia elitista foram inferiores aos resultados obtidos com a taxa de sobrevivência em $10 \%$.

Porém, apenas analisar os números obtidos pode levar a conclusões erradas. Uma nota maior, conforme exposto na seção 6.1.7.1, indica um autômato mais simples. Sem o contra-exemplo, o autômato obtido é igual ao autômato obtido com a utilização do genoma diplóide, apresentado na figura 8.5. Esse autômato aceita a linguagem $a b^{*}$, não apenas a linguagem $a b^{n}$, com n múltiplo de 5, ou seja, o autômato encontrado pelo algoritmo, sem contra-exemplos, está incorreto. 
Tabela 8.6: Configuração do algoritmo utilizando coevolução

\begin{tabular}{|c|c|}
\hline \hline Configuração & Valor \\
\hline População & 80 \\
\hline Método de seleção & roulette wheel \\
\hline$\alpha, \beta, \gamma \delta e \epsilon$ & $1.0,1.0,1.0,1.0$ e 1.0 \\
\hline Taxa de sobrevivência & $10 \%$ \\
\hline Quantidade de cadeias por geração & 5 \\
\hline Tipo genoma & haplóide \\
\hline Coevolução & utilizado \\
\hline Taxa crossover & $90 \%$ \\
\hline Taxa mutação & $1 \%$ \\
\hline Taxa de normalização & não utilizado \\
\hline Contra-exemplo & não utilizado \\
\hline linguagem utilizada & ab* \\
\hline Quantidade máxima de gerações & 250.000 \\
\hline \hline
\end{tabular}

Tabela 8.7: Comparação dos resultados obtidos utilizando coevolução

\begin{tabular}{|c|c|c|}
\hline \hline Genoma & Avaliação & Desvio \\
\hline Sem coevolução & 4.12 & \pm 0.02 \\
\hline Com coevolução & 4.14 & \pm 0.0 \\
\hline \hline
\end{tabular}

Um dos autômatos calculados com a utilização de contra-exemplo está apresentado na figura 8.6. Apesar desse autômato aceitar cadeias não pertencentes à linguagem, ele é muito mais restrito do que o calculado sem contra-exemplos.

A linguagem utilizada como contra-exemplo foi $a b^{n}$, com n não múltiplo de 5.

\subsubsection{Conclusões parciais}

No início das pesquisas, ao realizar os primeiros testes de inferência dos autômatos finitos, foi observado que o algoritmo conseguia apresentar soluções, que aceitava a linguagem alvo, com uma rapidez muito grande.

Ao analisar os resultados, observou-se que isso ocorria porque os autômatos encontrados aceitavam na verdade qualquer linguagem e possuíam praticamente todas as transições e estados possíveis ativos.

Com isso, houve uma grande preocupação em otimizar os resultados obtidos, através das diversas técnicas utilizadas na inferência dos autômatos finitos.

O que foi possível observar através dos experimentos realizados é que a utilização dessas técnicas foi muito bem sucedida. Inicialmente algumas podem ter deixado a desejar, como foi o caso da utilização de contra-exemplos, contudo, 
Tabela 8.8: Configuração do algoritmo com a utilização de contra-exemplo

\begin{tabular}{|c|c|}
\hline \hline Configuração & Valor \\
\hline População & 80 \\
\hline Método de seleção & roulette wheel \\
\hline$\alpha, \beta, \gamma \delta e \epsilon$ & $1.0,1.0,1.0,1.0$ e 1.0 \\
\hline Taxa de sobrevivência & $0 \%$ e $10 \%$ \\
\hline Quantidade de cadeias por geração & 5 \\
\hline Tipo genoma & haplóide \\
\hline Coevolução & não utilizado \\
\hline Taxa crossover & $1 \%$ \\
\hline Taxa mutação & não utilizado \\
\hline Taxa de normalização & $a b^{n}$, com n múltiplo de 5 \\
\hline linguagem utilizada & 250.000 \\
\hline \hline
\end{tabular}

Tabela 8.9: Comparação dos resultados obtidos com e sem a utilização de contra-exemplos

\begin{tabular}{|c|c|c|c|}
\hline \hline Algoritmo & taxa sobrevivência & Avaliação & Desvio \\
\hline com contra-exemplo & $0 \%$ & 2.87 & \pm 0.03 \\
\hline sem contra-exemplo & $0 \%$ & 2.75 & \pm 0.03 \\
\hline com contra-exemplo & $10 \%$ & 3.77 & \pm 0.08 \\
\hline sem contra-exemplo & $10 \%$ & 4.14 & \pm 0.0 \\
\hline \hline
\end{tabular}

todas acabaram ficando bastante refinadas na tarefa de otimizar as soluções encontradas.

\subsection{Autômato Adaptativo}

Foram utilizadas as mesmas configurações calibradas com o autômato finito. Essa configuração foi definida principalmente pela semelhança entre o autômato adaptativo e o autômato finito. Apesar de não haver garantias de que uma configuração boa para o autômato finito seja boa para o autômato adaptativo, a configuração será utilizada como ponto de partida nos testes.

Os índices $\alpha, \beta, \gamma, \delta, \epsilon \zeta e \eta$ foram iniciados com os valores 10.0, 2.0, 3.0, 5.0, 5.0, 10.0 e 5.0, respectivamente. Esses valores foram obtidos através de testes com a linguagem regular ab*, utilizando a codificação genética de autômatos adaptativos. Foi observado que esses índices proporcionam autômatos adaptativos mais eficiêntes do que quando se utiliza todos os índices com o valor 1.0.

Para a taxa de crossover, foi adotado o valor considerado comum pela literatura (EBERHART; SHI; KENNEDY, 2001), para a taxa de mutação, foi utilizado 


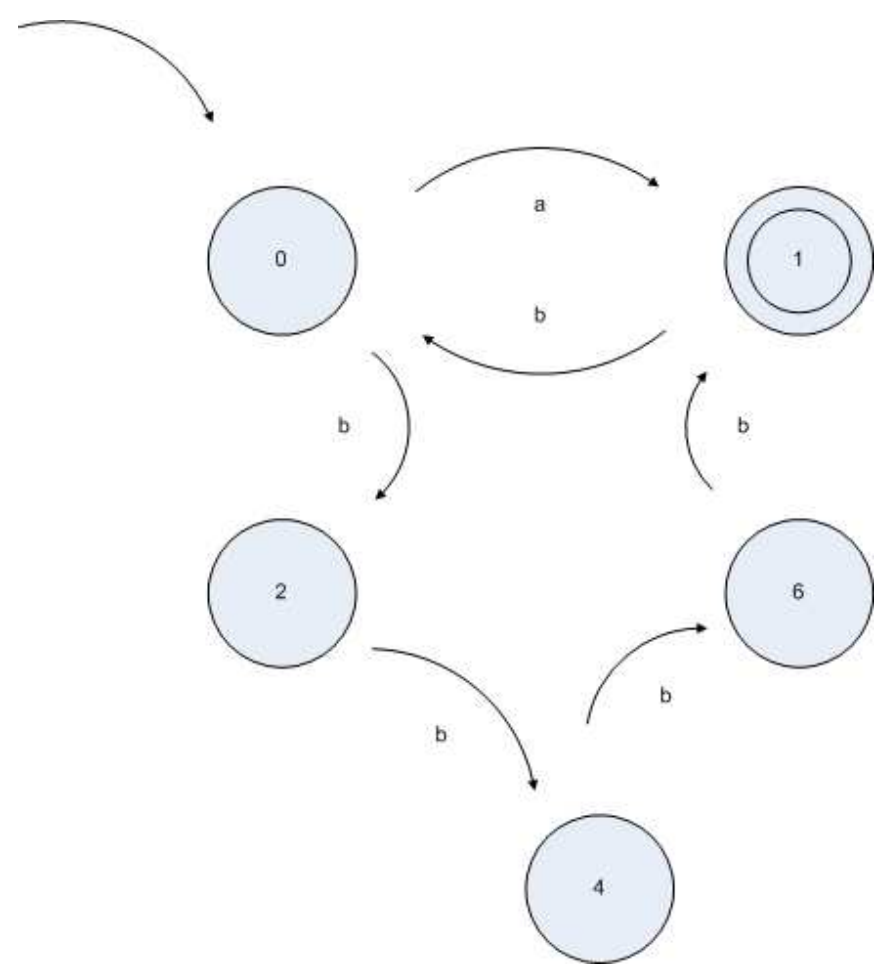

Figura 8.6: Autômato calculado pelo algoritmo genético utilizando contra-exemplos.

uma valor mais alto que o indicado pela literatura, pois acredita-se que utilizando a taxa de sobrevivência maior que $0 \%$, os bons resultados obtidos não serão perdidos com a mutação.

A configuração considerada para os testes está definida na tabela 8.10.

Os resultados obtidos podem ser observados na tabela 8.11. Para cada configuração utilizada seguem considerações sobre o resultado obtido:

Autômato adaptativo : A inferência dos autômatos adaptativos, conforme descrito na seção 6.1.2, não foi bem sucedida. Não foi possível fazer o algoritmo apresentar um autômato adaptativo que fizesse sentido para a linguagem utilizada.

Um fator que diferencia esse caso do caso da inferência de autômatos finitos foi a utilização de contra-exemplos. Devido à semelhança de linguagem a ser inferida com a linguagem $a^{*} b^{*}$, foi necessária a utilização de contraexemplo, pois no caso contrário, as características do autômato adaptativo, utilizadas na inferência de uma linguagem com aninhamento sintático, nunca seriam forçadas pelo processo de evolução. A linguagem utilizada como contra-exemplo era $a^{n} b^{m}$, com $n \neq m$. Assim, o indivíduo que aceitasse $a^{*} b^{*}$ era retirado da população, pois sua nota era zerada antes do 
Tabela 8.10: Configuração do algoritmo na inferência de autômatos adaptativos

\begin{tabular}{|c|c|}
\hline \hline Configuração & Valor \\
\hline População & 100 \\
\hline Método de seleção & roulette wheel \\
\hline$\alpha, \beta, \gamma, \delta, \epsilon \zeta$ e & $10 \%$ \\
\hline Taxa de sobrevivência & 5 \\
\hline Quantidade de cadeias por geração & haplóide e diplóide \\
\hline Tipo genoma & não utilizado \\
\hline Coevolução & $90 \%$ \\
\hline Taxa crossover & $10 \%$ \\
\hline Taxa mutação & não utilizado 5.0 \\
\hline Taxa de normalização & utilizado \\
\hline Contra-exemplo & $a^{n} b^{n}$ \\
\hline linguagem utilizada & 250.000 \\
\hline Quantidade máxima de gerações & $2.0,5.0,10.0$ e \\
\hline \hline
\end{tabular}

Tabela 8.11: Comparação dos resultados obtidos na inferência dos autômatos adaptativos

\begin{tabular}{|c|c|c|}
\hline \hline Autômato adaptativo & Avaliação & aceita a linguagem \\
\hline Autômato adaptativo & 34.841466 & não \\
\hline Autômato sem parâmetros na função adaptativa & 34.554338 & não \\
\hline Autômato sem parâmetros diplóide & 34.784506 & não \\
\hline Autômato fixo & 34.333844 & sim \\
\hline \hline
\end{tabular}

processo de seleção.

Acredita-se que o baixo desempenho obtido foi devido à grande complexidade apresentada pelo dispositivo a ser inferido. Uma combinação de genes bastante específica era necessária para que o autômato passasse a aceitar a linguagem.

Além disso, não foi possível estabelecer um caminho evolutivo bem determinado para que o algoritmo percorresse. Em outras palavras, o fitness landscape não possuía um gradiente claro da função de avaliação que apontasse para a solução desejada. Assim, o algoritmo realizava mutações e combinações genéticas aleatoriamente, na tentativa de "esbarrar" em um resultado útil.

Autômato sem parâmetros na função adaptativa : Na tentativa de obter melhores resultados, procurou-se simplificar o modelo a ser inferido. Um elemento que aumentava muito a complexidade do modelo era a lista de parâmetros, passada na invocação da função adaptativa.

Apesar dos esforços, não foi possível encontrar um autômato que aceitasse a 


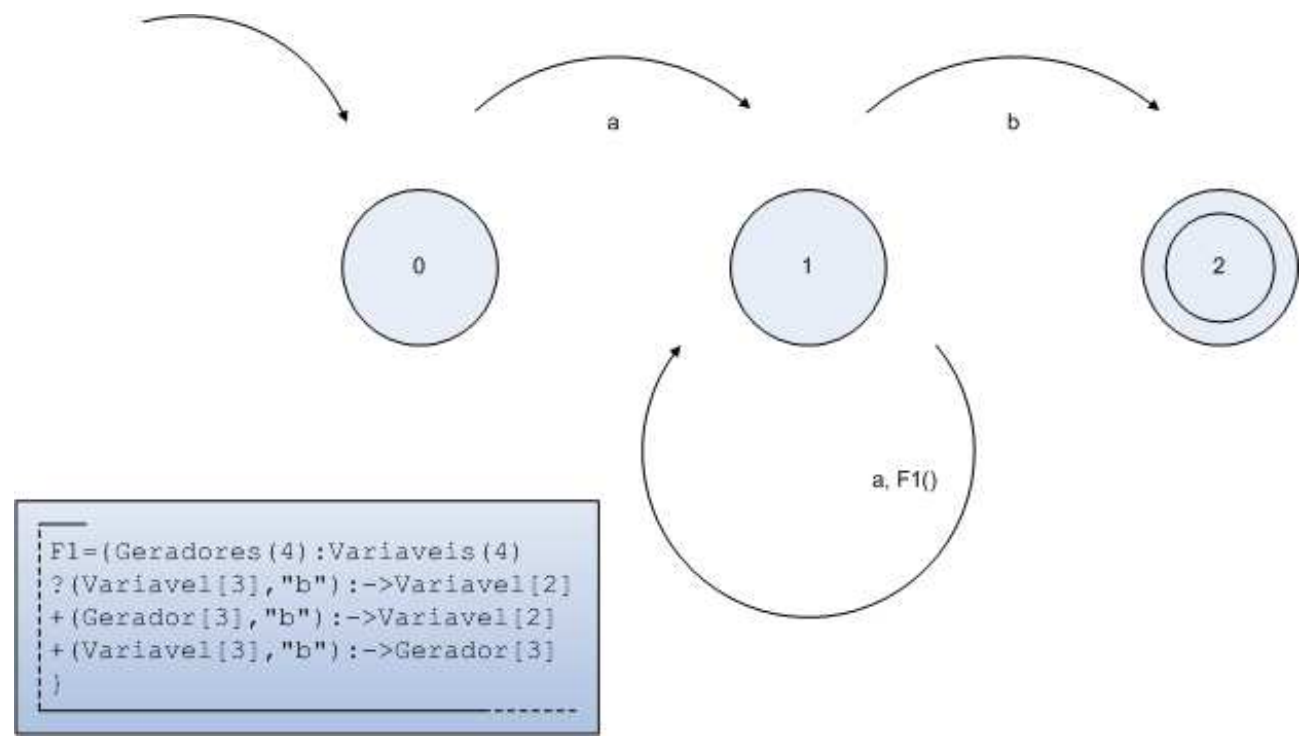

Figura 8.7: Autômato fixo, com a função adaptativa calculada pelo algoritmo.

linguagem em questão. Nesse caso também se acredita que a complexidade do dispositivo a ser inferido ainda era muito grande, apesar da simplificação realizada no modelo.

Autômato sem parâmetros diplóide : A codificação diplóide visa obter maior diversidade no algoritmo, conforme apresentado na seção 6.1.9. Assim, optou-se por testar a inferência do autômato adaptativo com esse mecanismo, para verificar se a diversidade obtida com ele seria suficiente para obter um resultado satisfatório, mas também não foi possível.

Autômato fixo : Por último, ainda na tentativa de simplificar o modelo, foi fixado um autômato, deixando apenas a função adaptativa, sem parâmetros para ser inferida pelo algoritmo. Nesse caso, o algoritmo conseguiu inferir a função que permite que o autômato aceite a linguagem. O autômato está representado na figura 8.7 .

\subsection{Coevolução}

A técnica de coevolução não foi utilizada na inferência de autômatos adaptativos. Essa técnica é útil quando se deseja refinar algum resultado já obtido, através da geração de cadeias mais desafiadoras, que forcem o algoritmo a evoluir, aumentando a freqüência de cadeias que os autômatos aceitaram de maneira eficiente, conforme apresentado na seção 5.11 .

O algoritmo genético para a inferência de autômatos adaptativos não consegue 
encontrar soluções, mesmo que pouco eficientes. Assim, não faz sentido, nessa fase da pesquisa, pensar em dificultar ainda mais o conjunto de testes.

\subsubsection{Conclusões parciais}

Os resultados obtidos não foram satisfatórios, porém foi possível tirar conclusões bastante pertinentes, indicando as possíveis causas do baixo desempenho do algoritmo.

Acredita-se que procurar aperfeiçoar a função de avaliação e alterar a codificação genética, procurando torná-la menos complexa, possa ajudar a obter melhores resultados. Além disso, na seção 9.2 há uma proposta de como melhorar o algoritmo através de uma inferência em dois passos. No primeiro passo o autômato inicial é inferido e no segundo passo a função adaptativa é inferida.

Os resultados ruins obtidos não invalidam a pesquisa ou a arquitetura proposta. Foram pesquisadas a fundo várias características dos autômatos adaptativos e dos algoritmos genéticos, que foram aplicadas na arquitetura proposta. A arquitetura Darwin funcionou de forma muito satisfatória, pois se mostrou bastante flexível, sendo possível realizar vários experimentos com diversas configurações.

Assim, acredita-se que o presente trabalho tenha realizado contribuições importantes, para ambas as áreas pesquisadas, e que servirá de base para pesquisas futuras sobre o assunto. 


\section{Considerações finais}

O objetivo do trabalho era integrar as duas áreas. A abordagem escolhida para realizar essa tarefa foi o de inferir autômatos adaptativos através de algoritmos genéticos. A idéia de procurar inferir um elemento tão complexo teve como objetivo entender melhor as duas tecnologias. Por um lado, foi necessário buscar uma melhor compreensão do que são os algoritmos genéticos e como eles funcionam, por outro, foi necessário entender melhor as estruturas que compõem o autômato adaptativo, como ele funciona e qual o grau de complexidade existente em sua organização interna.

Independentemente dos resultados obtidos, espera-se que a pesquisa realizada tenha trazido contribuições importantes para ambas as áreas estudas nesse trabalho. Também se espera que as pesquisa realizadas possam ser utilizadas como base para futuras pesquisas dentro dessa área, dada a quantidade de sugestões de pesquisas futuras expostas em 9.2.

\subsection{Comentários críticos}

O presente trabalho, apesar das contribuições apresentadas, não foi capaz de obter resultados experimentais satisfatórios na inferência de autômatos adaptativos. Acredita-se que isso se deva, principalmente, ao fato desse dispositivo computacional, o autômato adaptativo, possuir grande complexidade em sua estrutura e execução.

Além da complexidade do autômato adaptativo, o algoritmo não conseguiu obter bons resultados por não ter sido encontrada uma função de avaliação, para autômatos adaptativos, que conseguisse avaliar os autômatos de forma mais gradual, orientando melhor a busca pelo hiperespaço.

Os testes realizados foram bastante restritos, não tendo explorado a enorme quantidade de possibilidades de configurações. O objetivo desse trabalho era iniciar um estudo sobre a integração das duas tecnologias apresentadas. Para 
isso foi realizada uma extensa pesquisa em ambas as áreas. A implementação, que ocorreu em paralelo às pesquisas, visava validar as técnicas estudas e as propostas realizadas no decorrer do trabalho.

Assim, os resultados apresentados foram ilustrativos, que visam demonstrar a qualidade alcançada até o momento pelas pesquisas.

\subsection{Trabalhos futuros}

Durante os testes, foi observada a possibilidade de algumas melhorias que podem vir a trazer resultados mais robustos no futuro. Além disso, foram observadas algumas abordagens diferentes, que podem vir a trazer resultados bastante interessantes. São ela:

1. Cromossomos com tamanho variável: Conforme discutido na seção 5.2, a imutabilidade da codificação dos cromossomos que compõem o genoma dos indivíduos causa limitações na complexidade das soluções, sendo necessária a adoção de várias limitações nas soluções calculadas pelo algoritmo.

Assim, um estudo importante a ser realizado é a elaboração de uma codificação dinâmica dos autômatos, de maneira que o tamanho, quantidade e talvez formato dos cromossomos que compõem o genoma dos indivíduos sejam variáveis.

2. Utilização de gramáticas na geração de cadeias: Da mesma forma que foram utilizadas expressões regulares na geração aleatória de cadeias, podem ser utilizadas gramáticas, de forma que as produções são escolhidas aleatoriamente na formação de uma cadeia pertencente à linguagem.

Com isso, dada uma gramática, seria possível obter um autômato que reconhece a linguagem definida por ela, de forma automática. Além disso, podese estudar uma transformação a ser realizada no conjunto de produções, de maneira que a linguagem utilizada como contra-exemplo também seja gerada automaticamente.

3. Inferência de autômatos em dois passos: Durante os testes com a inferência de autômatos adaptativos, verificou-se que o algoritmo não está conseguindo inferir o autômato e a função adaptativa ao mesmo tempo. Assim, poderia ser proposta uma inferência em dois passos. No primeiro passo um autômato finito intermediário é inferido. Esse autômato aceita uma linguagem semelhante à linguagem alvo, porém, como se trata de um 
autômato finito, a linguagem aceita é regular. No segundo passo, apenas a função adaptativa e as posições onde suas invocações devem ser posicionadas são inferidas.

4. Nova camada adaptativa: Conforme foi observado, a aplicação proposta consegue inferir a função adaptativa para que o autômato aceite uma linguagem. Assim, o autômato, com uma camada adaptativa diferente, ao longo de sua execução, pode submeter as cadeias recebidas a um algoritmo genético, de maneira que este sugira otimizações na camada adaptativa do autômato.

Com isso, é possível que o algoritmo genético funcione como uma terceira camada no autômato, adaptando a camada adaptativa, sugerindo otimizações em função das cadeias recebidas até o momento pelo autômato.

5. Nova camada adaptativa II: A partir de um autômato finito, o algoritmo genético pode calcular modificações nesse autômato, para que esse se adapte a mudanças na linguagem que está processando. Assim, a partir do caminho evolutivo percorrido pelo autômato, a camada adaptativa pode extrair ações adaptativas a serem executadas sobre o autômato, tornando-o apto para as mudanças no ambiente.

Para isso, a camada adaptativa deve realizar um lookahead, recebendo de maneira antecipada os caracteres da linguagem, de forma que o algoritmo genético, em paralelo à execução do autômato, possa evoluir cópias desse autômato, a fim de extrair quais ações adaptativas devem ser realizadas sobre o autômato, para que ele aceite a linguagem.

O funcionamento descrito pode ser executado apenas quando o autômato está operando em "modo de treinamento". Uma vez alcançada a estabilidade, o algoritmo é desabilitado. Como alternativa, o algoritmo proposto pode ser acionado toda a vez que o autômato rejeita algum símbolo recebido da cadeia, assim ele pode propor uma reconfiguração para continuar aceitando a linguagem.

6. Autômatos adaptativos emulando seres vivos: Cada autômato pode ser entendido como uma entidade que simula um ser vivo, que nasce, cresce, se reproduz e morre. Assim, todo o autômato pode ser iniciado com apenas um estado e uma transição adaptativa recursiva. À medida que o autômato recebe elementos da cadeia, ele se adapta e cresce, da mesma maneira que um ser vivo. 
A codificação genética, nesse caso, não irá determinar a estrutura do autômato, mas sua função adaptativa. Assim, o genoma do indivíduo irá determinar como ele deve se desenvolver, assim como carga genética de um ser vivo determina como ele, a partir de um zigoto, deve se desenvolver.

\subsection{Conclusão}

A integração entre as áreas de tecnologia adaptativa e algoritmos genéticos se mostrou um campo bastante fértil para pesquisas, de maneira que uma área tem muito a contribuir para a outra.

A arquitetura Darwin, proposta nesse trabalho, se mostrou muito prática e flexível. Durante as pesquisas foram realizadas várias alterações no aplicativo, de forma que diversas técnicas fossem experimentadas e comparadas. Ainda assim, o código fonte do aplicativo continuou coeso e compreensível. Acredita-se que esse aplicativo venha a ser uma ferramenta bastante útil nas pesquisas futuras, dentro dessa área.

Durante os estudos, os seguintes pontos foram observados:

- O formato do cromossomo possui forte influência sobre o desempenho do algoritmo.

- As funções de avaliação também possuem forte influência sobre o algoritmo, considerar algumas características prematuramente pode inibir a evolução das soluções, principalmente na tentativa de otimizá-las.

- A utilização de contra exemplos é muito importante, principalmente para linguagens mais complexas, com padrões de repetições mais complexos, como no caso das linguagens com aninhamentos sintáticos.

- A aplicação das diversas técnicas discutidas no decorrer do texto proporcionou resultados muito bons na inferência de autômatos finitos.

- Os resultados obtidos com os autômatos adaptativos não foram bons, porém acredita-se que melhorias nas funções de avaliação dos indivíduos e uma diminuição da complexidade na representação cromossômica dos autômatos adaptativos podem contribuir com melhores resultados.

Acredita-se também que o presente trabalho cumpriu seus objetivos: a inferência de autômatos finitos e adaptativos foi realizada. Com isso, foi obtido um 
entendimento melhor de como as duas tecnologias em questão podem ser combinadas. O assunto não foi esgotado. Há diversos experimentos a serem feitos, porém acredita-se que as pesquisas realizadas trouxeram à luz várias possibilidades a serem exploradas, conforme descrito de maneira sucinta na seção 9.2. 


\section{Referências Bibliográficas}

ANGLUIN, D.; SMITH, C. H. Inductive inference: Theory and methods. ACM Comput. Surv., ACM, New York, NY, USA, v. 15, n. 3, p. 237-269, 1983. ISSN 0360-0300.

BECK. Test Driven Development: By Example. Boston, MA, USA:

Addison-Wesley Longman Publishing Co., Inc., 2002. ISBN 0321146530.

BECK, K.; ANDRES, C. Extreme Programming Explained : Embrace Change (2nd Edition). Addison-Wesley Professional, 2004. Paperback. ISBN 0321278658. Disponível em: <http://www.amazon.ca/exec/obidos/redirect?tag=citeulike0920\&amp;path $=$ ASIN $/ 0321278658>$.

BECK, K.; CUNNINGHAM, W. A laboratory for teaching object oriented thinking. In: OOPSLA '89: Conference proceedings on Object-oriented programming systems, languages and applications. New York, NY, USA: ACM, 1989. p. 1-6. ISBN 0-89791-333-7.

CHOMSKY, N. On certain formal properties of grammars. v. 2, p. 137-167, 1959.

COLLARD, P. et al. Fitness distance correlation, as statistical measure of genetic algorithm difficulty, revisited. In: In Proceedings of the European Conference on Artificial Intelligence. [S.l.]: John Witley and Sons, Ltd, 1998. p. 650-654.

CORMEN, T.; LEISERSON, C.; RIVEST, R. Introduction to Algorithms. Cambridge, MA: The MIT Press, 1990.

CRAIGHURST, R.; MARTIN, W. N. Enhancing ga performance through crossover prohibitions based on ancestry. In: Proceedings of the 6th International Conference on Genetic Algorithms. San Francisco, CA, USA: Morgan Kaufmann Publishers Inc., 1995. p. 130-135. ISBN 1-55860-370-0.

DARWIN, C. On The Origin of Species by Means of Natural Selection, or the Preservation of Favoured Races in the Struggle for Life. London: John Murray, 1859.

DAWKINS, R.; KREBS, J. R. Arms races between and within species. Proceedings of the Royal Society of London B, v. 205, p. 489-511, 1979.

EBERHART, R. C.; SHI, Y.; KENNEDY, J. Swarm Intelligence (The Morgan Kaufmann Series in Artificial Intelligence). Morgan Kaufmann, 2001. Hardcover. ISBN 1558605959. Disponível em: <http://www.amazon.ca/exec/obidos/redirect?tag=citeulike0920\&amp;path $=$ ASIN $/ 1558605959>$. 
ETANER-UYAR, A. S. New operators and dominance scheme for a diploid ga. In: WU, A. S. (Ed.). GECCO 1999: Genetic and Evolutionary Computation Conference, Graduate Student Workshop. [S.l.: s.n.], 1999. p. 350-351. Thesis Advisor: A. Emre Harmanci.

FÁBERA, V.; JANES, V.; JANESOVA, M. Automata construct with genetic algorithm. In: DSD '06: Proceedings of the 9th EUROMICRO Conference on Digital System Design. Washington, DC, USA: IEEE Computer Society, 2006. p. 460-463. ISBN 0-7695-2609-8.

FILHO, J. R.; ALIPPI, C.; TRELEAVEN, P. Genetic algorithm programming environments. In: STENDER, J. (Ed.). Parallel Genetic Algorithms: Theory and Applications. Amsterdam: IOS Press, 1993. p. 65-83. Disponível em: $<$ citeseer.ist.psu.edu/filho94genetic.html $>$.

FOGEL, D. B. Evolutionary Computation: Toward a New Philosophy of Machine Intelligence. Third. Wiley-IEEE Press, 2005. Hardcover.

(IEEE Press Series on Computational Intelligence). ISBN 0471669512.

Disponível em: <http://www.amazon.ca/exec/obidos/redirect?tag=citeulike0920\&amp;path=ASIN $/ 0471669512>$.

FOGEL, L. J.; OWENS, A. J.; WALSH, M. J. Artificial Intelligence through Simulated Evolution. New York, USA: John Wiley, 1966.

FOWLER, M. Refactoring: Improving the Design of Existing Code. Boston, MA, USA: Addison-Wesley, 1999. ISBN 0-201-48567-2.

FREGNI, E. Escalação Híbrida na Solução do Problema de Escalação da Manufatura. Tese (Doutorado) - Escola Politécnica da Universidade de São Paulo, São Paulo, Brasil, 1997.

FRIEDBERG, R. M. A learning machine: Part i. IBM Journal of Research and Development, v. 2(1), p. 2-13, 1958.

FRIEDBERG, R. M.; DUNHAM, B.; NORTH, J. H. A learning machine: Part ii. IBM Journal of Research and Development, v. 3(2), p. 282-287, 1959.

GOLDBERG, D. E. Genetic Algorithms in Search, Optimization, and Machine Learning. 1. ed. [S.l.]: Addison-Wesley Professional, 1989.

HILLIS, W. D. Co-evolving parasites improve simulated evolution as an optimization procedure. In: CNLS '89: Proceedings of the ninth annual international conference of the Center for Nonlinear Studies on Self-organizing, Collective, and Cooperative Phenomena in Natural and Artificial Computing Networks on Emergent computation. Amsterdam, The Netherlands, The Netherlands: North-Holland Publishing Co., 1990. p. 228-234.

HOLLAND, J. H. Adaptation in natural and artificial systems: an introductory analysis with applications to biology, control, and artificial intelligence. University of Michigan Press, 1975. Unknown Binding. ISBN 0472084607. Disponível em: <http://www.amazon.ca/exec/obidos/redirect?tag=citeulike0920\&amp;path $=$ ASIN $/ 0472084607>$.

KIRKPATRICK, S.; GELATT, C. D.; VECCHI, M. P. Optimization by simulated annealing. Science, Number 4598, 13 May 1983, v. 220, 4598, p. 671-680, 1983. Disponível em: <http://citeseer.ist.psu.edu/527057.html>. 
KUCHA, K. Geometry of hyperspace. I. Journal of Mathematical Physics, v. 17, p. 777-791, maio 1976.

LANGDON, W. B.; POLI, R. Foundations of Genetic Programming. Springer, 2002. Hardcover. ISBN 3540424512. Disponível em: <http://www.amazon.ca/exec/obidos/redirect?tag=citeulike0920\&amp;path $=$ ASIN $/ 3540424512>$.

LEWIS, H. R.; PAPADIMITRIOU, C. H. Elements of the Theory of Computation. New York: Prentice-Hall, 1981.

LOPES, V. D.; ROCHA, R. L. de Azevedo da. Aplicação de autômatos adaptativos na avaliação de autômatos gerados por algoritmos genéticos. In: LABORATÓRIO DE LINGUAGENS E TÉCNICAS ADAPTATIVAS ESCOLA POLITÉCNICA - UNIVERSIDADE DE SÃO PAULO. Segundo workshop de tecnologia adaptativa. São Paulo, Brasil, 2008. p. 14-17.

MITCHELL, M. An introduction to genetic algorithms. Cambridge, Mass., USA: MIT Press, 1996.

MORET, B. M. E.; SHAPIRO, H. D. Algorithms from P to NP (vol. 1): design and efficiency. Redwood City, CA, USA: Benjamin-Cummings Publishing Co., Inc., 1991. ISBN 0-8053-8008-6.

MOSTAFAVI, M. S. A new method in detection of ceramic tiles color defects using genetic c-means algorithm. In: In Proceedings of word academy of science, engineering and technology. Cairo: [s.n.], 2006. v. 17, p. 168-171.

NETO, J. J. Introdução a compilação. [S.l.]: Livros técnicos e científicos editora S.A, 1987.

NETO, J. J. Contribuições à metodologia de construção de compiladores. Tese (Tese de livre docência) - Escola Politécnica da Universidade de São Paulo, 1993.

NETO, J. J. Adaptive rule-driven devices - general formulation and case study. In: Implementation and Application of Automata 6th International Conference. Pretoria, South Africa: Springer-Verlag, 2001. Vol.2494, p. p. 234-250.

OLSSON, B. A host-parasite genetic algorithm for asymmetric tasks. In: ECML '98: Proceedings of the 10th European Conference on Machine Learning. London, UK: Springer-Verlag, 1998. p. 346-351. ISBN 3-540-64417-2.

PAPADIMITRIOU, C. H.; STEIGLITZ, K. Combinatorial Optimization : Algorithms and Complexity. Dover Publications, 1998. Paperback. ISBN 0486402584. Disponível em: <http://www.amazon.ca/exec/obidos/redirect?tag=citeulike0920\&amp;path=ASIN/0486402584>.

PISTORI, H. Tecnologia Adaptativa em Engenharia de Computação: Estado da Arte e Aplicações. Tese (Doutorado) - Escola Politécnica da Universidade de São Paulo, 2003.

PISTORI, H.; MARTINS, P. S.; CASTRO, A. A. Adaptive finite state automata and genetic algorithms: Merging individual adaptation and population evolution. In: Proceed. Int. Conf. on Adaptive and Natural Computing Algorithms ICANNGA 2005. Coimbra, Portugal: [s.n.], 2005. 
POTTER, M. A. The design and analysis of a computational model of cooperative coevolution. Tese (Doutorado) - George Mason University, Fairfax, VA, USA, 1997.

ROCHA, R. L. de Azevedo da; NETO, J. J. Autômato adaptativo, limites e complexidade em comparação com máquina de turing. In: I Congresso de Lógica Aplicada à Tecnologia. São Paulo, SP: [s.n.], 2000. I, p. 33-48.

ROSIN, C. D.; BELEW, R. K. Coevolutionary search among adversaries. Tese (Doutorado) - University of California, La Jolla, CA, USA, 1997.

RUSSELL, S. J.; NORVIG, P. Artificial Intelligence: A Modern Approach. 2nd. ed. Upper Saddle River: Prentice Hall, 2003. (Prentice Hall series in artificial intelligence). ISBN 0130803022.

SCHWEFEL, H.-P. Kybernetische Evolution als Strategie der experimentellen Forschung in der Strömungstechnik. Tese (Dipl.-Ing. Thesis) - Technical University of Berlin, Hermann Föttinger-Institute for Fluid Dynamics, March 1965. 